\title{
24. \\ „KUD KOJE ŽURE BRZI KRACI / \\ A VODE SVI U BESPUĆE“: \\ VLADAN DESNICA U SPLITU OD 1935. \\ DO 1941. GODINE
}

\section{Drago Roksandić}

UDK: 821.163.42Desnica, V.“1935/1941“

Izvorni znanstveni članak

Sažetak: Magazin Sjeverne Dalmacije (1934. - 1935.) - sporo pripremani, a brzo ugašeni časopisni projekt Vladana Desnice - pojavio se i nestao u sjeni oštroga političkog sukoba između njegova oca dr. Uroša Desnice i vladike dalmatinskog dr. Irineja Đorđevića. Njime je u Sjevernoj Dalmaciji u biti bila pripremljena scena za dramu čija će premijera biti u proljeće 1941. godine, a koja će se s donekle različitim postavama te izmjenama i dopunama teksta izvoditi do proljeća 1945. godine. Vladan Desnica nikada nije javno odgovorio na optužbe koje su ga osobno tangirale. Novi uvidi u piščevu ostavštinu svjedoče da je njegova prevoditeljska, književna i glazbena, ali i historiografska djelatnost baš u to doba postala mnogo intenzivnija, a nezadovoljstvo neizbježnošću državne službe veće. Iz njegovih kasnijih iskaza poznato je da je i prve fragmente Proljeća Ivana Galeba napisao 1936. godine. Ovo njegovo djelo bilo je već tada zamišljeno kao književni odgovor kritičarima, ali i mnogo više od toga; zamišljeno je bilo kao radikalno suočavanje sa samim sobom i svojim svijetom. Ovo je razdoblje i privatno presudno u njegovu životu. Oženio se u Splitu 28. travnja 1934. s Ksenijom Carić, a 13. srpnja 1941., isto tako u Splitu, umro mu je otac.

Ključne riječi: Vladan Desnica, Split, 1935. - 1941., književnost, historiografija, umjetnička istina, historijska istina

凹

osobnoj ostavštini Vladana Desnice, u košuljici naslovljenoj „Razni 'curriculum-i vitae' i 'notices sur l'auteur' iz raznih pera", nalazi se svežanj njegovih strojopisnih biobibliografija. ${ }^{1} U$ većini slučajeva teško je reći gdje su one objavljene i tko ih je potpisao. Neke možda nisu ni tiskane. S jednim izuzetkom, zajednički im je prepoznatljivi Desničin autorefleksivni stil, premda samo neke sadrže izričaje u Ich-Form. Izvorno je neupitna, a za ovu priliku najvažnija jednostranična kopija životopisa „D E S N I C A V l a d a n, Urošev“,

1 Osobna ostavština Vladana Desnice (dalje: OOVD), kut. Izdavački ugovori, „Razni 'curriculum-i vitae' i 'notices sur l'auteur' iz raznih pera“. 
koja u gornjem desnom kutu ima njegovom rukom naknadno upisano vrijeme nastanka, „X - 1949“.2 Pisana je u trećem licu jednine sve do pred kraj, koji je formuliran u prvom licu. Sadržava eksplicitnu ocjenu njegove predratne književne djelatnosti pa je vrijedi citirati:

Književnošću se bavi od ranih dana, ali je vrlo malo objavljivao. Kratko vrijeme pred rat poslao je Geci Konu jednu knjigu lirike koja je trebala da bude štampana, a imao je gotovu jednu knjigu novela; obje knjige, uz mnoge druge materijale, propale su mu u toku rata. Za vrijeme okupacije nije objavljivao ništa. Misli da mu od književnih vrsta najviše odgovara novela, eventualno, roman, a piše i liriku i pokoji članak i esej. (...) Od predratnih objavljenih stvari, nekog su spomena vrijedni esejčići o Dositeju i o Mirku Koroliji, novela-skica „Životna staza Jandrije Kutlače“ i nekoliko lirika, objavljeno sve to u Magazinu Sjev[erne] Dalmacije 1934, 1935, koji je i uređivao, te nekoliko prikaza likovnih izložaba i muzičkih priredaba, rasutih po dnevnim listovima. Bavio se prilično prevođenjem sa talijanskog i francuskog, i to lirike, nešto beletrističke proze i filozofskih djela, naročito s područja estetike, ali je od svega toga objavljeno vrlo malo; možda je vrednije spomena jedino nekoliko Croce-ovih Eseja iz estetike /Split, 1938/. Napisao je, po Botićevoj Bijednoj Mari, operni libreto Adelova pjesma, na koji je muziku napisao Ivo Parać. ${ }^{3}-$ Malobrojne stvari objavljene prije rata kritika je primila mahom veoma pohvalno /S[rpski] K[njiževni] G[lasnik], Letopis M[atice] S[rpske], Glasnik prof[esorskog] društva, i dr./ (... $)^{4}$

Iskazi u životopisu podudaraju se s drugima u ovjerenoj „Prijavi dela“ u beogradskom Zavodu za autorsko-pravno posredništvo od 1. kolovoza 1949. $\mathrm{U}$ njoj su registrirani i neobjavljeni radovi: Putovanje sunca (odjeljci: I Strasna ljeta, II Intermezzo, III Zemlje i gradovi), s napomenom „u cijelosti nije izdano“; „Bijedna Mara“ (Adelova pjesma), libreto za operu Ive Paraća, s napomenom „neizdano“; Svetkovina u poljima, knjiga pjesama, „neizdano“; knjiga pripovijedaka („propalo za vrijeme rata“), knjiga eseja („propalo za vrijeme rata“). Registrirani su i neobjavljeni prijevodi: Iz talijanske poezije (Leopardi, Carducci, d'Annunzio i dr.); René Descartes, Discours de la Méthode; Benedetto Croce, Storia d'Europa nel sec. XIX; Tommaso Campanella, La città del sole; Gustave Flaubert, „Un coeur simple“; Pietro Silva, Storia del Medio Evo i Pietro Silva, Storia dell'età moderna. ${ }^{6}$

2 OOVD, kut. Izdavački ugovori, „D E S N I C A V l a d a n, Urošev“. Formulacija „... poslije Oslobođenja šef pravnog otsjeka Ministarstva financija N[arodne] R[epublike] H[rvatske] u Zagrebu, sada se posvetio isključivo književnosti“ uklanja svaku dilemu o vremenu nastanka.

3 Vidjeti: Dušan Marinković, „Sudbina jednog opernog libreta. Marginalije oko autorstva Desničinog libreta za Adelovu pjesmu“, Ljetopis Dvije hiljade sedme (ur. Čedomir Višnjić), Zagreb 2007., 248-277 (ćir.). Prilog: Vladan Desnica (napisao), „Adelova pjesma. Libreto u 3 slike i Epilog po spjevu Luke Botića 'Bijedna Mara' /1930/“, 260277; Dušan Marinković, „Nove spoznaje o Vladanu Desnici“, Ljetopis Dvije hiljade osme (ur. Čedomir Višnjić), Zagreb 2008., 266-284 (ćir.); Ana M. ZeČEvić, „Muzičko stvaralaštvo Vladana Desnice“, Ljetopis Dvije hiljade osme (ur. Čedomir Višnjić), Zagreb 2008., 285-312 (ćir.); Vladan BAJČETA, „Gozba u poljima - fragmenti rekonstrukcije pjesničke knjige Vladana Desnice u rukopisu“, Split i Vladan Desnica 1918. - 1945. Zbornik radova sa znanstvenog skupa Desničini susreti 2015. (ur. Drago Roksandić i Ivana Cvijović Javorina ), Zagreb 2016., 459-482.

4 OOVD, kut. Izdavački ugovori, „D E S N I C A V l a d a n, Urošev“. Godine 1964. izrazio se donekle drugačije: „Prije rata baš 1939/1940. bio sam završio jednu knjigu pjesama i jednu knjigu novela, a imao sam i gotovu knjigu člančića, kritika i tako u rukopisu. I ta knjiga novela mi je trebala da iziđe kod Gece Kona u Beogradu,..."Vidjeti: Jevto M. Milović, „Razgovor s Vladanom Desnicom o umjetničkom stvaranju“, Hotimično iskustvo: diskurzivna proza Vladana Desnice. Knjiga druga (prir. Dušan Marinković), Zagreb 2006., 136.

5 OOVD, kut. Izdavački ugovori, „Prijava dela“.

6 OOVD, kut. Izdavački ugovori, „D E S N I C A V la d a n, Urošev“. „Od stranih jezika govori talijanski i francuski. Boravio je u Francuskoj jednu školsku godinu /1927/, u Italiju je još od djetinjstva češće putovao na kraće vrijeme / oko mjesec dana/ a jedan put je tamo proveo 5-6 mjeseci. Zadnji put bio u inostranstvu 1937, u Italiji /Venecija, Bologna, Firenza/. U inostranstvu nije javno nastupao niti mu je što prevođeno i objavljivano." 
Sudeći prema svim ovim podacima o njegovu radu u 1930-ima, stvarao je mnogo, ali je on sam učinjeno vrednovao - bar javno - s autoironijske distance: „nekog su spomena vrijedni esejčići“, „,novela-skica“, „,nekoliko lirika“, „,nekoliko prikaza“ itd. Slično je ocijenio svoje prijevode: „(...) možda je vrednije spomena jedino nekoliko Croce-ovih Eseja iz estetike /Split, 1938/.“7 Samo jedan rad u ovom životopisu nije relativizirao: „Napisao je, po Botićevoj Bijednoj Mari, operni libreto Adelova pjesma, na koji je muziku napisao Ivo Parać."

Kasnijim izjavama nije olakšao istraživački pristup svome predratnom radu. Dragocjene su stoga one među njima o tome kako je učio književno stvarati pišući novelu za „Priču Politike". Budući da sada znademo da je to bilo nakon što je prestao objavljivati Magazin Sjeverne Dalmacije (1935.), a prije nego što je počeo pisati Proljeća Ivana Galeba (1936.), važnost te neobjavljene i zasad nepoznate novele za razumijevanje Desničina književnog sazrijevanja nesumnjivo je velika. ${ }^{10}$ Historijska istina ipak je bar donekle drugačija.

Ne bi moglo reći da i ranije nije imao potrebu objavljivati svoje radove. Htio je tiskati čak i svoje najranije pjesme. ${ }^{11}$ Kasnije je objavljivao na vlastiti trošak u Magazinu Sjeverne Dalmacije. ${ }^{12}$ Sam je podmirio tiskarske troškove za Croceove Eseje iz estetike. ${ }^{13}$

Godinama je pregovarao o objavljivanju svojih nestalih rukopisa. ${ }^{14}$ Bilo mu je stalo izdavački realizirati i druge prijevode, dakako, ne na vlastiti trošak. Ni u tome nije uspio prije rata - za razliku od poslijeratnih godina, kada je već kao cijenjeni pisac i slobodni umjetnik, objavljivao uistinu zapažene prijevode. ${ }^{15}$

7 Nije samo on bio kritičan prema svojim predratnim prijevodima. Otac Uroš i stric Boško pomno su ih čitali i kada su držali da je potrebno, bili su vrlo oštri kritičari: „Primio sam prevode. Ima mnogo menda naročito u pogledu metra koji je malo gdje tačan. Naročito u alhaičnoj, nema gotovo stiha, gdje nema koja silaba više ili manje od neg treba. Ako budem imao vremena daću im jednu, za te neobaveznu, refadu. Megjutim možeš i ti da ih sam revidiraš. Na štampanje ne znam može li se računati: prvo Karduči je izašao iz mode i u samoj Italiji, drugo ja nemam više nikakve veze sa književnim listovima. Suma na koju reflektiraš, dala bi se lakše zaraditi prevodeći Pitigrilla." (OOVD, kut. Prepiska do 1945. I., Boško Desnica - Vladanu Desnici, Obrovac, 28. ožujka 1935.) Današnjim čitateljima može biti zanimljiva usporedba koju je Boško napravio. "Pitigrilli was the pseudonim Dino Segre, (9 May 1893 - 8 May 1975), an Italian writer who made his living as a journalist and novelist. His most noted novel was Cocaïne (1921), published under his pseudonym and placed on the 'forbidden books' list by the Catholic Church because of his treatment of drug use and sex.” Vidjeti: „Pitigrilli“, Wikipedia (https:/en.wikipedia.org/wiki/Pitigrilli). Autorstvo tog rada jedino mu je u životu osporavano! Vidjeti radove Dušana Marinkovića u bilj. 2.

9 „Prvu novelu namenio sam 'Politici'“ (razgovor vodio: Stevo Ostojić), Hotimično iskustvo: diskurzivna proza Vladana Desnice. Knjiga druga (prir. Dušan Marinković), Zagreb 2006., 105-106. Novela je bila namijenjena podlistku „Priča Politike“, a autor ju je bio naslovio „Zasluženi odmor“.

10 U pismu Boška Vladanu od 14. studenog 1935. stoji: „Vraćam ti, po želji, novelu. Poslušaj me i ovgje: spacetaj je i pošalji Politici: Neće ti pronijeti ime svijetom, jer nije pulpit za novele, ma te buttará qualche centener de dinarelli, che, a eti lumi de luna, no xe da dispezzarse.“ Time se rješava pitanje kada je Vladan Desnica pisao novelu koju na koncu nije poslao za podlistak „Priča Politike“. OOVD, kut. Prepiska do 1945. I.

11 Prvu pjesmu ponudio je Matici hrvatskoj u listopadu 1931. godine. Vidjeti: OOVD, kut. Prepiska do 1945. I., Olinko Delorko - Vladanu Desnici, Zagreb, [?] listopada 1931.

12 Vidjeti: Drago Roksandić, „Vladan Desnica i Magazin Sjeverne Dalmacije: književnik i (ne)moć tradicije“, Vladan Desnica i Split 1920. - 1945. Zbornik radova sa znanstvenog skupa Desničini susreti 2014. (ur. Drago Roksandić i Ivana Cvijović Javorina), Zagreb 2015., 181-234.

13 Vidjeti poglavlje „Desničin povratak Croceu uoči Drugoga svjetskog rata“ ovog priloga.

14 Detaljnije u: Dušan Marinković, „Biografija Vladana Desnice“, Hotimično iskustvo: diskurzivna proza Vladana Desnice. Knjiga druga (prir. Dušan Marinković), Zagreb 2006., 229-230; vidjeti također: Drago Roksandić, „Ratni dani Vladana Desnice“, Intelektualci i rat 1939. - 1947. Zbornik radova s međunarodnog skupa Desničini susreti 2012. (ur. Drago Roksandić i Ivana Cvijović Javorina), sv. 2., Zagreb 2013., 529-555. Vidjeti str. 532-534.

15 Hrvatski prijevod Descatesove Rasprave o metodi objavila je Matica hrvatska 1951. (prijevod Nike Berusa), a Campanellina Grada sunca Zora 1953. (prijevod Ante Šepića). Za Desničinu intelektualnu historiju intrigantno je da je prevodio istovremeno Descartesa i Campanellu! Croceova „Uvodna poglavlja u „Povijest Evrope u XIX. vijeku“ u Desničinu prijevodu objavljeni su nakon njegove smotri u: Benedetto Croce, Književna kritika kao filozofija (izbor i 
Desničini podaci o prijevodima, o naslovima koje je prevodio, a koje je najvjerojatnije sam birao, svjedoče da ga nisu zanimale samo „umjetničke istine“, kako se običavao izraziti. Descartesovo poimanje istine $s$ jedne strane te Campanellino poimanje $s$ druge strane bili su međusobno vrlo različiti i daleko od Desničina shvaćanja pojma istine. Croceovo shvaćanje povijesnosti pojma istine također se razlikovalo od Silvina, a Desnica ih je, prema vlastitom iskazu, obojicu prevodio. Posvećujući se traganjima za „umjetničkom istinom“, očigledno nije osporavao humanistički, bolje rečeno civilizacijski smisao drugih istina:

(...) umjetnost nije način spoznavanja onoga što se spoznaje logičnim putem. To je intuitivna spoznaja i njena je domena potpuno druga. (...) Kao što se u umjetnosti ne traži da demonstrira geografske i druge istine, tako se isto ne traži da ona donosi neke naučne, sociološke ili historijske istine. To se ne saznaje putem umjetnosti, niti se te istine ispoljavaju i usvajaju intuitivnom spoznajom i saopćavaju umjetničkim, estetskim načinom. ${ }^{16}$

Ovaj rad polazi od pretpostavke da je Desnica kasnih 1930-ih godina, tragajući za svojim putevima prema umjetničkim istinama, itekako držao važnim shvatiti režim drugih istina čovjeka o sebi, drugima, svijetu, prirodi itd. S time je u vezi i pretpostavka da je za njega razumijevanje drugih ljudskih istina bilo nužan preduvjet traganja za umjetničkom istinom o istim tim ljudima. Iskustva političkih i kulturnih konflikata koja je stekao uređujući $M S D$, a koja su ga osobno tangirala sve do 1941. godine pa i mnogo duže, radikalizirala su takvo njegovo opredjeljenje. ${ }^{17} \mathrm{U}$ vremenu koje je lapidarno simbolizirala njegova predratna pjesma „Kišobrani (Ošamućeni građani u predvečerje drugog svjetskog rata)“, Vladan Desnica bio je dezangažirani intelektualac, umjetnik agonije građanskog svijeta: „taji se svak pred samim sobom / i smrću duše tijelo brani“.18

prijevod Vladan Desnica), Zagreb 2004., 129-279. Upoznavši Desničin izbor i prijevod Croceovih Eseja iz estetike, Bogdan Radica ga je podržao u namjeri da prevede i Croceovu Storia d'Europa nel sec. XIX. Vidjeti Prilog II. Čitajući pismo Bogdana Radice Vladanu Desnici, teško je razumjeti motive koji su Radicu godinama kasnije, u političkoj emigraciji, naveli da o „Desnicama“ napiše: „Porast oportunizma u gradu pripisivao se i priljevu u Split hrvatske zadarske, riječke, tršćanske i istarske inteligencije, koja je uslijed svojeg protu-talijanskog nacionalizma odbijala svako približavanje izrazito hrvatskim akcijama. Ona je gledala sumnjičavo na sve, što je dolazilo iz Zagreba, povezivala se sa srpskim generalima i pukovnicima iz komande mjesta, klanjala se raznim Desnicama, predstavnicima svetosavskog radikalizma, i protivu njih se kod starih Splićana pojavljivala duboka mržnja“. Vidjeti: Bogdan RadicA, Živjeti nedoživjeti, knj. 1: Uspomene hrvatskog intelektualca kroz moralnu i ideološku krizu Zapada, München - Barcelona 1982., 42. To je sve o svim Desnicama, uključujući i Vladana Desnicu, što se može pročitati kod Bogdana Radice.

16 „Razgovor na Književnom petku 26. 10. 1956.“, Hotimično iskustvo: diskurzivna proza Vladana Desnice. Knjiga druga (prir. Dušan Marinković), Zagreb 2006.,, 174. Istom je prilikom sažeo svoje poimanje umjetničke istine: „U umjetnosti je istina autentični, nepatvoreni iskreni izraz umjetnikove unutrašnjosti. Ma koliko on objektivnih neistina sadrži, to je po mom mišljenju umjetnička istina. Sve što je u protivnosti s tim nije umjetnička istina."Vidjeti također: Drago Roksandić, „O Vladanu Desnici i 'Desničinim susretima”, Desničini susreti 2005. - 2008. Zbornik radova (ur. Drago Roksandić i Ivana Cvijović Javorina), Zagreb 2010., 255-282. Citat na str. 261.

17 Od „Jedne izjave iz Sjeverne Dalmacije“ (tj. kninske „Usječenjske deklaracije“), objavljene u splitskom Novom dobu 15. rujna 1934. godine, i broširanog „Odgovora na 'Jednu izjavu iz Sjeverne Dalmacije“" Uredništva Glasa Privrednokulturne Matice za Sjevernu Dalmaciju (tj. Plave knjige), tiskanog u Beogradu u prosincu iste godine, pa do zbornika Severna Dalmacija nekad i sad, objavljenog u Beogradu 1939. godine, sukob je bio različitih intenziteta, ali nije jenjavao. Vidjeti: D. Roksandić, „Vladan Desnica i Magazin Sjeverne Dalmacije“, 181-234. U daljnjem tekstu umjesto punog naziva Magazin Sjeverne Dalmacije koristit će se kratica MSD.

18 Vladan Desnica, Zimsko ljetovanje. Pjesme. Ljestve Jakovljeve (= Sabrana djela Vladana Desnice, knj. I), Zagreb 1974., 244. Stihovi iz naslova priloga „Kud koje žure brzi kraci / a svi vode u bespuće“ preuzeti su iz ove pjesme. 


\section{MAGAZIN KAO POLUOTVORENI PROZOR U SVIJET ZNANSTVENIKA}

Koliko god iskustvo s MSD-om za Vladana u štočemu bilo neugodno, toliko ostaci njegove sačuvane uredničke prepiske svjedoče da su ga neki suradnici koje osobno nije poznavao uistinu cijenili. Bilo je i onih koji su željeli pobliže se upoznati i razgovarati s njime. Nisu to bili akademski marginalci. Nikolaus van der Wijk (1880. - 1941.), vodeći nizozemski slavist svog vremena, istraživao je u manastiru Krki i, na Desničinu molbu, u MSD-u objavio stručni izvještaj o tome. Kasnije su njih dvojica razmijenila nekoliko poruka jer je van der Wijk doslovno bdio nad egzaktnošću crkvenostaroslavenskih citata u svom radu. U posljednjoj sačuvanoj iz srpnja 1935. van der Wijk mu je najavio svoj posjet Puli iduće godine i izrazio želju da ga nekom sljedećom prilikom posjeti. ${ }^{19}$

Ako je van der Wijkova reakcija i mogla biti kurtoazne naravi, interes Gerhardta Gesemanna (1888. - 1948.), jednog od vodećih međuratnih slavista u svijetu, poznatog već nakon kritičkog izdanja Erlangenskog rukopisa (1925.), bio je dublje motiviran:

Vrlo poštovani gospodine kolega, danas sam primio II. (...) knjigu „Magazina“. Mnogo sam naučio. Nova je knjiga lepa i korisna. Doneću referat, a o mislima u članku od Rizmondo-a govoriću nešto opširnije. U proleće ću Vas sigurno posetiti. / Srdačno Vaš odani / Gerh[hart] Geseman ${ }^{20}$

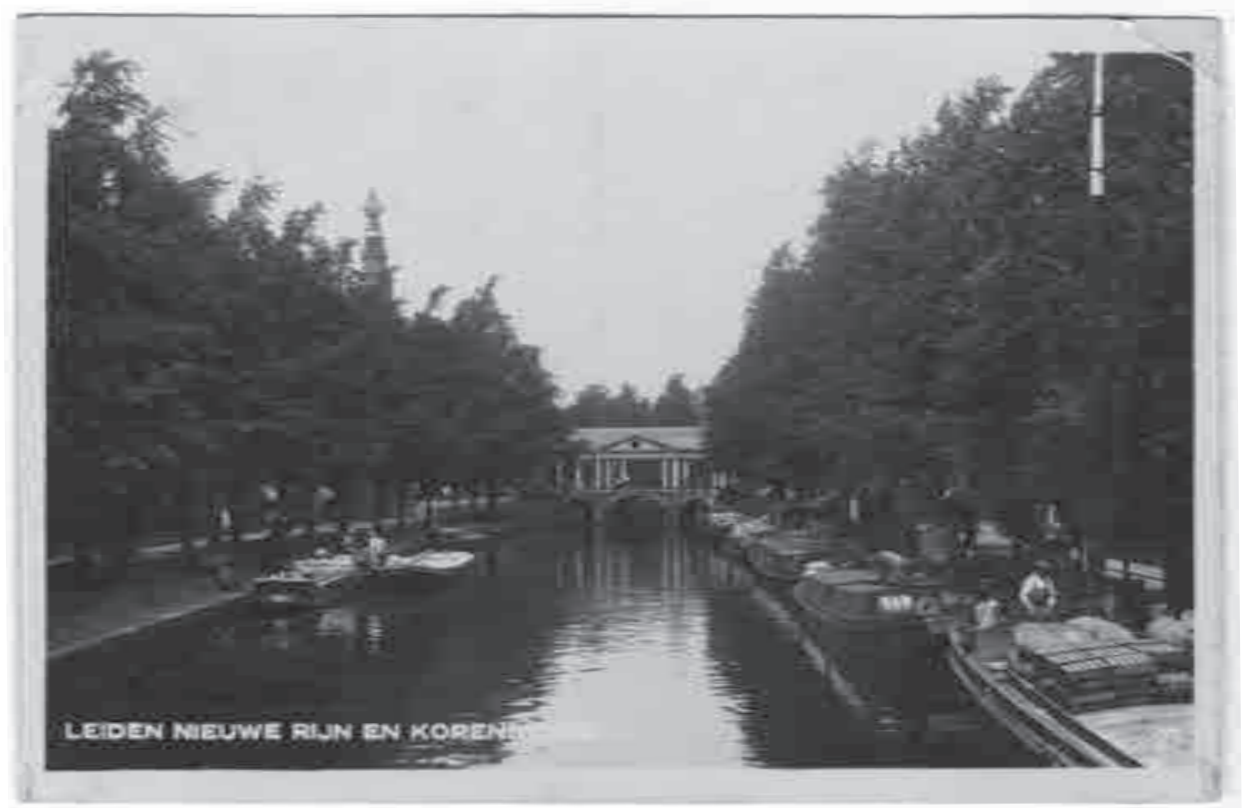

Sl. 1. Sveučilišna knjižnica u Leidenu drži i danas Magazin Sjeverne Dalmacije

19 OOVD, kut. Prepiska do 1945., I., Nikolaus van der Wijk - Vladanu Desnici, Leiden, 24. srpnja 1935.

20 OOVD, kut. Prepiska do 1945., I., Gerhardt Gesemann - Vladanu Desnici, Prag, 14. studenog 1935. (ćir.). 
Iz slavističkog se svijeta s nešto oklijevanja javio i Umberto Urbani, i to kako da mu se zahvali na $M S D$-u tako i da ga obavijesti da će u Zadru „domala izaći II sv[ezak]“ njegovih "Jug[oslavenskih] pisaca“. ${ }^{21}$ Zasad nema podataka o tome jesu li se van der Wijk ili Gesemann kasnije doista i sreli s Desnicom, je li Gesemann pisao o $M S D$-u i dalmatinizmu, ali su takve reakcije, naročito kada su dolazile sa strane, morale izazivati barem trenutačne zadovoljštine kod urednika zasićenog neugodnim iskustvima.

MSD je Desnici otvorio i vrata kod Dinka Tomašića (1902. - 1975.), od 1935. predstojnika prve sociološke katedre u Hrvatskoj, Katedre za sociologiju i statistiku Pravnog fakulteta u Zagrebu. Vladanu je sigurno bio poznat kao čovjek koji je polemizirao s Jovanom Cvijićem, ali i s mnogima na hrvatskoj strani te kao čovjek s ljevice Hrvatske seljačke stranke. U razmjerno kratkom vremenu do 1940., kada je emigrirao u SAD, napisao je nekoliko djela koja su danas u temeljima hrvatske sociologije. ${ }^{22}$ Takav Tomašić privukao je Desničinu pozornost pa mu je poslao oba sveska $M S D$-a. Sačuvane su dvije Tomašićeve poruke Desnici, koje svjedoče o Desničinu eksplicitnom interesu za sociologiju kao znanost te Tomašićeve studije, ali i o Tomašićevu interesu za Desnicu:

Poslao sam Vam jedan primjerak „Pleme i plemenska kultura“, više nisam mogao, a članak o „Predmetu i metodu sociologije“ nisam u opće dao da se odštampaju separati. Zahvaljujem na interesiranju koje pokazujete za moje radove. Nadam se da će mi biti moguće doći u Dalmaciju ovo ljeto i da ću Vas vidjeti. ${ }^{23}$

Slično je reagirao i Nikola Banašević (1895. - 1992.) sa skopskoga Filozofskog fakulteta, jedan od nekoliko vodećih srpskih romanista i slavista tog doba, s očitim uvažavanjem sadržaja primljenih svezaka:

Najlepše Vam zahvaljujem na poslatim sveskama „Magazina Sjeverne Dalmacije“, za koji sam se odmah ubedio da sadrže puno dobrih stvari. Žalim samo što Vam ne mogu poslati svoju knjigu o M[arku] Kraljeviću, jer sam razdao sve svoje primerke. Poradiću kod Skopskog Naučnog Društva, koje je izdalo knjigu, da Vam pošlje nju i koju drugu svoju publikaciju u zamenu. ${ }^{24}$

Ozbiljno su ga shvatili i u Zgodovinskom društvu iz Maribora. Njihov Časopis za zgodovino in narodopisje - koji je počeo izlaziti 1904., a izlazi i danas - od početka se razvijao i kao glasilo za regionalne studije. Stoga je pojava $M S D$-a u Mariboru bila dočekana ne samo s razumijevanjem, nego i kao pojava potencijalno partnerske publikacije te je odmah bila predložena redovita razmjena izdanja. ${ }^{25}$

21 OOVD, kut. Prepiska do 1945., I., Umberto Urbani - Vladanu Desnici, Trst, 15. rujna 1935. Urbani je 1935. objavio dvije jugoslavističke knjige, jednu publicističke, a drugu slavističke naravi: La Jugoslavia e $i$ suoi banati (Trieste, 1935.) i Scrittori Jugoslavi, sv. 2 (Zara, 1935.).

22 Vidjeti: „Tomašić, Dinko“, Hrvatska enciklopedija (http://www.enciklopedija.hr/natuknica.aspx?id=61676)

23 OOVD, kut. Prepiska do 1945., I., Dinko Tomašić - Vladanu Desnici, Zagreb, 20. ožujka 1936.

24 OOVD, kut. Prepiska do 1945., I., Nikola Banašević - Vladanu Desnici, Skopje, 10. ožujka 1936. (ćir.).

25 OOVD, kut. Prepiska do 1945., I., Zgodovinsko društvo v Mariboru - Vladanu Desnici, Maribor, 31. siječnja 1936. Desničine bilješke na margini: „2. II. 1936“ i „poslao im oba godišnjaka i uzvratio na pismo. VD“. 


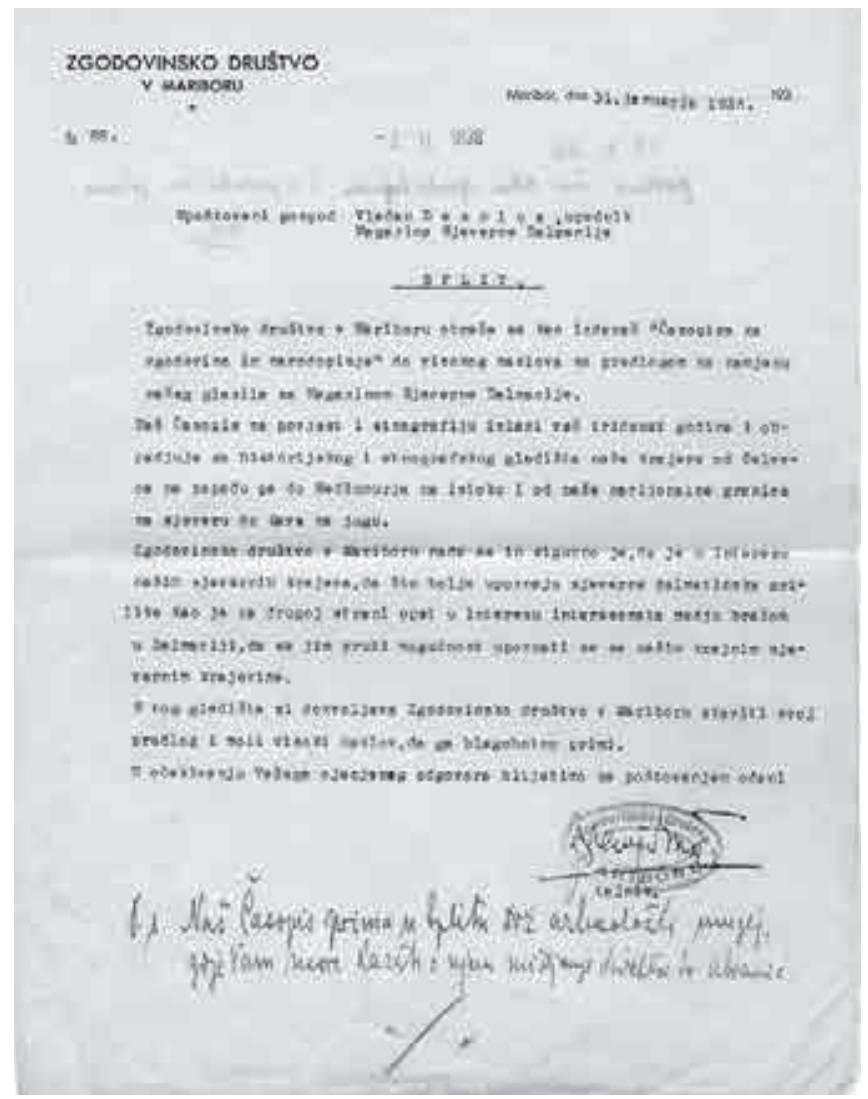

Sl. 2. Zgodovinsko društvo v Mariboru predlaže suradnju Magazinu Sjeverne Dalmacije 1935.

Slično takvo entuzijastično pismo stiglo je i iz redakcije cetinjskih Zapisa. ${ }^{26}$ Bili su to dokazi da je u Kraljevini Jugoslaviji, takvoj kakva je bila, postojala potreba za regionalnim glasilima, otvorenima i tradiciji i modernosti te da ni $M S D$ ipak nije bio shvaćen samo kao refleks instrumentaliziranoga subregionalnog provincijalizma. Iako takve reakcije nisu mogle utjecati na Vladanovu neopozivu odluku o prestanku izlaženja časopisa, mogao ih je nesumnjivo doživjeti kao osobnu uredničku, ali i stvaralačku zadovoljštinu. ${ }^{27}$

Interes za $M S D$ i posebno za pojedine članke u njemu nije nestao sve do pred rat 1941. Riječki župnik monsignor Luigi Torcoletti uložio je 1936. godine nemali napor da dobije $M S D$ iz 1935., očito potaknut saznanjem da je u njemu objavljen članak „Zadranin Šimun Kožičić i njegova štamparija na Rijeci“. 28

26 OOVD, kut. Prepiska do 1945., I., Zapisi: časopis za nauku i književnost, Cetinje - Uredništvu Magazina Sjeverne Dalmacije, Cetinje, 5. svibnja 1936. (ćir.).

27 MSD je Vladana Desnicu učinio poznatim u segmentima različitih stručnih krugova, pa i čovjekom od povjerenja, čovjekom kome se, primjerice, moglo poslati na čitanje vlastite, unikatne primjerke nekih publikacija. Tako mu je Petar Mitropan, urednik Južnog pregleda iz Skopja, slao na posudbu svoj separat neke studije Pere Slijepčevića, ranije objavljene u ovom časopisu. Vidjeti: OOVD, kut. Prepiska do 1945., I., Petar Mitropan - Vladanu Desnici, Skopje, 16. lipnja 1936. (ćir.).

28 OOVD, kut. Prepiska do 1945., I., Monsignor Luigi Torcoletti - Uredništvu Magazina Sjeverne Dalmacije, Rijeka, 24. studenog 1936. Vidjeti: „Adrianskoga mora sirena: digitalna zbirka knjiga o hrvatskoj obali Jadrana“ (http://digitalna.nsk.hr/?object=linked\&c2o=544737). 


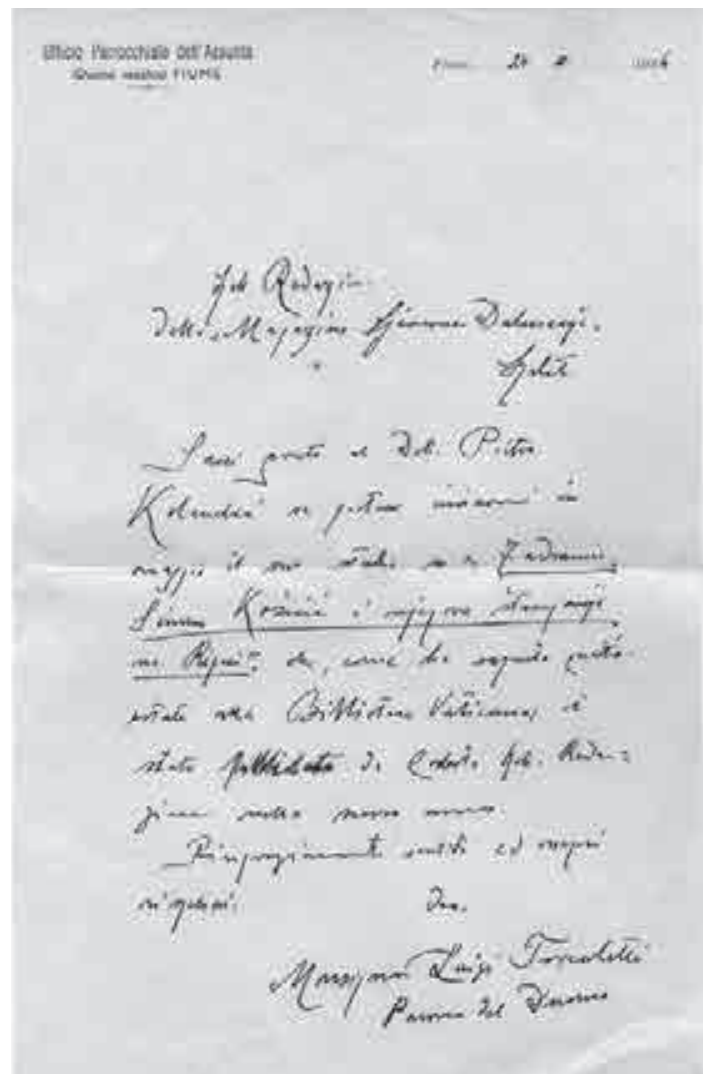

Sl. 3. Riječki župnik Luigi Torcoletti piše Magazinu Sjeverne Dalmacije 1935.
Splitski „pešadiski kapetan II klase“ Krešimir P. Polić javio mu se 27. siječnja 1937. s molbom da mu posudi MSD 1935. zbog članka o malariji u sjevernoj Dalmaciji, koji mu je službeno bio neophodno potreban:

U jednoj od tih revija izašao je jednom članak u kojem se opširno govori o malaričnom problemu u severnoj Dalmaciji.

I ta revija mi je jako potrebna, jer radimo jedan elaborat po ovom pitanju, pa bi taj članak mogli lepo da iskoristimo. Ili tačnije, bez njega ne bi mogli ništa uraditi.

Ovu reviju bih bio slobodan zadržati do konca meseca. U koliko je Vama ona potrebna, ja bi članak odmah prepisao, pa Vam je još u toku sutrašnjeg dana povratio. $^{29}$

Posljednje takvo sačuvano pismo stiglo je od dr. O. Ante Crnice (1898. - 1969.), profesora kanonskog prava na makarskoj bogosloviji, koji je bio u maloj potrazi, izgleda, za esejom Vladana Desnice o Dositeju Obradoviću:

$\mathrm{P}$ [ošt $]$ o[vani] Gospodine!

Najljepša Vam hvala na poslanim obavijestima. Glavno mi je bilo znati, na kojim je stranicama štampan dotični članak u „Magazinu sjeverne Dalmacije“, jer mi je broj „Glasa“ poslao g[ospodin] odvjetnik iz Obrovca.

Od srca zahvaljujem na usluzi i jednako pozdravljam, odani

\section{Dr. O. Ante Crnica ${ }^{30}$}

Naime, jedini tekst koji je bio objavljen i u Glasu i u MSD-u bio je spomenuti Desničin esej „Jedan pogled na ličnost Dositejevu“. Fra Crnica se prethodno bio obratio Bošku Desnici („odvjetnik iz Obrovca“), koji ga je uputio na Vladana.

Koliko god ovih nekoliko primjera recepcije $M S D$-a bilo nedovoljno za bilo kakvo uopćavanje, oni su pouzdano svjedočanstvo da je kapilarna cirkulacija časopisa postojala i da je MSD bio prepoznat i kao regionalna revija i kao publikacija koja „sadrži puno dobrih stvari“ (N. Banašević), i za koju se moglo reći - nakon čitanja sadržaja obaju svezaka: „Mnogo sam naučio" (Gesemann).

\footnotetext{
29 OOVD, kut. Prepiska do 1945., I., Krešimir P. Polić - Vladanu U. Desnici, Split, 24. siječnja 1937. (ćir.).

30 OOVD, kut. Prepiska do 1945., I., Dr. O. Ante Crnica - Vladanu Desnici, Makarska, 12. ožujka 1937.
} 
Koliko god mu sva spomenuta priznanja i interesi za MSD mogli predstavljati zadovoljštine, teško da je mogao ostati ravnodušan prema kratko i jasno postavljenom pitanju Jakova Gotovca, s kojim se - sudeći prema tonu kompozitorova pisma - dobro poznavao (vjerojatno već iz Šibenika, u Vladanovo gimnazijsko doba), a koji mu je uz vijest da mu je dogovorio dragocjenu suradnju muzikologa Dragana Plamenca u MSD-u 1935., pripomenuo:

Veseli me da je pokrenut od Vas ovaj književni „magazin“, ali ne razumijem zašto samo za sjevernu Dalmaciju? Zar nismo mi "mediteranci“ i ovako premaleni da bi se još dijelili u sjeverne, južne, pak čak i u - srednje?! ${ }^{31}$

Desnica je već tada bio došao na glas kao jedan od splitskih kročeanskih „mediteranaca“ pa ga je pitanje i dodatno moglo tangirati jer mu je najvjerojatnije više puta bilo postavljeno, barem u Splitu. Budući da je Gotovac upravo u to vrijeme, s puno samopouzdanja, finalizirao svoju operu Ero s onoga svijeta, možda je imao na umu vlastiti ključ za njezino kulturološko mediteranističko dekodiranje. ${ }^{32}$ Godinama kasnije, Vladan Desnica distancirat će se eksplicitno od regionalno konotirane književnosti: „Dalmacija i Mediteran i mediteransko podneblje su jako uticali na mene. O tom nema govora. I čitav bih ja bio sasvim drukčiji da nisam na tom području odrastao i rođen tu..."33 Dakako, riječ je o podneblju, a ne o samoj njegovoj književnosti kao „regionalnoj književnosti“, koju je odbijao, čak i ako nije uvijek u tome umio biti dosljedan:

(...) moje tzv. „regionalne“ stvari uzeo sam da pišem u jednoj kasnijoj fazi, po nagovoru i na uvjeravanje da „tako treba“, bezmalo da je to „patriotska dužnost“. Sto ćete. Katkad smo naivni. I uprav neobjašnjivo povodljivi. ${ }^{34}$

S druge strane, sigurno nije bio ravnodušan ni prema pismu Dušana Korolije, brata preminulog Mirka Korolije, kojemu se kao urednik $M S D$-a 1935. odužio ne samo znalački i nadahnuto napisanim esejom nego i objavljivanjem vrlo zahtjevne rekonstrukcije Korolijine nezavršene drame Zoe Porfirogenita, dramski poem I čin. Znajući da je Vladan Desnica pjesnički vrlo daleko od njegova brata Mirka, Dušan je prepoznao u Desničinu aktu napor da se Mirkov opus spasi od zaborava kao baština subregionalnog, sjevernodalmatinskog podrijetla:

Vašu studiju o Mirku pročitao sam sa zadovoljstvom. Ima u njoj vrlo tačnih opservacija. Istinu o Mirku mogao je najbolje da uoči i istakne jedan drugi Bukovčanac, jer mu je taj najbliži, najsrodniji. Nema sumnje Vaša je odlična studija dragocjen prilog za proučavanje Mirkove pjesničke individualnosti, pa će ona, bez sumnje, biti uvažena u književnim krugovima.

31 OOVD, kut. Prepiska do 1945., I., Jakov Gotovac - Vladanu Desnici, Zagreb, 28. siječnja 1935.

32 „.... Ero će 'na daske' prvih dana mjeseca maja. - Mogu Vam već sada kazati da sam neobično zadovoljan sa ovim mojim djelom, jer je stilski izjednačeno i 'zdravo' narodsko. Nadam se značajnom uspjehu." OOVD, kut. Prepiska do 1945., I., Jakov Gotovac - Vladanu Desnici, Zagreb, 28. siječnja 1935.

33 J. M. Milović, „Razgovor s Vladanom Desnicom o umjetničkom stvaranju“, 125.

34 Vlatko Pavletrć, „'Svako djelo vrijedi tačno onoliko koliko poetskog sadrži u sebi'“, Hotimično iskustvo: diskurzivna proza Vladana Desnice. Knjiga druga (prir. Dušan Marinković), Zagreb 2006., 71. Vidjeti i: Drago Roksandić, „Književnik, književni opus i mogućnosti historiografskih interpretacija. Pokušaj 'egohistorije' Vladana Desnice“, Književna republika, 4/2006., br. 3-4, 13-24. Citat sa str. 19. 
Znam koliko ste imali truda oko redigovanja Zoje. Vidio sam i sâm koliko je u rukopisu varijanti. Trebalo je dosta umješnosti i strpljenja da se sve probere i poveže. S moje strane ne mogu nego da Vam od sveg srca zahvalim na Vašem trudu i uopće oko cijele opreme. Iz svega Vašeg nastojanja da se Mirko što dostojnije prikaže u Magazinu izbija Vaša ljubav i poštovanje prema našem sirotom Mirku. (...)

Dobro ste učinili što niste štampali ostale Mirkove pjesme. Nije nikakovo čudo što su one ispod prosječne vrijednosti. Mirko je zadnjih godina bio mnogo bolestan pa se je to moralo da odrazi na njegov rad. Zadnje godine nije mogao ništa da radi. ${ }^{35}$

Budući da zasad ništa ne znamo o sadržaju Desničine nestale predratne zbirke eseja („propalo za vrijeme rata"), bespredmetno je pretpostavljati je li nakon MSD-a napisao ijedan esej posvećen stvaralaštvu bilo kojega drugog sjevernodalmatinskog pisca. Stric Boško ga je češće poticao da piše o Simi Matavulju, kojeg je i Vladan cijenio kao književnika, ali se i o tome može vrlo malo reći:

(...) to sam ti ja rekao čim sam prvi put pročitao Dositeja: u tom je žanru tvoj pravi i veliki dar. Ako hoćeš da me poslušaš izradi jedan veliki esej o Matavulju i pošalji ga meni pa ću se ja postarati za dostojan plasman. ${ }^{36}$

Ova Boškova želja ostala je očito neuslišena. Sve češće ga je književno usmjeravao pravcima kojima se Vladan nerado kretao ili se više nije ni htio kretati. Prividno je paradoksalno da je istovremeno Vladan poticao strica da se vrati svojim historiografskim studijama, žanru u kojem je, prema Vladanovu mišljenju, bio njegov pravi i veliki dar. U tome je bio uspješniji, dijelom i zato što se i on sâm aktivno zanimao za historiografiju u širokom rasponu od regionalne do svjetske, a dijelom i zato što je Boško češće uvažavao Vladanova mišljenja i umio surađivati s njime.

\section{IN PATRIMONIO: ĆAĆA UROŠ, BARBA BOŠKO I VLADAN}

Time se vraćamo na problematiku o kojoj su s Vladanom Desnicom raspravljali i njegovi suvremenici te koja ne prestaje biti prijeporna u povijesti književnosti. Proljeća Ivana Galeba doživljavalo se pa i doživljava kao autobiografski roman. ${ }^{37}$ Budući da ga je Desnica prema vlastitom iskazu počeo pisati 1936. godine - dakle, u vrijeme koje je u fokusu ovog priloga - bitno je njegovo mišljenje o tom pitanju: „(...) autobiografsko je u onoj mjeri u kojoj je svako naše djelo, makar o marsijancima pisali, autobiografsko. (...) Uvijek uzimamo sebe za model, znate, i uvijek pišemo autobiografski. “38 Ovo stajalište dodatno je

35 OOVD, kut. Prepiska do 1945., I., Dušan Korolija - Vladanu Desnici, Kistanje, 5. kolovoza 1935. (ćir.).

36 OOVD, kut. Prepiska do 1945., I., Boško Desnica - Vladanu Desnici, Obrovac, 14. studenog 1935.

37 V. PAvletić, ,'Svako djelo vrijedi tačno onoliko koliko poetskog sadrži u sebi'“, 69; J. M. MiLović, „Razgovor s Vladanom Desnicom o umjetničkom stvaranju“, 122-123. Problem je i dalje aktualan. Na Desničinim susretima 2016. u Beogradu, od 23. do 25. rujna t. g., Luca Vaglio govorit će o temi „Iskustva pseudoautobiografskog romana 20. stoljeća: Italo Svevo i Vladan Desnica."

38 J. M. Mılović, „Razgovor s Vladanom Desnicom o umjetničkom stvaranju“, 122-123. Jednom prilikom Vladan Desnica je takvu mogućnost interpretacije sam potvrdio: „A ‘Proljeća Ivana Galeba' jedna je lirsko-psihološko-meditativna proza, skroz subjektivna i intimna, roman jednog krajnjeg individualiste, tipičnog pretstavnika onog tipa 
zaoštrio očitujući se o relativnoj važnosti „učitelja“: „Čini mi se da u svakom književnom (poetskom) djelu bar 80 posto njegove poetske suštine potiče ili nekako vuče svoj korijen iz djetinjstva. “39 Sravnjivanjem Desničine izjave o učenju od mnogobrojnih „učitelja“ s ovom o djetinjoj „poetskoj suštini“ svakoga piščeva opusa, temeljno pitanje o piščevoj „personalnosti“ u Desničinu slučaju postaje još složenijim, pa i otvorenijim, tim više što je i njegovo djetinjstvo „doba učitelja“, i to najutjecajnijih, obiteljskih:

Otac mi je bio čovjek velike kulture, ne samo opće nego i literarne specijalno, i vrlo istančanog ukusa, odličan stilista i tako. U familiji se uopće to gajilo i čak četiri ili pet generacija unatrag ima tragova da su imali toga crva, toga crva pisanja, da tako kažem. I tako čitava me ta sredina (...) Stric je isto bio vrlo kulturan čovjek sa smislom za literaturu; prevodio je; čak je prevodio nešto Matavulja na talijanski. Literatura, historija, povijest umjetnosti i filozofija, ali u prvom redu literatura, nekako je bilo in patrimonio kod mene u obitelji i od najranijih godina sam na to upućen. ${ }^{40}$

Bile su to riječi izrečene 1964., u posljednjim godinama njegova života. Krug se očigledno zatvorio jer su djetinja poetika i djetinji učitelji tada već bili jedva međusobno razlučivi. Međutim, nakon iskustva s $M S D$-om, dakle u vrijeme kada je počeo pisati Proljeća Ivana Galeba, 1935./1936., odnos prema ocu i stricu, Ćaći i Barbi, Urošu i Bošku bio je uvelike drugačiji. ${ }^{41}$

Kada je o ocu riječ, kriza međusobnog povjerenja potječe iz vremena kada je nakon završene šibenske gimnazije 1924. godine - tj. izmještene zadarske hrvatske gimnazije - trebalo donijeti odluku o izboru i mjestu sveučilišnog studija. Sigurno je da studij prava nije bio njegov željeni izbor, već očev i stričev, koji su i sami bili pravnici. ${ }^{42}$ Upitno je i gdje je po očevu i stričevu mišljenju trebao studirati. ${ }^{43}$ Budući da je Kraljevina Srba, Hrvata i Slo-

intelektualca koji pretstavlja poslednji kasni cvet građanske intelektualne klime." Vidjeti: M[iodrag] BuLAtović, „Jedan trenutak sa Vladanom Desnicom“, Hotimično iskustvo: diskurzivna proza Vladana Desnice. Knjiga druga (prir. Dušan Marinković), Zagreb 2006., 45.

39 Grozdana Olujıć, „Pjesnik tuge i nade. Razgovor s Vladanom Desnicom“, Hotimično iskustvo: diskurzivna proza Vladana Desnice. Knjiga druga (prir. Dušan Marinković), Zagreb 2006., 53.

40 J. M. Milović, „Razgovor s Vladanom Desnicom o umjetničkom stvaranju“, 124; Drago Roksandić, „Boško Desnica - Vladanu Desnici. Izbor pisama iz Osobne ostavštine (1933. - 1938.) Vladana Desnice“, u: Ljetopis Dvijehiljadepetnaeste godine, Zagreb 2015., 374.

41 U sačuvanoj obiteljskoj prepisci Vladana Desnice otac Uroš uvijek je „Ćaća“, a stric Boško „Barba“. Ništa se nije promijenilo ni kada je Vladan ušao u četvrto desetljeće svog života pa ćemo se i u ovom prilogu, gdje god to bude smisleno, koristiti tim imenima kojima su se međusobno oslovljavali. Inače, Uroša je jedino Vladanova supruga, Ksenija rođ. Carić, Hvaranka, u pismima oslovljavala „pape“.

42 „Desnica u svom dečačkom dobu, satima je slušao probe šibenske filharmonije. Godinama je pevao i školovao svoj glas, tenor, u Šibeniku, Zagrebu i Parizu. Muzika ga je tako neodoljivo privlačila da joj se hteo potpuno predati.“Vidjeti: „Između muzike i literature. Razgovor s književnikom Vladanom Desnicom“ (razgovor vodila: Ivanka Bešević), Hotimično iskustvo: diskurzivna proza Vladana Desnice. Knjiga druga (prir. Dušan Marinković), Zagreb 2006., 81. Vidjeti također: „Iako je želio studirati književnost ili povijest umjetnosti, a nije mu bila strana ni daleka pomisao i o studiju muzike, ipak se priklonio mišljenju oca da je bolje izabrati sigurniji profesionalni kruh. (...) U studentsko vrijeme i u Zagrebu i u Parizu često je posjećivao likovne izložbe, muzičke i kazališne predstave. (...) U studentskom periodu (1927) nastaje kompozicija za violinu i klavir Capriccio.“ Detaljnije u: D. Marinković, „Biografija Vladana Desnice“, 224.

43 Stric mu je u studijskim godinama, vjerojatno na samom početku, uputio pismo indikativna sadržaja: „Dragi Vlade! Kad si već tu, nemoj nikako propustiti da pregledaš Kukuljevićevu zbirku starih drvo i bakroreza. Ona se nalazi ili u Akademiji ili u Muzeju. Siguran sam da u njoj ima bakrorezni portret Don S[tipana] Šurića (publikovao ga je, pred mnogo godina, Dom i Svijet) pa je lako da nađeš i štogod za nas važnije. Ako ti nije teško, potraži profesora Većeslava Heneberga (bavi se gradinama, bio je u Obrovcu i ja sam mu bio pri ruci), on je negdje na Muzeju ili Akademiji, pa ga zamoli da ti pomogne. Anzi, mogao bi mu ovom prilikom spomenuti, da ti preda ono nekoliko slika snimljenih sa olovnih crteža Obrovca, što sam mu posudio i što mi još nije vratio." Pismo je inače bilo upućeno na adresu: „Mr. stud. jur. Vladan Desnica / Zagreb / Sveučilišse“. 
venaca u to doba bila europski školski primjer centralizirane države, logično bi bilo da je studij prava upisao u Beogradu, gdje se pravna kultura normirala i verificirala, i to $s$ velikim udjelom profesora s beogradskoga Pravnog fakulteta. Ipak je otišao u Zagreb. Možda je upis studija prava u Zagrebu bio njegov uvjet ocu da ga uopće upiše? Kako je u tim godinama Vladan bio u dvojbi hoće li se u životu posvetiti glazbi ili književnosti, razumljivo je što je preferirao otići u Zagreb, gdje je muzička kultura u to doba bila na višoj razini nego u ratom teško pogođenom Beogradu. ${ }^{44} \mathrm{Na}$ Sveučilištu u Zagrebu nije stekao doktorat, što mu je otac - koji je imao doktorat prava sa Sveučilišta u Beču - sigurno barem intimno zamjerio jer ionako nije imao nikoga tko bi ga mogao zamijeniti u njegovu odvjetničkom uredu u Splitu. Ne stekavši doktorat prava, Vladanove su karijerne perspektive u ishodištu bile ograničenije.

Kriza međusobnog povjerenja između sina i oca ponovno je bila neizbježna nakon neuspjeha s $M S D$-om, tim većeg što se Vladan ponekad mogao osjetiti svojevrsnom sporednom žrtvom političkog sukoba između svog oca i vladike Irineja Đorđevića. ${ }^{45}$ Svoj vrhunac ona je dosegla u ljeto 1935. godine, dakle u vrijeme izlaska iz tiska MSD-a 1935. Tada je Vladan Bošku otvoreno napisao da svoj „životni put“ smatra promašenim. Ovaj ga je savršeno razumio i ohrabrio najviše što je mogao:

Što se tiče tvog nezadovoljstva radi promašenog životnog puta, mogu da ti kažem da se kod tebe ponavlja moj slučaj: i mene je za deset godina grizlo i trovalo nezadovoljstvo i ja sam isto kao i ti krivio i optuživao svoga ćaću. Razlika je samo u tome što ti to činiš sa nešto više prava nego ja, jer su tvoje sposobnosti daleko veće i daleko jače prononsirane nego što su bile moje. Ipak vjeruj che un giorno ti te ricrederà, come che mi me son ricredudo. Prije svega grješiš kad misliš da ti je ta struka zapreka i da radi nje nećeš moći da u punom opsegu valoriziraš mogućnosti koje osjećaš u sebi. Nije istina! Ti si i pored prava i pored ureda i pored Celigoja dao već dosada ne „mizerne člančiće“ već duboke i prvorazredne stvari. Uvjeren sam da bolje ne bi dao ni da si mjesto Benjmog (sic!) agrara, rješavao pitanja komparativne književnosti pred jednom acilom (sic!) kretena i balavaca. Ovako si ti osposobljen za sve i ako nastane potreba (kao što neminovno hoće „quando cresce famiglia“) za većom zaradom ti ćeš zakoračiti u unosnu advokaturu, koja mene nije obogatila jer nisam za nju sposoban a ćaću jer je nezaslužno i neoprostivo na nju pljunuo, ali koja tebi otvara široke mogućnosti uspjeha i zarade jer si i pored tvog koprcanja za nju stvoren. Da ja imam la tua testa quadra vidio bi renomeje i banica! Nemoj dakle da se grižeš, doći će dan kad ćeš baš radi ovog zapaliti lumin ćaćinoj duši, ko što ga i ja danas palim onoj moga ćaće. ${ }^{46}$

Vladan je već sljedeće godine, stavivši na stranu „Životni put Jandrije Kutlače“, počeo pisati, kao što smo podsjetili, Proljeća Ivana Galeba ${ }^{47}$ Ipak, što se više udaljavao od tema $M S D$-a i krizne 1935., to je imao više razumijevanja za sve starijeg, sve bolesnijeg i sve ne-

\footnotetext{
44 Vidjeti: Josip Andreis - Dragotin Cvetro - Stana Đurić-Klajn, Historijski razvoj muzičke kulture u Jugoslaviji, Zagreb 1962., 196-252 i 684-700.

45 Vidjeti bilj. 17.

46 OOVD, kut. Prepiska do 1945. I., Boško Desnica - Vladanu Desnici, Karin [kolovoz 1935.].

47 Drago Roksandić, „...Pisac uvijek ima upravo onoliku slobodu stvaranja koliku sam sebi dozvoli...' Civilna kultura Vladana Desnice poslije 1945. godine“, Desničini susreti 2010. Zbornik radova (ur. Drago Roksandić i Ivana Cvijović Javorina), Zagreb 2011., 24-25. Vidjeti i: Drago Roksandić, „Vladan Desnica, intelektualac danas“, Intelektualac danas. Zbornik radova s mectunarodnog skupa Desničini susreti 2013. (ur. Drago Roksandić i Ivana Cvijović Javorina), Zagreb 2014., 197-209.
} 


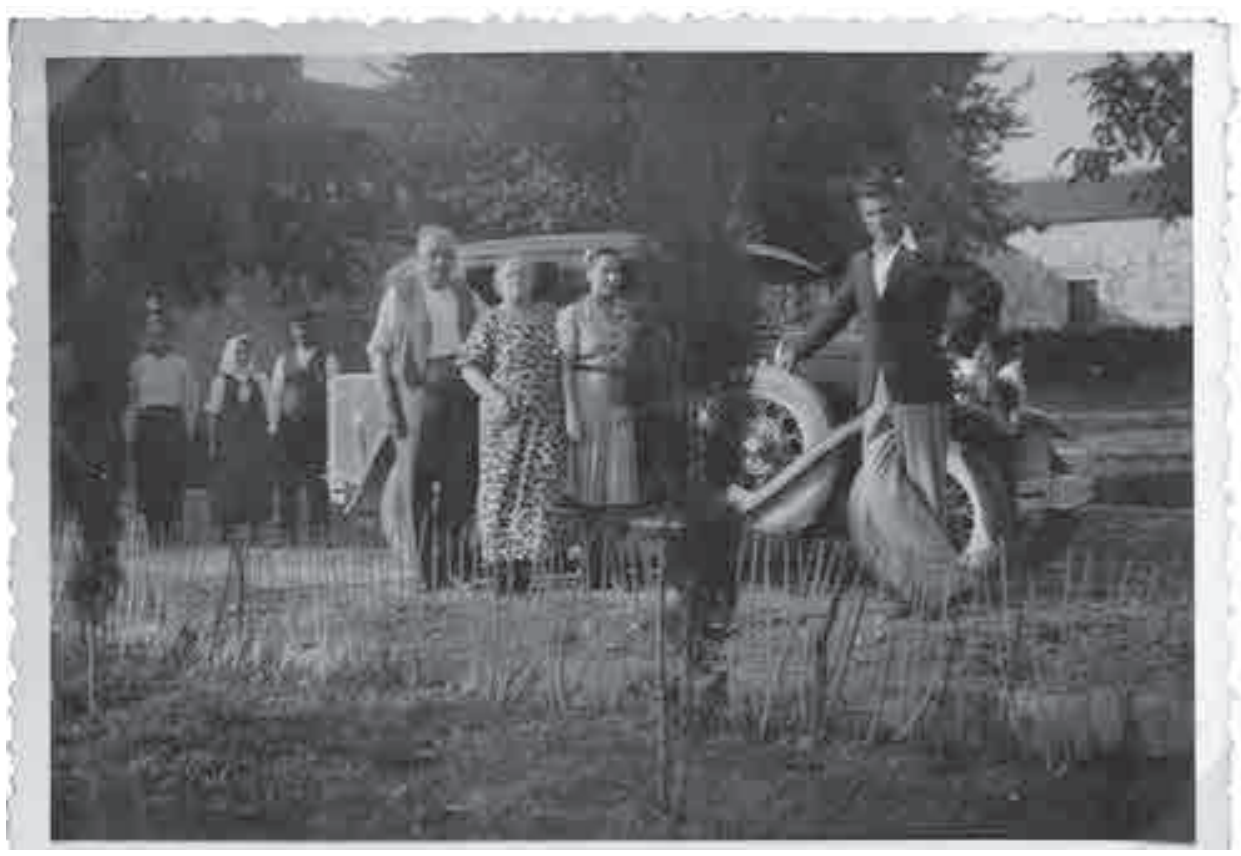

Sl. 4. Ostarjeli i oboljeli Uroš Desnica sa suprugom Fanny i kćerkom Natašom pred Kulom u Islamu Grčkom kasnih 1930-ih

zadovoljnijeg oca, tim većeg što politički (auto)marginalizirani otac ionako više nije mogao biti utjecajniji politički akter. ${ }^{48}$

Njegovo zdravlje naglo se pogoršalo u proljeće 1937. godine, o čemu svjedoči i Uroševo pismo svome dugogodišnjem prijatelju i obiteljskom liječniku dr. Boži Peričiću:

Dragi Doktore! Javljam Vam da je po mišljenju ovdašnjih liječnika moje srce potpuno regenerirano i šećer u krvi sveden na normalu i da sad, kako oni kažu, sva vještina je u tome da se pametno živi kako bi se ovo stanje održalo.

Sve će Vam detaljno pisati Dr Grossman[n].

Ali na žalost zadesila me je druga nezgoda koja je možda manje opasna ali za mene mnogo zanovetnija i bolnija, tojest bol i nemoć u lijevom koljenu koja već traje 15 dana tako da uvijek ležim i ne mogu da se maknem. Pošto su mi uzeli nekoliko Rönt[gen] snimaka i nijesu našli ništa to su zaključili da se radi o upali pokosnice.

Zato nema smisla da više ležim ovd[j]e pa sam odlučio da se povratim kući i gdje ću stići u Neđelju večer u 8 sati. Ali kako nemogu da se maknem to će me iz Sanatorija prenijeti u vagon a u Splitu iz vagona do kuće kočijom.

Nastaje pitanje kako ću se iz kočije popeti do stana, pa Vas zato molim da mi Vi nađete dva bolničara koja će me dočekati pred kućom da me nekako iznesu do drugoga kata da tako bude dovršen prvi dio ove Odiseje.

$\overline{48}$ Vladanu, koji je živio s ocem, nije moglo promaknuti ono što je Barba vidio iz Obrovca. Ovdje je nevažan povod koji ga je potaknuo da kaže: „On [Uroš] ima i znanja i sposobnosti i kulture i stila da može da stupi u to društvo, ali je za tvog ćaću važnije pitanje islamske sluškinje, Krste, Vase Uzelca i t.d. neg svi oni momenti koje ti ističeš. Nek se primi on, a moja svesrdna i anonimna pomoć u pitanjima i d[i]jelovima za koje sam kadar tu je ora e sempre a isto tako i tvoja, koja više znači od moje.“ OOVD, kut. Prepiska do 1945. I., Boško Desnica - Vladanu Desnici, Obrovac, 13. prosinca 1934. 
Pozdrav Vama i Vašima od moje žene. Vas prijateljski pozdravljam i želim što pr[ij]e vidjeti. Dr Desnica ${ }^{49}$

Kada mu je zdravlje ovako naglo oslabjelo, Vladan i Boško pomislili su na najgore i istovremeno otkrili jedan drugom koliko im obojici Uroš znači. Boškovo je pismo snažno svjedočanstvo s time u vezi:

Dragi Vladane! Tvoje i ćaćino pismo prenerazilo me i turilo u drugi red sve moje nevolje. To je za mene udarac po tjemenu kakvog ne pamtim, jer ni ti niti iko ne može da zna što Uroš za mene znači. Kad mi je umrla majka on je meni postao majka a kad mi je umro otac i otac i majka. U prvom impulsu bio sam riješio da dogjem tamo sa prvim vlakom, ali me Pasini i Zorka odvraćaju jer da bi se mogao uzbuditi. Bio sam odlučio, poslije vaših pisama, vratiti se sutra u Obrovac - ali sad sam odlučio ostati. Da te ja ne zovem na telefon, što bi isto moglo da ga alarmira jer je telefon kod stola za kojim sjedi, zovi me ti sutra na telefon oko 10 sati. Ja ću biti u bolnici, pa ako se sporazumijemo da dogjem uhvatiću vlak od 10.30. Još bolje je, ako možeš, da me zovneš u 9 1/2 jer ko zna hoće li se moći dobiti veza. Ti me zovi sa kakvog drugog telefona da on ne zna i zovi bolnicu.

Zbogom mili moj Vlado

Ljubi te / $\mathrm{Barba}^{50}$

Što je otac više postajao vlastita sjena, stric se ustrajnije vraćao svojim mladenačkim povjesničarskim interesima, nastojeći objaviti bar ponešto što će biti trajnije vrijedno, dakako, unutar limitâ u kojima je živio i radio. Vladanovi poticaji i suradnja bili su pritom ponekad i presudni. ${ }^{51}$ Prije Prvoga svjetskog rata stric je vrlo mnogo radio u zadarskom arhivu i napravio mnoštvo ispisa i prijepisa dokumenata iz sjevernodalmatinske povijesti od 16 . do 18. stoljeća. Nerijetko je i kasnije naručivao (i, dakako, plaćao) prijepise iz zadarskog i mletačkog arhiva. ${ }^{52}$ Čitao je vrlo mnogo, gdje god je stigao od Zadra do Beča, gdje je i sam studirao pravo. (Ni on nije doktorirao!) Kasnih 1930-ih Vladan ga je silno podržavao i doslovno pomagao da pripremi za objavljivanje u Srpskoj kraljevskoj akademiji voluminoznu, dvosveščanu zbirku dokumenata Istorija kotarskih uskoka..$^{53}$ Bio je to, uostalom, i za njega još jedan iskorak u historiografiju! ${ }^{54}$

49 OOVD, kut. Uroš Desnica I., Uroš Desnica - Boži Peričiću, 20. svibnja 1937.

50 OOVD, kut Prepiska do 1945. I., Boško Desnica - Vladanu Desnici, 13. travnja 1937.

51 Pritom je i sam Boško bio u sve lošijoj kondiciji: „Ja sam ti pred par dana pao sa zidića na livadi, nauznak na kamenje i satrao se nemilo. Propljuva sam krv i ugruvan sam do Boga. Bole me rebra, prsi, legja, ne mogu da dišem ni da kašljem a kad kinem to je za poluditi. A sve to snosim na nogama jer mi trganje otava i udjence ne dopuštaju da ležem. Jarčeva života i sudbine!" OOVD, kut Prepiska do 1945. I., Boško Desnica - Vladanu Desnici, [Obrovac], "pod konac 1938“.

52 U tom je smislu instruktivan „Predgovor“ u: Boško Desnica, Istorija kotarskih uskoka, sv. 1: 1646-1684, Beograd 1950., 5-6 (ćir.).

53 Boško DesnicA, Istorija kotarskih uskoka, sv. 1: 1646 - 1684, Beograd 1950. (ćir.); sv. 2: 1684-1749, Beograd 1951. (ćir.).

54 Izgleda da je ponekad bio historiografski pretenciozniji nego što je Boško mogao prihvatiti pa se u sačuvanoj prepisci mogu pronaći i tonovi koji inače odudaraju od ugođaja i stila stričevih pisama: „(...) Nikola iz Levanta nije [se] povratio i da je umro prije oca dakle izmegju februara 1686 i augusta 1867. Ti si dakle slabo pročitao godinu na alberu i otuda je nastala tvoja, po mene uvrjedljiva i ponizujuća sumnja, u njegovu tačnost. Kad položiš ispit, vrati se preko Venecije, a ja ću dati akreditive na ljude, koji će ti pomoći da ovo, kao i mnoga druga još neobjašnjena pitanja, izvedeš na čistac." Vidjeti: OOVD, kut. Prepiska do 1945. I., Boško Desnica - Vladanu Desnici, Obrovac, 28. ožujka 1935. Napominjemo da je sačuvan samo ulomak ovog pisma. „Vladan Desnica i Istorija kotarskih uskoka Boška Desnice“ bit će predmet našeg priopćenja na Desničinim susretima 2016. 
Nakon što se oženio (1934.) i zaključio svoju uredničku avanturu u MSD-u (1935.) te započeo, pored ostalog, pisati Povrata Ivana Galeba (1936.), Vladan Desnica se književno sve više udaljavao od mnogo toga što je naslijedio in patrimonio od oca i strica. Istovremeno se sve više brinuo kako za vlastitu obitelj tako i za onemoćale roditelje, posebno oca, a donekle i za strica. Posebno su ga intrigirale stričeve historiografske preokupacije u vezi s ranonovovjekovnom poviješću dalmatinskog Sjevera, tim više što je stric desetljećima prikupljao izvorno arhivsko gradivo prije svega u Zadru i Veneciji. Dokumentarna demitologizacija ravnokotarske uskočke povijesti, oslobađanje od balasta dinarske (pseudo)romantičarske heroike bila je i za njega jedna od bitnih pretpostavki za vlastito umjetničko sazrijevanje, za književno suočavanje sa svojim vremenom.

Krećući se u širokim rasponima od prevođenja Croceovih i Silvinih historiografskih radova do aktivnog asistiranja Bošku u pripremi njegovih radova za objavljivanje, i sve to na marginama vlastitog književnog rada i studija iz estetike, Vladan nije bio gluh i slijep pred kapilarnim rastakanjem društva s kojim je osobno bio identificiran i spram kojeg se istovremeno osjećao trajno distanciranim, kao i promjenama u svijetu koje čovjeku poput njega nisu davale nade. Europsko „vrijeme netrpeljivih“ kasnih 1930-ih godina nije ga poticalo da i sam postane javno angažiran za vlastito poimanje ljudskih vrijednosti. Umjetničke istine tim su više bile jedine u kojima je mogao nalaziti smisao vlastitog života. U takvim raspoloženjima pisao je Proljeća Ivana Galeba, ali varirao i druge književne vrste, među kojima i pjesničke, izražavajući stihovima - pored ostalog - vlastiti osjećaj bespomoćnosti i krhkosti ljudske egzistencije uoči početka još jednoga, Drugog svjetskog rata i na tlu Jugoslavije, kao što je to vidljivo u stihovima u naslovu ovog priloga:

Kud koje žure brzi kraci

a vode svi u bespuće $(. . .)^{55}$

Ipak se nikada ne smije previdjeti da je Vladan Desnica u ovim svojim godinama bio čovjek svjestan svoje kreativne literarne energije i da je vrlo mnogo pisao. Budući da malo znamo o sadržaju izgubljene knjige poezije, vrlo malo o izgubljenoj knjizi novela i, praktički, ništa o izgubljenoj knjizi eseja i kritika, osjećaj bespomoćnosti - ako je to primjeren izraz - očigledno nije bio i osjećaj apatije, dezorijentiranosti.

\section{„Povlačenje u NašE Kule OD BJElokosti“}

Unatoč tome što je Boško u to vrijeme predbacivao Urošu političku autoizolaciju u Kuli u Islamu Grčkom sve dok nije obolio, u previranjima u Jugoslaviji uoči izbora 1935. godine dijelio je njegovu suzdržanost prema daljnjem eksponiranju u Jugoslavenskoj narodnoj stranci. ${ }^{56}$ Poslije svega što se zbilo u odnosima između Uroša i vladike Irineja nakon vladi-

55 Vidjeti bilj. 18.

56 "Disputes results marred the May 1935 election. Open balloting gave the Jevtić list a revised 60.6 percent and Maček's Opposition Bloc, 37.4 percent. With support from Croatian Serbs and Bosnian Muslims, the Maček list won eight of every thirteen votes in Croatia and the western districts of Bosnia-Hercegovina. Although winning 303 of 
čina dolaska u Dalmaciju, nijedan od njih dvojice uoči najavljenih izbora nije osobno smio nastaviti s konfliktima jer to ne bi prošlo bez sankcija iz njihovih beogradskih središnjica. Mnogo je važnije što to Uroš, za razliku od vladike, više nije ni želio, sve slabije motiviran za bavljenje politikom u godinama nakon 1929. godine. Boško mu je pritom sekundirao:

La pace di Belgrado protumačena prema zadnjem ćaćinom pismu episkopu ima za nas dobru stranu da nam omogućava dostojanstven izlazak iz toga paštica i povlačenje u naše kule od bjelokosti. Sad će izborna borba zamijeniti dosadašnju - a tu nek vodi onaj koga se tiče. Mi, Desnice, imamo drugih briga, drugih dužnosti i drugih ideala. Zatvorićemo u sebe osjećaj poniženja i uvrijede i čekati mirno priliku za osvetu. ${ }^{57}$

Što su se izbori više približavali, Boško je sve više gubio smisao za proklamiranu obiteljsku spendid isolation. Bilo mu je teže u tom ustrajati jer je živio u Obrovcu, gdje se svakodnevno ponešto događalo, što ga je izravno tangiralo. Njemu su poseban problem bili ostrašćeni protivnici iz Privredno-kulturne matice za Sjevernu Dalmaciju, koji su radili sve ono što vladika nije smio učiniti. Barba Boško je Vladanu pisao o zbivanjima kao da Udružene opozicije u Obrovcu nije ni bilo. Budući da ovi izbori nisu lokalnohistorijski istraženi, otvoreno je pitanje što su sve radili, odnosno nisu radili Uroš i Boško Desnica, Sergije Urukalo, Lazar Matić, Pavle Zelić i drugi u Sjevernoj Dalmaciji.

Od ožujka do svibnja 1935. godine barba Boško se učestalije javljao Vladanu s neugodnim vijestima, ali i sve odlučniji da ipak ne bude pasivan u situacijama kada to u Obrovcu nikako ne bi ni smio sebi dopustiti. Između redaka njegovih pisama izbijalo je nezadovoljstvo što se i Uroš ne ponaša drugačije, primjerenije izazovima s protivničke strane, za koju „la pace di Belgrado“ (Beogradski mir) ništa nije značio. Boško je potpuno napustio imaginarne „kule od bjelokosti“ nakon što je stradao okoliš njegove karinske ladanjske kuće u izgradnji: „Juče na noć plemeniti Karinjani počupali su mi sve boriće i polomili stabla posađena oko mjesta na kom gradim kuću. Ne bi ćeo griješiti duše, ali bi se zakleo da je u

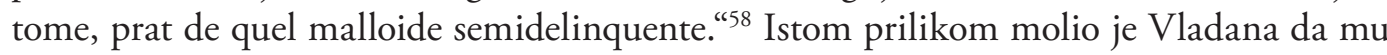
javi hoće li biti traga otvaranju njegova pisma kada ga primi u Splitu: „Molim te javi je li ti pismo stiglo u nepovrjegjenom stanju, jer se na našoj pošti otvaraju sva pisma koja sa bilo kojeg gledišta pobugjuju radoznalost izvjesne gospode. " ${ }^{\text {"59 }}$

Dva dana kasnije Boško se javio s novim pitanjima na koja je tražio hitne Uroševe odgovore. Vladan je pritom bio u statusu neke vrste kurira između njih dvojice jer je Uroš, izgleda, inače nerado pisao pisma:

370 seats in the new Skupština, Jevtić still sought to discredit the opposition. When his minions accused Maček of complicity in the king's assassination, that was too clumsy even for General Živković. He and four other ministers, including Finance Minister Stojadinović, resigned in June 1935.” John R. Lampe, Yugoslavia as History. Twice there was a country, Cambridge - New York, 1996., 174.

57 OOVD, kut. Prepiska do 1945. I., Boško Desnica - Vladanu Desnici, Obrovac, 1. ožujka 1935. „La pace di Belgrado“ očigledno je metafora za „odozgo“ iznuđeni sporazum između njih dvojice postignut u Beogradu uoči izbora 1935. godine. Njegovi su detalji zasad nepoznati. O konfliktima između Uroša Desnice i vladike Irineja Đorđevića u vezi s Privredno-kulturnom Maticom za Sjevernu Dalmaciju vidjeti: D. Roksandić, „Vladan Desnica i Magazin Sjeverne Dalmacije: književnik i (ne)moć tradicije“, 181-234.

58 OOVD, kut. Prepiska do 1945. I., Boško Desnica - Vladanu Desnici, Obrovac, 1. ožujka 1935. O tome je pisao još u jednom pismu: „Naš pitomi narod počupao mi u Karinu sve boriće koje sam zasadio oko kuće i polomio sva odrasla stabla, prenesena iz Grkovca uz veliki trud i trošak. Mislim da sam ti ovo već javio, ali sam toliko ojagjen i revoltiran da mi nije dosta." OOVD, kut. Prepiska do 1945. I., Boško Desnica - Vladanu Desnici, Obrovac, 12. ožujka 1935. Isto. 
Govori odma ćaći o ovom: pored sve tregna dei, pop Niko neprekidno rastura plavu knjigu i trapi je svakom ko hoće i ko neće ${ }^{60}$ Čujem da to isto radi i učitelj Lakić. Ja mislim da bi se mogli tužiti, jer ako je amnestirana krivica, počinjena štampanjem, ta amnestija ne može da djeluje neg pro preterito. Ako oni danas kolportiraju infamantni spis, ma koliko da je krivica štampanja tog spisa ugašena amnestijom, oni isto počinjaju kažnjivo djelo. Trebalo bi ih svakako udariti po prstima. Zamisli da to čini Lakić, kojemu smo ja i ćaća za 5 godina svakog mjeseca iz Zajednice slali po 100 D. a isto toliko Mile, a nesretni Mile Batinica 50. Ovog potonjeg uopće i ne pozdravljam. Govori svakako odma ćaći pa nek prouči stvar i nek me ovlasti. Ako on neće da tuži tužiću ja u svoje ime. Odgovori odma. ${ }^{61}$

Ovo je pismo istovremeno i zasad jedino svjedočanstvo da su Desnice tužile autore spominjane Plave knjige i uspjele dobiti djelomičnu zadovoljštinu. Naime, sudeći prema ovom izvoru, krivica autorâ bila je sudski sankcionirana, ali su oni nakon toga „amnestirani“. Njezino daljnje „kolportiranje“ - prema Boškovu mišljenju - moralo je stoga biti sudski gonjeno. Očito sumnjajući sve više može li se išta više očekivati od Uroša, Boško je najavio da će ovom prilikom sam podignuti tužbu. Dok se Uroš i dalje sve više povlačio iz aktivne politike, Barba je u kratkom vremenu, naprotiv, postajao politički sve involviraniji. Na rubu zapovjednog načina počeo je davati savjete Urošu što sve treba učiniti:

Treba svakako nastojati, a ja sam to učinio u formi formalnog zahtjeva, da u ovoj izbornoj kampanji Sergije izda letak u kom će tvrditi da je Matić upropastio Zadruge i prošundrao pola miljona zadružnog i državnog novca, a da je njegov zamjenik Zelić Falschspieler. Time će ih ubiti a u procesu ima osim svih onih dokaza iz brošire još i moje svjedočanstvo. Treba da mu to sugerirate i vi. Njegove šanse (tj. šanse Sergija Urukala - D. R.), uostalom, ne stoje tako očajno. ${ }^{62}$

Istih tih dana Boško je pisao svoje priloge za MSD 1935., što je za njega bilo veliko opterećenje pored svakodnevnih poslovnih i obiteljskih obaveza pa je i ovaj časopis instinktivno počeo doživljavati kao oruđe u sjevernodalmatinskim političkim obračunima. Zato je u pismima Vladanu toliko i kalkulirao što bi sve tko mogao reći ako bi se u MSD-u pojavio ovakav ili onakav prilog. Nema sačuvanog traga da je Vladan prihvaćao implikacije njegova rezoniranja. Međutim, primivši od Vladana esej o Mirku Koroliji, koji je kasnije i objavljen u $M S D-u$ 1935., Boško je reagirao euforično:

Primio sam i odma pročitao na dušak napis o Koroliji, pa ga još jednom pročitao pažljivo i korigirao neke sitnice. Stvar je vanredno dobra i uspjela. Prelazi po vrijednosti najbolje što je u tom žanru kod nas do sad dano. Za mene je iskreno i bez prećerivanja bolja od najboljih Skerlićevih eseja. Ti imaš nesumnjiv i neobičan dar za ove stvari i morao bi da intenzivnije radiš na ovoj vrsti. Ono što pišeš o nekoj navezanosti, zgruvanosti, nabačenosti to su sve pretjerana strahovanja brižljiva oca. U stvari toga nema. Ne mora ova vrsta radnja da bude kao školski primjer govora: esordio, dimostrazione, perorazione. Ovo su misli pametne i duboke, refleksije, zapažanja tačna i suptilna kakva je malo ko kadar da dade. Ja likujem i

60 Tregna dei ili Landfrieden: „Pax oder Frieden bedeutete den Schutz der Armen und ihrer Subsistenzmittel gegen die Gewalt des Krieges. Die Kriege wollte den Bauern und den Mönch vor den Folgen der Fehden schützen. Dies war die Bedeutung von treigna dei, Landfrieden. Er schützte spezifische Zeiten und Orte.“ Vidjeti: Ivan Illich, „Der gemeine Frieden“, Schlüsseltexte der Friedensforschung/Kea texts of peace studies/Textos claves de la Investigación para la Paz (ur. Wolfgang Dietrich i dr.), Münster - Wien 2006., 15-25.

61 OOVD, kut. Prepiska do 1945. I., Boško Desnica - Vladanu Desnici, Obrovac, 14. ožujka 1935.

62 OOVD, kut. Prepiska do 1945. I., Boško Desnica - Vladanu Desnici, Obrovac, 12. ožujka 1935. 
ja ti čestitam. Ovo je (...) porodice Desnica. Nek sad Matičari dadu svoj. ${ }^{63}$ Opet ti kažem da sam iskreno oduševljen. Da Mag[azin] ne donese neg ovo imao bi sa čim izaći. (...) Kad se već u Mag[azinu] ima ovakav adut onda prestaje potreba da donosiš stvari iz dnevnih listova pa ih svakako izostavi. Ako bude mršaviji neće za to biti manje dobar. ${ }^{64}$

Barbino „povlačenje u naše kule od bjelokosti“ iz pisma Vladanu od 1. ožujka 1935. završilo je potpunim obratom u pismu od 8. svibnja iste godine. Nije se bio ograničio samo na smišljanje predizbornih trikova, već je, prema vlastitom patetičnom priznanju, postao „vogj, haranger, tribun, rasturač zborova i lupež glasova“ među anemičnim pristalicama integralističke, a ništa manje i klijentelističke Jugoslavenske narodne stranke. Nakon ubojstva kralja Aleksandra I. ona se našla u neodrživom vakuumu. Očito potpuno iscrpljen nije imao snage za bilo što drugo osim za ispovijed Vladanu:

Izborna orgija, koja me je za 15 dana bila potpuno apsorbovala, dovršena je, porazom, ali dovršena! Go da un respiron, stresa sam prašinu sa sandala: povratio se alle tranquille apre di pace. Po našoj nesretnoj paladinskoj prirodi ja sam srnuo u bitku sa više elana neg iko a sa manje interesa neg iko. Svi su imali „in uno corde“ jedan šporki računčić Gjenero, Miljuši, Stole, Aljinović, ljekar, Mile, Sergije, Danilo, Petar, svi, osim mene. Vidio sam Sergja, deprimirana, obeshrabrena, dižorjentana, bez vjere u uspjeh, vidio sam sve ove druge sputane, neuputne, smetene, Milu zabrinuta za svoj položaj i sljedstveno nastojećeg da se ne eksponira i ne zamjeri protivniku, pa sam silom prilika postao vogj, haranger, tribun, rasturač zborova i lupež glasova. Nisam uspjeo i podlegao sam, ali kao Fransoa I kod Pavije. Imao sam zadovoljstvo da se tri puta sretnem sa Matićem i da vidim kako ne smije da me pogleda, da objeli zuba, kako crveni i kako se krije. Iz Karina, na koji se sve bilo okomilo i u kom bi bez mene bilo najviše 80 glasova, donio sam ih 317. Radio sam to da dokažem da Desnice nisu likvidirani i da još mogu da se isprse i da pokose. Sad je svršeno i ja se vraćam na normalu, sa osjećanjem emeritnog legionara. Žao mi je za Sergja jer je moralno ubijen a ekonomski upropašten. U samoj stvari bio on, bio Vuk ili ne bio niko, es kommt alles auf dasselbe hinaus! ${ }^{65}$

Osjećajući se na kraju istovremeno i kao francuski kralj Franjo I. kod Pavije i kao „emeritni legionar“, Boško se, dakle, nije osjećao poraženim kao drugi zato što predizborno nije imao „nijedan šporki računčić“, a doživio je zadovoljštinu da vidi kako ga netko kao Lazar Matić ne smije pogledati, što je za njega bio razlog za osjećaj trijumfa! Gušenje u besmislu provincijalizma bilo je za njega povratak „u normalu“. Izgleda da nije sačuvano nijedno Vladanovo pismo Bošku o izbornim temama, ali kako se Boško u svojim pismima nije ni referirao na njegove stavove, kao što je to obično radio, vjerojatno su bili krajnje suzdržani. Uroš je sigurno bio još suzdržaniji. Prema rukopisnoj „Bibliografiji Dr. U[roša] Desnice“, koju je sastavio Vladan, godine 1935. on je objavio tri članka, tj. dva in memoriam (kralju Aleksandru i Dušanu Baljku) te jubilarni „Jedna sedamdesetgodišnjica“, posvećen dr. Boži Peričiću. ${ }^{66} \mathrm{O}$ izborima ili bilo čemu drugom s eksplicitno političkim atribucijama nije objavio ni riječi.

U Osobnoj ostavštini Vladana Desnice za razdoblje od 1936. do 1941. godine praktički više nema sačuvanih Boškovih pisama s političkim sadržajima. Budući da ih je dovoljno ko-

\footnotetext{
63 Dvije Boškove rečenice u našem kurzivu kasnije su prekrižene! Izgleda da je to kasnije učinio Vladan jer je pritom upotrijebljena plava olovka koju je inače koristio.

64 OOVD, kut. Prepiska do 1945. I., Boško Desnica - Vladanu Desnici, Obrovac, 19. travnja 1935. U takvom euforičnom raspoloženju, ne zaboravljajući ni na trenutak predizborni rat s Maticom, upitao je istom prilikom Vladana: "Oće li ćaća dati što za ovog Mag[azina]? Trebalo bi svakako. Onda bi istup bio još impozantniji."

65 OOVD, kut. Prepiska do 1945. I., Boško Desnica - Vladanu Desnici, Obrovac, 8. svibnja 1935.
} 
ja svjedoče da su oni i dalje korespondirali, a naročito 1938. intenzivno i surađivali, moguće su različite pretpostavke, ali su sve one historiografski bespredmetne bez ozbiljnijih potvrda u vrelima. Obiteljska bliskost nije bila dovedena u pitanje, kao što svjedoči i citirano pismo od 13. travnja $1937 .{ }^{67}$ Daljnji je dokaz tome i jedno pismo iz 1938. godine:

Ovog su časa ćaća i majka otputovali poštanskim od 10 sati za Karin, gdje će ih, na vrh strane, dočekati Simo sa karocom. Stigli su u subotu u 3 pop[odne]. Dočekali smo ih ručkom, bili su juče sav dan i jutros otišli. Ćaća se dosta udebljao, ali inače mi nije učinio loš utisak. Ovo dana ovgje jeo je sa apetitom, ali se nije prejedao ni štravicjava. I uti morale nije mi učinio slab utisak: pamet je uvjek živa i budna, na mahove je i duhovit, odaje na časove malo škonforta, nanžec na sadašnjicu, nostalgije za prošlost i žali za mladost, ali nema onih strašnih paturnija, klonulosti i apižolamenata. Sve u svemu nije loše i ja sam ova dva dana bio u devetom nebu: vidio sam ga, narazgovara se s njim, evocirali prošlost, koja je i meni draga i vrlo sam zadovoljan. ${ }^{68}$

Bili su to inače vrlo neveseli dani za Boška. Što su mu djeca bila starija, financijske brige bile su veće, a nije imao prilika osjetnije poboljšati svoj položaj. U jednom kriznom trenutku odlučio je prodati svoju ladanjsku kuću za odmor u Karinu, jedva nakon što ju je konačno sredio. Istog dana kada je Vladanu pisao o susretu s Urošem i majkom, javio je da karinsku kuću prodaje, i to vladici Irineju! Nije se susreo s njime kada je došao da je pogleda, a kako se zbog toga osjećao svjedoči pismo:

Juče je episkop Irinej bio u Karinu da sopstvenolično pregleda kuću. Čujem da mu se dopala. Sad, kad je došlo do toga da se od nje rastajem, srce mi se cijepa i ne znam kako ću moći da se odvojim od nje. Nikad ljepšeg i zgodnijeg mjesta ni komodnijeg ljetovališta. Ono mi je bilo sve: sav luksus koji sam u životu dozvolio, sva moja zabava i razonoda. Ja sam izduravao i snosio ovaj pasji život u ovom paklenom i bogumrskom Obrovcu, samo snagom koju sam crpio iz iščekivanja ona 2 mjeseca karinskog odmora. Kad se sad promislim da toga više neće biti i da moj obrovački pakao neće imati više rašpirameni meni se smrkne. Ali svi sprcali: prodaj, prodaj ovake prilike nećeš imati nikad više i lako ću sad stegnuti srce i žrtvovati sebe još jedan put, sigurno ne posljednji. Ave Karin! ${ }^{69}$

Bošku je ostalo sanjati „kule od bjelokosti“ u Obrovcu. Uroš na njih nikada nije ni pomislio jer nije bio čovjek koji se zanosio iluzijama, iako se baš tih godina više bio posvetio Kuli u Islamu Grčkom nego ikada ranije. Vladanu su one mogle biti samo poticaj više u tadašnjim traganjima za „umjetničkim istinama“ na teme povijesti obitelji u Proljećima Ivana Galeba.

66 Prva dva teksta objavljena su u MSD-u 1935., a treći u splitskom Novom dobu od 14. prosinca t. g., s potpisom „Prijatelji“. Vidjeti: OOVD, kut. Uroš Desnica II.

67 OOVD, kut. Prepiska do 1945. I., Boško Desnica - Vladanu Desnici, 13. travnja 1937. Vidjeti bilj. 50. 


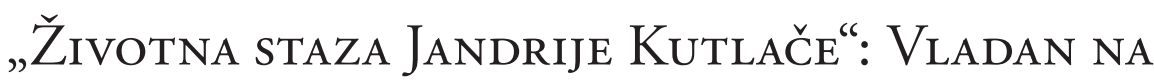 KRIVOM PUTU?}

Ujesen 1949., počinjući živjeti životom profesionalnog književnika, Vladan Desnica je prema svome suvremenom iskazu - podsjećamo - krenuo sa skromnim zavežljajem: „Od predratnih objavljenih stvari, nekog su spomena vrijedni esejčići o Dositeju i o Mirku Koroliji, novela-skica 'Životna staza Jandrije Kutlače' i nekoliko lirika, objavljeno sve to u Magazinu Sjev[erne] Dalmacije 1934, 1935, koji je i uređivao (... “. ${ }^{70}$ Njegov sadržaj nije navodio redoslijedom objavljivanja u $M S D$-u već logikom „spomena vrijedni“ pa se „novela-skica 'Životna staza Jandrije Kutlače'“ našla na trećem mjestu, a „nekoliko lirika“ na kraju, na četvrtom, iako je s „lirikama“ počeo umjetnički stvarati. Imajući na umu da je spomenuti životopis nastao u trenutku kada je Zimsko ljetovanje već bilo praktički pripremljeno za tisak, realno je pretpostaviti da je redoslijed navođenja mogao biti uvjetovan trenutačnim odnosom prema svom stvaralaštvu u mladim danima. „Životna staza Jandrije Kutlače ipak je ostala „novela-skica“. Iako Jandriju Kutlaču nije zaboravio, „novelu-skicu“ nije preradio u novelu, a nije ju iskoristio ni kao predložak za svoju preferiranu literarnu formu, roman, što mu je, izgleda, bila prvotna namjera. ${ }^{71}$

Vjerojatno nikada nećemo saznati zašto je tome bilo tako, ali možemo ustvrditi da ga je barba Boško, koji je, izgleda, prvi čitao prvu verziju novele-skice, istovremeno prvi, pa možda i najviše pokolebao. Najduže sačuvano Boškovo pismo u Vladanovoj osobnoj ostavštini odnosi se na „Životnu stazu Jandrije Kutlače“. Boško koji je upravo euforično hvalio njegove eseje o Dositeju Obradoviću i Mirku Koroliji te poneke pjesme, bio je sa svim obzirima krajnje suzdržan prema Jandriji Kutlači. ${ }^{72}$ Nakon nekoliko pohvala prešao je na kritike, kojih je bilo toliko da su iziskivale pretipkavanje cijelog teksta:

Dragi Vladane! Pročitao sam vrlo pažljivo i više puta novelu. Zamisao je vrlo srećna. Tip živ i istinit. Psihologija tačna. Ima momenata vrlo jakih i od efekta n. pr. revolt sina i ona dva skidanja rozete. Samo mi se čini da je obrada nejednaka, pomalo uglasta i mjestimice pada u banalnost. Ja sam, koliko sam za to sposoban, revidirao i pokušao da zaoblim. Naročito sam je malo šfronda ${ }^{73}$ per darghe più aria, più slancio. $\mathrm{Ti}$, razumije se, moje opaske i korekture uvaži ili ne uvaži prema svom ukusu. Neke sam zabilježio u ovom folio di lunci, a neke u samom tekstu, jer će se i onako morati prepisivati. ${ }^{74}$

Boško je bio svjestan da Vladan neće htjeti odustati od objavljivanja novele u $M S D$-u 1935., a sam je bio uvjeren da to neće biti dobro za njegovu književnu reputaciju pa mu je dosta nesmotreno - kao što je u kriznim situacijama inače znao reagirati - predložio da je objavi pod pseudonimom, koristeći se imenom njihova nedavno preminulog zadarskoga kućnog prijatelja Josipa Berse (1862. - 1932.):

70 OOVD, kut. Izdavački ugovori, „D E S N I C A V la d a n, Urošev“.

71 D. Marinković, „Biografija Vladana Desnice“, 230.

72 Ovo pismo Boška Desnice Vladanu Desnici nije datirano, ali je Vladan kasnije u zaglavlju prve stranice upisao godinu „1934“. Čini nam se da je to bilo kasnije, početkom 1935., jer je reakcija Vladana Desnice uslijedila prije 1. ožujka 1935., kada mu se stric ponovo javlja o istoj temi.

73 Sfrondare: „tr. (po)kidati lišće (s ogranka); fig. odstraniti nepotrebno, ukloniti suvišno“. Mirko Deanović - Josip JERneJ, Talijansko-hrvatski rječnik, Zagreb 2002., 908.

74 OOVD, kut. Prepiska do 1945., I., Boško Desnica - Vladanu Desnici, Obrovac, [prije] 1. ožujka 1935. 
U pogledu štampanja ja imam jednu ideju; štampaj je u Magazinu ali ne pod svojim imenom, već učinimo jedan mali trik, jednu mistifikaciju: podmetnimo je, diskretno, pokojnom Bepu Bersi. To ima svoje dobre strane: ako je potpišeš ti onda će svi primiti novelu sa nepovjerenjem i skepsom koju svi instinktivno imaju prema početničkim tekstovima. Ako je podmetnemo Bersi, svijet će je primiti sa strahopočitanjem i pijetetom. ${ }^{75}$

Toliko se bio uživio u svoju dosjetku da je u glavi razradio detalje, napisao priču u priči i servirao je Vladanu, završivši formulacijom koja je odavala poslovnog, poduzetničkog Desnicu: „Varaj je ovako - pa se ne staraj, jer vjeruj da l'etichetta fà il bon vin! ${ }^{\text {“"6 }}$ Napisao mu je:

Stvar treba izvesti lukavo: potpis: tre stelle a pod naslovom, u kurzivu napomena redakcije: Od lica vrlo bliska jednom našem nedavno preminulom, ali već davno zaboravljenom, starijem književniku primili smo ovu novelu, nagjenu u njegovoj književnoj zaostavštini, uz molbu da je objavimo. Lice koje nam je šalje ne želi da ovom publikacijom ništa da doda već staloženoj književnoj reputaciji čovjeka, čijem se kultu ono posvetilo pa nas moli da ne iznosimo auktorova imena. Tu želju primamo kao zakon a novelu donosimo sa toliko velikim zadovoljstvom u koliko nam ona dokazuje, da je njezin auktor i ako je živio odvojen od svog naroda iz prikrajka pratio i bilježio njegove zgode i u duši svojoj sačuvao netaknute sve one prisne, idealne misli koje ravnaju nacionalnim bilom i determinišu pripadnost. Objavljujući ovo njegovo posmrče, mi vršimo i čin dužnog pijeteta prema jednoj markantnoj figuri dalmatinskog intelektualca iz generacije, koja je danas na izdisaju. ${ }^{77}$

Vladana uopće nije dirnula stričeva želja da ga zaštiti od nepoželjnih kritika. To se može zaključiti iz Boškova obrambeno intoniranog pisma od 1. ožujka 1935. Vjerojatno su ga čak povrijedili, ali se ni stric, uzmaknuvši, nije predavao. Predložio mu je da za MSD 1935. umjesto jedne napiše dvije novele:

Drago mi je da ćeš štampati novelu pod svojim imenom. Ja sam ti savjetovao onaj trik da ti prištedim gorčinu, koju će ti nanijeti oni, koji budu pisali o njoj ne obzirom na njezinu vrijednost ili nevrijednost, već obzirom na ličnost pisca: „početnički rad“ „nosi sva obilježja prvih plodova i t.d.“ „Želimo mladom piscu i t.d.“ Sve stvari koje nerviraju a koje bi se izbjegle jednom zgodnom mistifikacijom. Još bi bolje bilo kad imaš 2 novele jednu štampati pod imenom a drugu podmetnuti, pa kad se istrču onda otkriti karte. ${ }^{78}$

Ne raspolažemo prvom verzijom „Životne staze Jandrije Kutlače“ pa je zasad nemoguće reći što je Vladan uistinu bio napisao i kako je sve i na kojim mjestima tekst trebao biti promijenjen pa i preoblikovan. Životno mnogo iskusniji stric očito se bio uplašio što bi se sve moglo prigovoriti Vladanu nakon objavljivanja novele, a što bi moglo dovesti u pitanje književni status koji je u njegovim očima već bio stekao svojim esejima i pjesmama i - što je Bošku bilo mnogo važnije - koji bi tek mogao steći. Znajući, s druge strane, koliko se Vladan inače identificirao sa svime što radi, unio se u minuciozno kritičko čitanje rukopisa i kao književnog djela i kao svjedočanstva o Kutlačinu vremenu. Htio mu je pomoći najviše što je mogao da novela u konačnici bude što bolja, tim više što je bila riječ o „Sjevernoj Dalmaciji“, njezinu naslijeđu i njihovu odnosu prema tom naslijeđu. Jedna od prvih među mnogobrojnim sugestijama odnosila se na korištenje pojmom "Zagora" u priči o Jandriji Kutlači, čovjeku iz dalmatinske Bukovice:

78 OOVD, kut. Prepiska do 1945., I., Boško Desnica - Vladanu Desnici, Obrovac, 1. ožujka 1935. 
Zagora je riječ vrlo omiljena u Splitu, gdje znači sve što nije na moru, što je „u Vlaje“. Kod nas je nepoznata. Meni je lično mrska, jer mi izaziva predstavu nesvarljivog Šimunovića. Mislim da je i geogr[afija] netačna, pošto je to lokalni naziv za područje Lećevica - Muć. Ragje bi ostao kod Bukovice. ${ }^{79}$

„Spalatinizirani“ Vladan bio je prihvatio pojam „Zagora“ kao sinonim za kontinentalnu Dalmaciju. Bošku je to bilo neprihvatljivo jer je itekako znao da ne postoji jedna kontinentalna Dalmacija, nego mnoštvo njih vrlo različitih od Kninske do Neretljanske krajine i bilo mu je nepojmljivo da bi Kutlača mogao potjecati iz bilo koje druge osim iz Bukovice. Na sličan način, „spalatinizirani“ Vladan tada je suviše malo znao i o zavičajnom Zadru da mu u noveli ne bi promakli previdi koji su uzbuđivali Boška:

Alviz je njemački Luigi. Ako hoćeš da tako ostane onda ga pretvori u Luigji, jer je nevjerovatno da zadarski kanonik pledira za njemačku verziju svetačkog imena. Ali ako je Jandrija ćeo da imenom sina (kao Kovačević) posvjedoči i dokaže svoje osjećaje prema Domu onda moraš da ga prekrstiš jer Alojz nije habsburško ime. Onda treba da se zove Leopoldo, Federico, Maksimilijan, Otto i t.d. ${ }^{80}$

Vladan, dakako, nije imao nikakvo izravno iskustvo službe u c. i k. vojsci pa mu nije preostalo ništa nego potruditi se naučiti mnoštvo detalja bez kojih se ne bi ni smio upustiti u pisanje novele o „langerdineru“ Jandriji Kutlači:

(...) kao ornista on je morao znati pisati od ranije. Uopće nepismeni nisu mogli da postanu šarže u austr[ijskoj] vojsci, a poglavito oni koji bi ostali da dalje služe kao „langerdineri“ “ ${ }^{81}$

Ili:

(...) naviksane su samo cipele. Bolje osvjetlanoj jer to obuhvata i botune i lakne dijelove. ${ }^{82}$

Ili:

karijere tada nije još bilo, bolje uspjeh u životu ${ }^{83}$

Lista primjedaba na „Životnu stazu Jandrije Kutlače“ neobično je dugačka. Navedeno Boškovo pismo dijelom je vrlo teško čitljivo, a rekonstrukcija je u ponečem nemoguća bez Vladanova nedostupnog izvornika. Stoga je samo djelomično moguće provjeriti što je sve Vladan izmijenio u verziji objavljenoj u MSD-u 1935. Kratkoročno, Boško nije postigao svoj cilj. Dugoročno je uspio utjecati na Vladana da počne drugačije razmišljati o ovome svom književnom ,junaku“, ali zato što je njemu samom do toga bilo stalo.

Vjerojatno nikada nećemo moći odgovoriti na pitanje kakav je i koliki bio izravan stričev utjecaj na Vladana kada se odlučivao odustati od pisanja romana o Jandriji Kutlači. Sudeći prema više njegovih kasnijih izjava načelne naravi, moguće je pretpostaviti da je shvatio da je izabrao lik koji ga je književno unaprijed suviše limitirao i, drugo, da je krenuo putem

\footnotetext{
79 OOVD, kut. Prepiska do 1945., I., Boško Desnica - Vladanu Desnici, Obrovac, [?] 1934. Pismo izvorno nije datirano. Godinu je naknadno upisao Vladan Desnica.

80 Isto.

81 Isto.

82 Isto.

83 Isto.
} 
koji je implicirao takvu razinu konkretnohistorijske kontekstualizacije da ne bi mogao ni napisati roman po mjeri vlastitih kriterija. Budući da je 1936. godine počeo pisati Proljeća Ivana Galeba, „Životna staza Jandrije Kutlače“ ostala je tek „,novela-skica“, kao što je on sam zapisao 1949. godine.

\section{Protiv „AHISTORIJSKOG PASATIZMA“}

Raspravljajući o koncepciji MSD-a 1935., Vladan Desnica je s Boškom a vjerojatno is Urošem dogovarao kako historizirati moderni koncept Sjeverne Dalmacije. Iako su neki prilozi na povijesne, kulturološke i etnografske teme objavljeni u $M S D$-u 1934. pridonosili razumijevanju tog koncepta, bili su suviše fragmentarni da bi javnosti mogli osigurati pouzdaniji uvid u uredničkoj optici dijakronijski projicirani kvazitotalitet subregionalne problematike od 17. do 20. stoljeća, bitan za razumijevanje modernog koncepta Sjeverne Dalmacije.

Praktički je to značilo, pored svega ostalog, krenuti od hipotetičkog, imaginarnog početka te kritički rekonstruirati značenje pojma Contado e Territorio di Zara, tj. knežije i teritorija Zadra, koji je nastao nakon velikih promjena granica u mletačko-osmanskom Kandijskom ratu (1645. - 1669.) u Dalmaciji i na Mediteranu. Mletačka državna i zadarska gradska vlast tada se bila protegla s područja svoje „stare stečevine“ (acquisto vecchio) na područje „nove stečevine“ (acquisto nuovo), s područja kontada ili knežije na područje teritorija, s litoralnog i inzularnog „bodulskog“ područja na kontinentalno „morlačko“ područje Ravnih kotara i Bukovice. Kako je iz istog vremena potjecao predak Desnica serdar Stojan Janković (cca. 1636. - 1687.) - jedan od rijetkih „Morlaka“ koji su ostavili dubokog traga i u službenim vrelima i u pučkoj oralnoj tradiciji - poklopili su se urednički interesi za historiziranjem spomenutog koncepta s interesom za historiografsko kontekstualiziranje roda Mitrovića Jankovića, njega samog te njegova roda conte Jankovića u povijesti knežije i teritorija Zadra 17. i 18. stoljeća. $^{84}$

Boško, dobar poznavalac zadarskih arhiva, pouzdano je znao da je rukopis Šimuna Ljubavca Storica Disertazione del Contado e Territorio di Zara del Dottor Simon Gliubavaz dedicato a S. E. Leonardo Foscolo, Provveditore Generale di Dalmazia et Albania (Povijesna disertacija o zadarskoj knežiji i teritoriju doktora Šime Ljubavca posvećena Leonardu Foscolu, Generalnom providuru Dalmacije i Albanije) nastao po providurskoj narudžbi u razdoblju nakon širenja mletačke vlasti na „novu stečevinu“ sredinom 17. stoljeća te da je svojevrsni ključ za pristup rekonstrukciji koncepta i njegove teritorijalizacije. ${ }^{85}$

84 Osim Istorije kotarskih uskoka vidjeti i: Boško Desnica, Stojan Janković i uskočka Dalmacija: izabrani radovi (prir. Srđan Volarević), Beograd 1991. (ćir.); Isti, Sabrana djela (prir. Milorad Savić), Zagreb 2008. (ćir.).

85 „Ljubavac, Šimun (Simeone Gliubavaz), hrvatski povjesničar (Zadar, VII. 1608 - Zadar, 20. I. 1663). Odvjetak zadarske patricijske obitelji. Studirao u Padovi (1631-37), gdje je doktorirao pravo, a poslije je u Zadru obavljao nastavničku i sudačku službu. Kao pripadnik kruga istaknutih Zadrana, okupljenih oko V. Pontea, često se dopisivao s I. Lučićem. Jedno pismo iz njihove korespondencije, u kojem je Ljubavac iznio svoja razmatranja o hrvatskom kralju Stjepanu II. i vojnom pohodu Ladislava I. Arpadovića iz 1091., čuva se u British Museumu. Glavno mu je djelo geografsko-povijesni prikaz zadarskoga područja, Opisivač zadarskog distrikta. Povijesni zapisi (Agri jadrensis illustrator. Memorie istoriche), sačuvan u pet rukopisnih primjeraka i dijelom objavljen u zadarskome časopisu La Domenica 


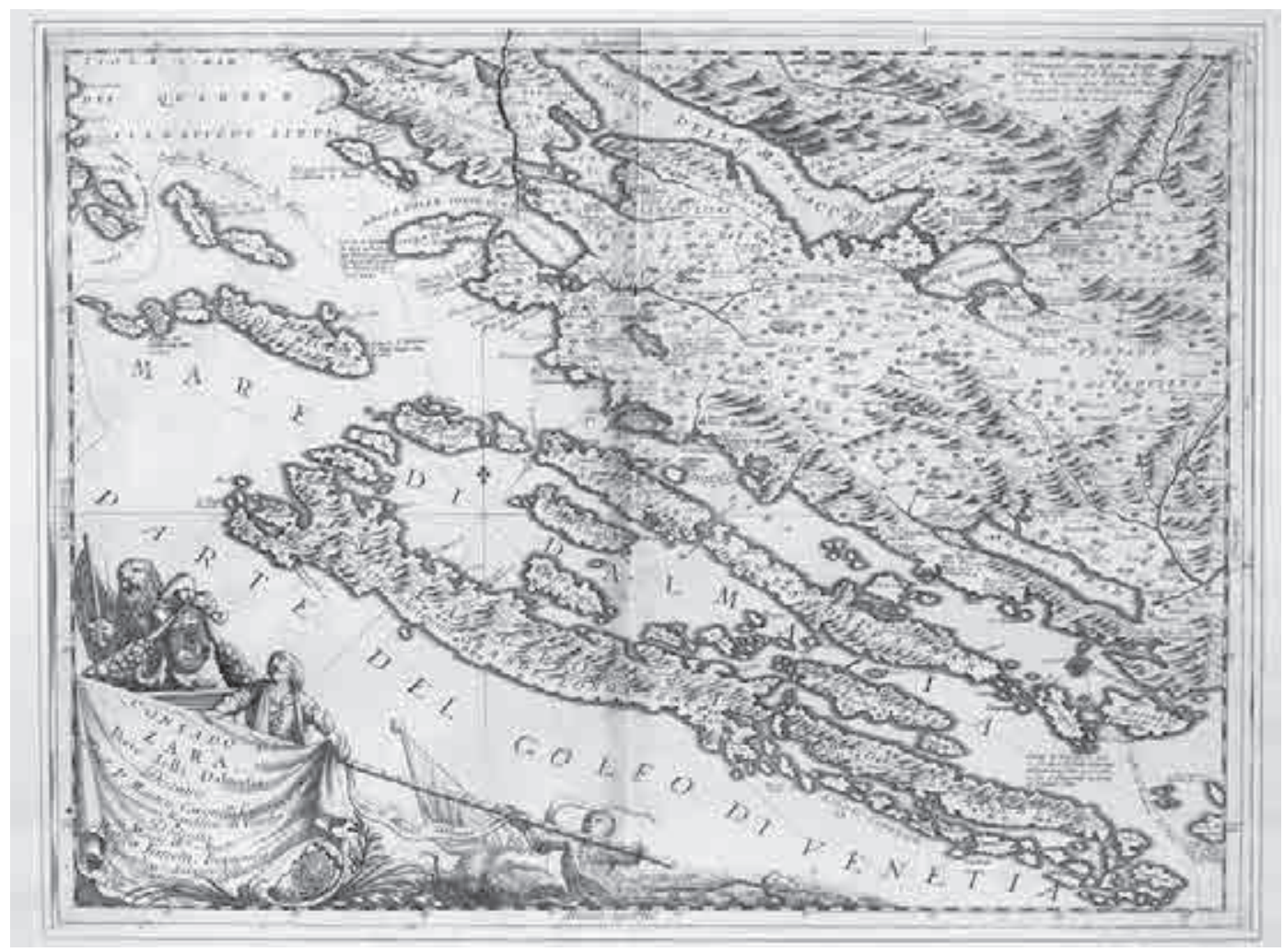

Sl. 5. Coronellijeva karta „Contado di Zara“ (1688.)

Znao je također da su drugi ključ karte mletačkog kartografa Vicenza Marije Coronellija (1650. - 1718.), inače jednoga od najboljih u dugoj tradiciji mletačke kartografije ranoga novog vijeka. Podosta je znao i o drugim ranonovovjekovnim slikovnim izvorima. Izdvajamo Boška, nimalo ne podcjenjujući Uroša i Vladana jer su svi oni in patrimonio naslijedili bogatu i raznovrsnu kulturnu baštinu, pohranjenu ponajviše u Kuli Stojana Jankovića u Islamu Grčkom, a manjim dijelom i na obrovačkom posjedu. Sva su trojica s razumljivim generacijskim razlikama produbljivala svoja znanja o zavičajnim i rodnim tradicijama, ali je Boško tome bio posvećen s najviše strasti i akribije. Magazin Sjeverne Dalmacije bio je prilika da se toj tradiciji dade novi smisao u sjevernodalmatinskoj suvremenosti.

Vladanov je utjecaj na Boška ipak imao svoje granice jer ovaj nije htio pisati za MSD o Stojanu Jankoviću na način koji bi implicirao sintetičke ocjene, nužne za zamišljenu konceptualizaciju. O njemu je ionako već bio objavio više radova pa se nikako nije htio ponavljati na razini onoga što je već znao i obznanio. Nakon što je MSD 1935. izašao, još jedanput je Vladanu obrazložio svoje odbijanje:

(1890-91). God. 1652., na zahtjev mletačkih vlasti, napisao je raspravu Povlastice Dalmacije (Prerogative di Dalmazia), kojom je nastojao dokazati pravo Mletačke Republike na naziv kraljevstva s obzirom na to da je u svojoj državi posjedovala 'regnum' Dalmaciju. Prikupio je zbirku rimskih natpisa, koju je poslije upotrijebio I. Lučić, a pripisuje mu se djelo $O$ smještaju Ilirika (De situ Illyrici). Među važnijim su njegovim sačuvanim rukopisima Povijesni zapisi o Zadru (Memorie di Zara), popisi zadarskih biskupa i nadbiskupa te zbirka starih natpisa iz Zadra i okolice." Vidjeti: „Ljubavac, Šimun“, Hrvatska enciklopedija (http://www.enciklopedija.hr/natuknica.aspx?id=37739). 
Stojana neću moći napisati dok ne odem lično u Mletke a to znači nikada. Po materijalu koji imam ispao bi samo jedan torzo, vrlo krnj i nereljefan: ili ću dati nešto što doista vrijedi, nešto živo, plastično, istinito ili nek se stara potomstvo t.j. ti, ili Braco ili Uroš II. ${ }^{86}$

\section{Ustvari, Boško je više nego Vladan zazirao od predvidljivih prigovora koji su mogli} potjecati od ljudi koji su obitelji iz raznih razloga bili neskloni ili, pak, njezini otvoreni neprijatelji s optužbom da su MSD pretvorili u Familienmagazin. Vladan je kao urednik drugačije razmišljao jer je bio uvjeren da slijedi uređivačku logiku koja u osnovi legitimira sve što je u časopisu radio. Stoga se nije puno obazirao na ovakve stričeve „svakidašnje jadikovke“, ali je u konačnici prihvaćao njegove odluke, kao što je od Boška očekivao da će on prihvaćati njegove. ${ }^{87}$

Prestankom izlaženja $M S D$-a ostao im je zajednički interes prezentirati spomenuti Ljubavčev rukopis, koji se u različitim varijantama nalazio pohranjen u Zadru i Veneciji. ${ }^{88}$ Pritom su im ambicije varirale u širokom rasponu. Desnice nisu odlazile u Zadar nakon 1920., ali su ostale u komunikaciji s ponekim obiteljima i pojedincima. Boško je zbog svojih historiografskih i kulturoloških studija - uvelike ovisnima o zadarskim arhivima i knjižnici Paravija - održavao više veza nego ostali, ali su sve one bile sporadične. Dakle, ništa u ovom slučaju nije bilo jednostavno dogovoriti. Čekanje naručenog prijepisa Ljubavčeva rukopisa jako se odužilo i trajalo je mjesecima. Barbine poruke Vladanu s time u vezi slijedile su jedna drugu: „Ljubavca još nisam dobio, (...) Ljubovcu ću napisati malo uvoda i obilato

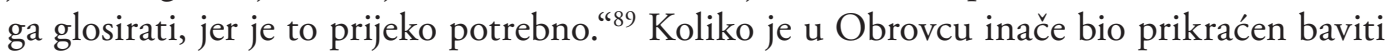

86 OOVD, kut. Prepiska do 1945., I., Boško Desnica - Vladanu Desnici, Karin, 16. srpnja 1935. Braco je bio Boškov sin Stojan, a Uroš II. Vladanov sin, rođen 1944., koji je doista dobio ime Uroš. Nijedan od njih dvojice nije se posvetio ovoj Boškovoj želji, a monografija o Stojanu Jankoviću još uvijek nije napisana. Što se vrela tiče, Barba nije bio pravedan prema samom sebi jer je njegova voluminozna zbirka zadarskih dokumenata, posmrtno objavljena Istorija kotarskih uskoka, bila prepuna izvornih obavijesti o Stojanu Jankoviću, a i razni njegovi prilozi s njime u vezi nastali su kritičkim korištenjem povijesnim vrelima.

87 U odnosima među Desnicama u ovo doba ponekad je vrlo teško razlučivati granice između tradicionalnih i modernih obrazaca ponašanja. Sva su trojica pojedinačno bila oštro personalizirana, ali ih je nemoguće razumijevati ignorirajući njihove tradicijske obiteljske autopercepcije.

88 Boško i Vladan najozbiljnije su shvatili ovaj zadatak, a to ih je najprije obvezivalo identificirati korištenjem raspoložive literature i vlastitim istraživanjima koliko prijepisa ovog rukopisa uopće ima, koji je među njima izvornik, koji je na temelju kojeg nastajao itd. O tome je kasnije izvijestio u svom članku o Ljubavcu 1938. godine: „Agri iadrensis illustrator odnosi se na najglavnije Ljubavčevo djelo, opis zadarskog kotara, koje nam se sačuvalo u pet rukopisnih primjeraka: dva u zadarskoj gradskoj biblioteci Paravia, jedan u biblioteci zadarske gimnazije, jedan u muzeju Correr u Mlecima a jedan kod nasljednika pok. Savjetnika Alačevića. Primjerak gimnazijske biblioteke ima na kraju napomenu, da je taj primjerak u maju 1800. g. prepisao Mate Pulić sa primjerka kneza Frana Borelli. Obzirom na rodbinske veze porodice Borelli sa Alačevićima, vjerovatno je da je Borellijev primjerak onaj koji se sada nalazi kod Alačevića. Jedan od primjeraka Paravije i onaj muzeja Correr nose, sa malim međusobnim razlikama, naslov Memorie istoriche del Dottor Simon Gliubavaz, nobile Zaratino, all. Ill.mo et Ecc.mo Signor Provveditor Generale di Dalmazia et Albania Leonardo Foscolo. Pod ovim je potonjim naslovom to djelo objavio zadarski sedmični list 'La Domenica' u godinama 1890 - 1891, posluživši se, mislimo, Alačevićevim primjerkom. Drži se da je primjerak muzeja Correr Ljubavčev original, što je lako moguće s obzirom na okolnost da je Ljubavac napisao to djelo po Foscolovom nalogu i Foscolu ga posvetio, pa je taj original nesumnjivo dospio sa Foscolom u Veneciju i lakše mogao da svrši u mletački muzej, nego prepisi koji su ostali u Zadru. Uostalom, među raznim primjercima nema bitnih razlika. Ja sam dao sravniti prepis učinjen sa jednog od Paravijinih primjeraka sa originalom Correrove zbirke i ustanovio vrlo malo varijanata, ali, što je značajno, većinom na štetu originala.“ Vidjeti: Boško Desnica, „Zadranin Šimun Ljubavac. Jedan dalmatinski erudit XVII vijeka“, Glasnik Primorske banovine, god. 1/1938., br. 1, 173-181; citat sa str. 176.

89 OOVD, kut. Prepiska do 1945., I., Boško Desnica - Vladanu Desnici, Obrovac, 1. ožujka 1935. Kako se u to doba teško dolazilo do stručnih izdanja, međusobne posudbe bile su jedan od ustaljenih načina komunikacije među ljudima od pera. Koji su Spomenici ovdje u pitanju teško je reći pa nema smisla praviti pretpostavke. Poruka je vrlo važna za temu ovog članka jer svjedoči da je Boško u osnovi imao namjeru pripremiti izdanje koje će biti manje usredotočeno na Ljubavca samog, a više na tekst kao izvor za povijest Sjeverne Dalmacije. 


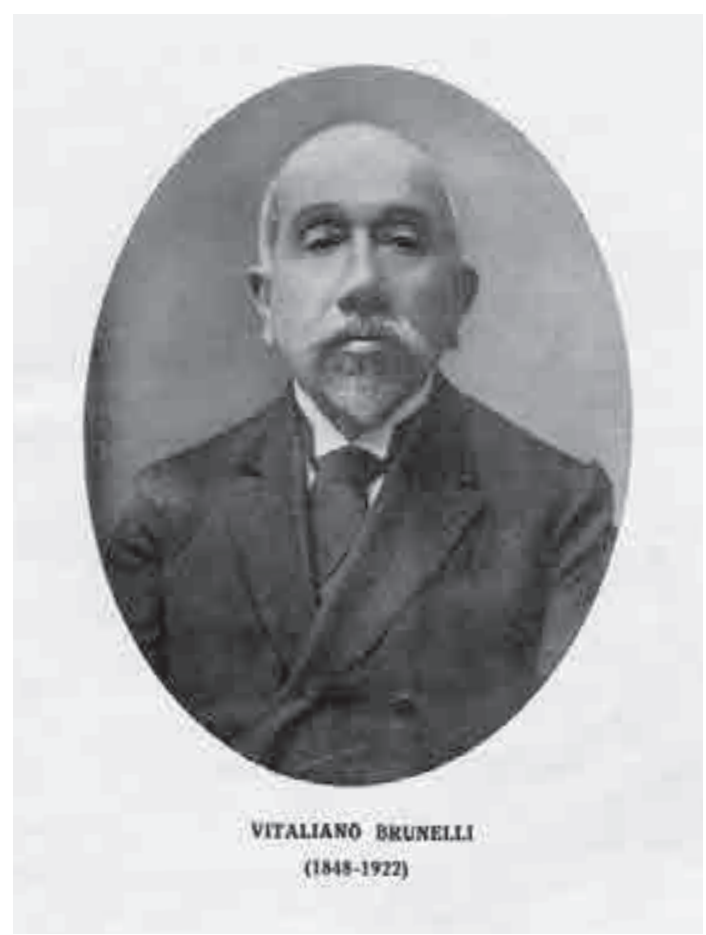

Sl. 6. Vitaliano Brunelli - nezaobilazan u pristupu opusu Šimuna Ljubavca se ovom temom najbolje se vidi iz sljedeće rečenice $\mathrm{u}$ istom pismu: „Nagji mi svakako (u Abramića) i pošalji Ljubićev Dizionario degli uomini illustri ili, ako ne htjedne da ti ga dade, bar prepiši ono što donosi ad vocem Ljubavac." 90 Vladan mu je hitro izašao u susret, ali time nije bio od neke koristi: „Ljubovca ću glosirati i napisati kratak uvod po Brunelu, jer ovo Ljubićevo nije ništa. Uostalom prijepis mi još nije stigao." ${ }^{91}$ Ako je i mogao izdvojiti ponešto vremena za Ljubavca, nije se mogao koristiti njime kako je htio jer mu iz Zadra prijepis i dalje nije pristizao: „Čim stignem prihvatiću se posla da ti sredim ono nekoliko stvarčica za garnirung, a urediću i Ljubavca koji, fra parentesi, još nije prispio. " 92

Istovremeno su se obojica bila posvetila traganju za Coronellijevim kartama, suvremenim vinjetama, Ljubavčevim portretom itd.: „Ne znam je li knjiga čiji mi naslov šalješ poznati Coronellov atlas Istre, Dalmacije i Levanta. ${ }^{93}$ Ako jest tad ga ja dobro poznam. Ali u atlasu koji ja poznam nije bilo vinjete Obrovca. Ona vinjeta koju imate i vi potječe iz nekog francuskog atlasa. Treba svakako da ili fotografišeš ili dadeš precrtati vinjete svih mjesta iz našeg kraja, to učini neizostavno

90 OOVD, kut. Prepiska do 1945., I., Boško Desnica - Vladanu Desnici, Obrovac, 1. ožujka 1935. Mihovil Abramić (1884. - 1962.), ravnatelj Arheološkog muzeja u Splitu od 1926. do 1950.

91 OOVD, kut. Prepiska do 1945., I., Boško Desnica - Vladanu Desnici, Obrovac, 12. ožujka 1935. Šime Ljubić je malo što pouzdanije znao o Šimunu Ljubavcu: „GLIUBAVAZ Simeone di Zara lasciò molte preziose carte tendenti ad illustrare la sua patria e l'ampio territorio ch'ella in alora possedeva. Restaci di lui un manoscritto inedito, che illustra tutte le iscrizioni Zaratine, ch'erano state dissotterrate sino metàdel secolo XVII., un'altro citato dal Fortis: de situ Illyrici." Simeone GLIUBICH, Dizionario biografico degli uomini illustri della Dalmazia, Vienna - Zara $1856 ., 160$. Zadarski povjesničar Vitaliano Brunelli (1848. - 1922.) objavio je u zadarskoj Rivista Dalmatica opsežnu studiju „Giovanni Lucio“, koja sadržava mnoštvo obavijesti o Šimunu Ljubavcu i njegovoj suradnji. To je bilo prvi put nakon spomenutog objavljivanja Ljubavčeva rukopisa u La Domenica da se Ljubavcu istraživački posvećuje veća pažnja i pokušava interpretirati važnost njegovih doprinosa u dugogodišnjoj suradnji s Ivanom Lučićem. Vidjeti: Rivista Dalmatica, anno I., fasc. 1º, Zara 1899, 5-24; anno I., fasc. 2º, Zara 1899, 119-139; anno I., fasc. 40, Zara 1899, 24-51; anno II., fasc. 1ª, Zara 1900, 32-52 i anno II., fasc. 4º, Zara 1901, 17-21. Recentne studije o Lučiću redovito referiraju i na Ljubavca. Vidjeti: Miroslav Kurelac, Ivan Lučić. Otac hrvatske historiografije, Zagreb 1994. Prema autorovu popisu korištene literature, izgleda da je Boško Desnica još uvijek jedini koji je Ljubavcu posvetio poseban prilog. M. Kurelac ga je registrirao, ali ga nigdje u monografiji nije citirao.

92 OOVD, kut. Prepiska do 1945., I., Boško Desnica - Vladanu Desnici, Obrovac, 21. ožujka 1935.

93 Riječ je o atlasu Vincenza Coronellija (1650. - 1718.) Atlante Veneto: Isolario descrittione geografico-historia, objavljenom u dva toma u Veneciji 1691. - 1697. (http://www.europeana.eu/portal/hr/record/92004/BibliographicResource_2000059213894.html). Njegova zadarska karta iz 1688. godine naslovljena je: „Contado Di Zara. Parte della Dalmatia Descritto... 1688.“ (https:/www.raremaps.com/gallery/archivedetail/0211/Contado_Di_Zara_Parte_della_Dalmatia_Descritto\%E2\%80\%A6_1688/Coronelli.html) 
i odma. Obrati se na brata Dra Gjurkovića. Ljubavčeve slike, nažalost, nema nigje. Od sve one plejade pisaca ima slika samo Valerija da Ponte u Paraviji. Rukopis još ne stiže. " ${ }^{\text {"94 }}$

Do konca mjeseca iščekivanje prijepisa rukopisa bilo je doseglo vrhunac: „(...) ali se Ljubavac još ne pomalja. Do sad sam urgirao 10 puta. (...) Javi mi o vinjeti Obrovca u Coronella. Jesi li je vidio? Ako postoji, svakako je daj snimiti. "95 Barba je postajao sve nestrpljiviji: „Ljubavca nema. Obećan mi je za četvrtak neizostavno. Vidi svakako vinjetu kod

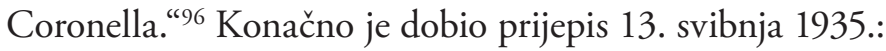

Jučer sam primio Ljubavca: 97 stranica otkucanih, ali ne velikih. Ima mnogo neispunjenih mjesta, naročito kod naznačivanja broja sposobnih za oružje u pojedinim mjestima. Vidi svakako je li to u onom izdanju u Domeniki popunjeno ili su i tu ta mjesta označena tačkama. ${ }^{97}$ Prepisivanje je stajalo dosta skupo. Večeras počinjem sa identifikacijom na specjalkarti i sa anotiranjem rukopisa. Trebaće dotjerati i ortografiju. Čim svršim poslaću a mogao bi slati i na vale de man in man. ${ }^{98}$

Stric Boško se očigledno namjeravao upustiti u veliki posao. Kako se Vladan žurio što prije objaviti $M S D$ 1935., nije mogao čekati da on završi tako zahtjevan rad pa je u ovom slučaju sam morao odustati od inicijalnih zajedničkih namjera. Bila je to za njega teška odluka. Pogodila ga je kao i Boška, ali je Boško bio taj koji je osjećao potrebu opravdati se nakon izlaska sveska iz tiska u srpnju 1935.: „Ljubavca je bilo nemoguće prirediti za štampu, jer to traži najmanje 4 mjeseca rada i saradnju ljudi sa terena, od kojih ti $99 \%$ uopće ne odgovara na zamolnice (fra i altri i pop Mirko!)." ${ }^{\text {(99 }}$

Međutim, zajednički su širili daljnje granice započetog posla. Tome je najbolji dokaz napor koji su uložili pokušavajući doći do najstarijih slikovnih prikaza običnih ljudi u Sjevernoj Dalmaciji. Dali su se u potragu i za serijom bakroreza augsburškog barkoresca i nakladnika Martina Engelbrechta (1684. - 1756.) - pogrešno ga imenujući „Engelbert“ koja je, prema obavijestima kojima su raspolagali, sadržavala i prikaze Morlaka. Stotinu i pedeset koloriranih bakroreza iz Engelbrechtove serije Théâtre de la milice étrangère; Schaubühne verschiedener in Teutschland bishero unbekannt gewester Soldaten von ausländischen Nationen (Augsburg 1742. - 1745.) dugoročno je sigurno imalo velik utjecaj na stvaranje egzotičnih stereotipa o „divljima“ s europskog Jugoistoka. Ipak su oni bili i ostali prvorazredni povijesni izvor jer su nastali u vrijeme kada, pored krajišnika, i Trenkovi panduri žare i pale po Njemačkoj u vrijeme Rata za austrijsku baštinu (1741. - 1748.). ${ }^{100}$ Previđajući da nije realno očekivati prikaze dalmatinskih Morlaka u seriji posvećenoj ratovima u Nje-

94 OOVD, kut. Prepiska do 1945., I., Boško Desnica - Vladanu Desnici, Obrovac, 25. ožujka 1935. Valerio da Ponte (Zadar, 1603. - Zadar, 1679.), svećenik i povjesničar. nike s terena, Boško je imao na umu potrebu za ubifikacijom mnoštva Ljubavčevih toponima kojih više nije bilo na „specjalkartama“, ali se moglo pretpostaviti da su se sačuvali u pučkoj kolektivnoj memoriji.

100 „Martin Engelbrecht (* 16. September 1684 in Augsburg; $†$ 18. Januar 1756 ebenda) war ein Kupferstecher und Kunstverleger der Barokzeit (...) Besonders bekannt ist die Engelbrechtsche Kupferstichserie aus den Jahren um 1742/45 über 'exotische' Soldaten am deutschen Kriegsschauplatz (Theatre de la milice etrangere; Schaubühne verschiedener in Teutschland bishero unbekannt gewester Soldaten von ausländischen Nationen), und hier vor allem die Panduren. Die Serie umfasst rund einhundertfünfzig Einzelblätter mit Darstellungen irregulärer Truppen aus der 


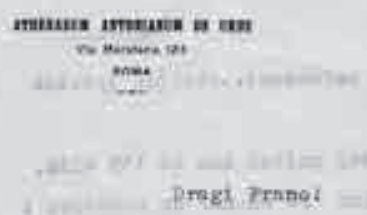

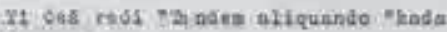
ueletak ova pitmo. I opes a thind the do ullogitm

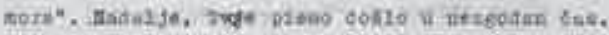

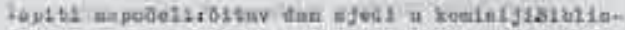

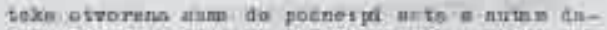

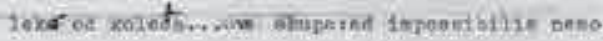

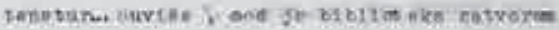

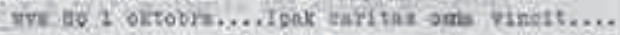

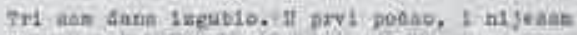

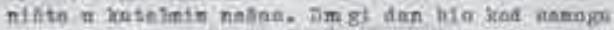

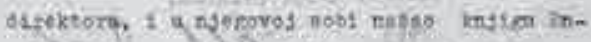
gutle eobtera. keds is edtedena z widerutaon

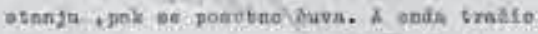

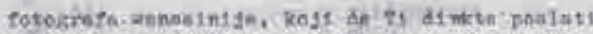

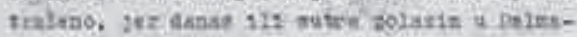

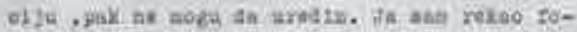

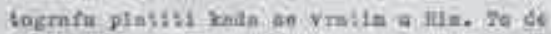

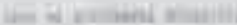

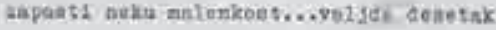

$14 \mathrm{rn} . .$.

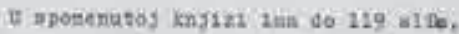

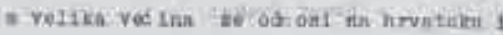

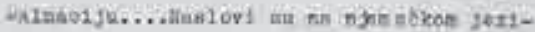

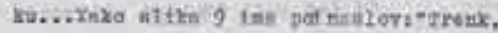

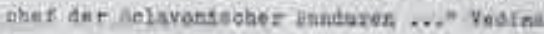

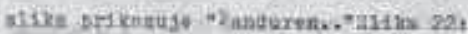

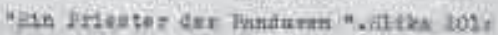

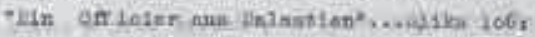

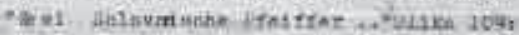

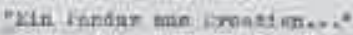

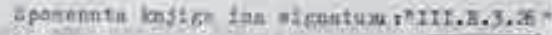

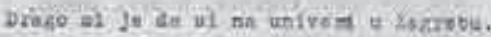
Josdrovi Gop. Liminger.

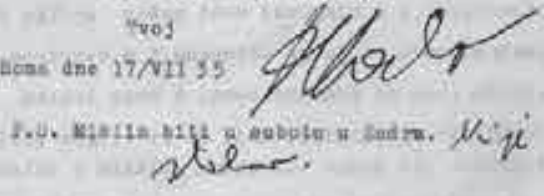

Sl. 7. Boško i Vladan Desnica u potrazi za prikazima „Morlaka“ u grafičkoj mapi Martina Engelbrechta

mačkoj, Boško i Vladan uložili su veliki napor kako bi došli do obavijesti o njoj i osigurali snimke bakroreza koji bi ih mogli zanimati. Tragali su na raznim stranama, a na koncu je Boško uspio ući u trag seriji u Rimu: „(...) Sinoć sam dobio odgovor u pogledu Engelbertovih crteža pa ti ga evo prilažem. Time otpada nužda da se za stvar obraćaš Moškatelu. ${ }^{\text {"101 }}$

Odgovor je sam po sebi bio vrlo instruktivan za razumijevanje interkonfesionalnih odnosa među starijim pripadnicima dalmatinske inteligencije jer je čovjek koji je tragao za serijom bio svećenik i, izgleda, profesor na vatikanskom Athenaeum Antonianum de Urbe. ${ }^{102}$ Kada je uskoro dobio fotografije, Barba nije mogao sakriti svoje razočaranje:

Zeit des Österreichischen Erbfolgekrieges. Neben 'Sclavonischen' Tolpatschen, Kroaten, Panduren und Haiducken sind auch einige 'Bergschotten' zu sehen. Jedes Blatt ist mit einem erklärenden Vierzeiler versehen, der häufig auf die 'Fremdheit' und 'Neuartigkeit' der dargestellten Krieger hinweist. Durch ihre 'Kostümierung' erscheinen die repräsentierten Figuren gleichsam wie von Schauspielern verkörperte Rollen. Engelbrechts Serie bediente offenbar eine besondere Nachfrage nach 'exotischem' Bildmaterial über die Akteure des damaligen Krieges und kann - die Vielzahl der Nachahmer betrachtend, die sein Werk gefunden hat - als außerordentlich erfolgreich eingestuft werden. Die Serie ist im Wiener Heeresgeschichtliches Museum ausgestellt."Vidjeti: „Martin Engelbrecht“, Wikipedia (https://de.wikipedia.org/wiki/Martin_Engelbrecht). Matija Sinko je u veljači 2012. godine obranio diplomski rad na modulu Rani novi vijek Diplomskog studija Odsjeka za povijest Filozofskog fakulteta Sveučilišta u Zagrebu pod naslovom Bakrorezi Martina Engelbrechta iz Nasljednoga rata: historijsko-imagološka analiza.

101 OOVD, kut. Prepiska do 1945., I., Boško Desnica - Vladanu Desnici, Obrovac, 18. srpnja 1935. Boško sustavno pogrešno piše prezime u formi „Engelbert“.

102 Zasad nije bilo moguće identificirati osobu koju je Boško Desnica molio za ovu uslugu, kao ni osobu („Frano“), koja je pritom posredovala. U nadi da će to biti moguće saznati, objavljujemo integralnu reprodukciju obiju strana pisma upućena iz Rima 17. srpnja 1935. Pismo se također nalazi u: OOVD, kut. Prepiska do 1945., I. 
Dobio sam iz Rima slike i šaljem ti ih na ogled gegen Rückschluss: kako vidiš čista fantazija. Morlaci, Dalmatinci, panduri i t.d. onako kako je jedan dobri Nijemac iz XVIII vijeka mislio da bi morali izgledati, po strahovitim pričama kojima je u Njemačkoj dalo života nečuveno pljačkanje: pustošenje bandita Trenka po Bavarskoj i Sleskoj. Istorijski tačnih detalja je vrlo malo. Najljepše od svega je onaj polukalabreški klobuk onog muslova! ${ }^{103}$

Boško je reagirao anticipiravši postkolonijalnu kritiku eurocentričkih imaginarija, previđajući da su bakrorezi nastali u Augsburgu u „realnom vremenu“, u vrijeme kada su Trenkovi panduri doista bili na njemačkim ratištima i da su ih mnogobrojni ljudi po zlu zapamtili, dakle da su Nijemci bili u kontaktu s ljudima koji su na bakrorezima stereotipizirani s atribucijama koje i danas zbunjuju svojim etnokarakterološkim klasifikacijskim logikama. ${ }^{104}$

Budući da je bilo nerealno očekivati da bi bilo tko mogao imati interesa uložiti novac u ambicioznije zamišljeno izdanje ovoga Ljubavčeva rukopisa, Boško i Vladan dogovorili su da Boško uz njegovu asistenciju napiše esej posvećen tome poluzaboravljenom zadarskom eruditu 17. stoljeća. Bio je to Vladanu novi povod da nastavi poticati ga kada god bi ovaj počeo posustajati. Izgleda da je Vladan nekom prilikom, htijući ubrzati rad na članku, stricu predložio da sam ode istraživati u Zadar. Time ga je izazvao da mu kaže ponešto čega Vladan u Splitu, daleko od Obrovca i Zadra, nije bio dovoljno svjestan i što nije volio priznati ni samom sebi:

Dakle, ja u Zadar ne mogu, jer bi, radi prokletstva koje lebdi nad rodom Desnica, morao da povedem ženu i djecu, lo che, tradotto in cifre, znači 2000 D. ${ }^{105}$ Osim toga trebao bi pasoše za sve jer pogranične karte neće da mi dadu, a i kad je dadu ta vrijedi za 3 dana - a to mi je malo. Pisati nekome da ti učini ekscerpt - bilo bi uzalud. Ta ko će za drugoga izvršiti tako težak i nezahvalan posao? Osim toga biblioteka je prenešena u novu općinsku zgradu, ali nije još sregjena ni otvorena publici. Dakle turi Ljubavca takva kakav je, a ako i kad dogje do toga da se opet štampa, onda ćemo ga refati. Ovgje ti prilažem sliku Foskarina, za koju mi je jedan lupež fotograf uzeo 45 D. Više neg će iznositi honorar! Schönfeld, kome sam pisao pred 15 dana, ili nije u Zadru ili je svinja, pa neće da mi pošalje slike. ${ }^{106}$ Treba dakle decampare od publikacije fotografije kuće. Conclusione: daj Masovčiću članak kakav je i slike koje si odredio - pa nek ide! ${ }^{107}$ Neću se pokriti slavom, ali me neće ni baciti na Tarpejske stijene! ${ }^{108}$

$\overline{103}$ OOVD, kut. Prepiska do 1945., I., Boško Desnica - Vladanu Desnici, Karin, [?] kolovoza 1935.

104 Ovo rano otkriće Engelbrechtove serije u nas ostalo je bez posljedica jer Boško nije iskoristio nijedan bakrorez u članku o Ljubavcu. Bolje je što to nije učinio jer su oni nastali stoljeće nakon njegova rukopisa u sasvim drugačijem sociokulturnom obzorju.

105 Boško je morao otići u fašistički talijanski Zadar s obitelji zbog sigurnosnih razloga. Desnice su 1918. - 1920. bile među onima koji su prednjačili vodeću jugoslavensku aneksionističku politiku u Zadru i Sjevernoj Dalmaciji pa su obojica bila 1919. internirana u Italiji, a 1920., nakon povratka, faktički prisiljena napustiti grad. Vidjeti: Drago RoKsANDIĆ, „Dr. Uroš Desnica 1918. - 1921.: životopisne nedoumice na raskrižju epoha“, Spalatumque dedit ortum. Zbornik povodom desete godišnjice Odsjeka za povijest Filozofskog fakulteta u Splitu (ur. Ivan Basić i Marko Rimac), Split 2014., $499-511$.

106 „Schönfeld, Enrico (1873 - 1942). Zadar. Dugogodišnji i najistaknutiji zadarski knjižar, nakladnik, tiskar i prodavač fotografske opreme i materijala. Bez dvojbe podjednako najveći i najugledniji izdavač zadarskih razglednica. Naslijedio je obiteljsku knjižaru koja je poslovala na Narodnom trgu, zapadno od zgrade broj 5, najkasnije od 1880, a tiskaru je otvorio 1907. u Ulici Svete Marije, sučelice ulazu u Samostan. Stradala je u bombardiranju Grada 1943/44. Objavio je prvu zadarsku razglednicu 1892.“ Vidjeti: „Potraga za građanskim identitetom. Razglednice i kavane“ (http://zadaretro. info/identitet/razglednice\%20i\%20kavane/razgled_i_kavane.htm).

107 Ante Masovčić (1889. - 1948.). Inače, jedan od najboljih portreta u modernom hrvatskom slikarstvu, „Bonvivant“ Miroslava Kraljevića (1912.), ustvari je portret Ante Masovčića. Vidjeti: „Povijesno otkriće. Kraljevićev Bonvivant prvi je hrvatski filmski redatelj Arsen Maas“, Jutarnji list (http://www.jutarnji.hr/kultura/film-i-tv/povijesno-otkrice-kraljevicev-bonvivant-prvi-je-hrvatski-filmski-redatelj-arsen-maas/856621/).

108 OOVD, kut. Prepiska do 1945., I., Boško Desnica - Vladanu Desnici, Obrovac, 29. srpnja 1935. Ante Masovčić objavio je Boškov članak u prvom broju novopokrenutog, ali i kratkotrajnog Glasnika Primorske banovine: izdanje Službenog glasnika Primorske banovine. 
Bio je to preuranjen nalog jer je Boško vlastitom voljom ili reagirajući na Vladanove poticaje nastavio raditi na Ljubavčevu rukopisu čak tri sljedeće godine. Sudeći prema iskazu u članku o Ljubovcu, osigurao je kontrolnu usporedbu svoga zadarskog prijepisa s vjerojatnim originalnim rukopisom u Muzeju Correr u Veneciji. ${ }^{109}$ Što se više njime bavio, više se distancirao od njegove erudicijske kulture:

A sad na Ljubavca. Ti, čini mi se, precjenjuješ vrijednost radnje. Sad, kad sam je dovršio, stvar mi izgleda mršava intrinsecamente ed estensivamente. Rekao sam sve što sam mislio i imao da kažem a nije ispalo neg 17 stranica. Što se ilustracija tiče, ja bi imao samo jednu piantu Zadra iz XVII vijeka, koju ću potražiti i priložiti, za sliku kuće pisaću Schönfeldu, za grb bi ti mogao vidjeti ima li ga u Hegerovu Wappenbuchu u gradskoj ili muzealnoj biblioteci, jer inače ne znam od kud bi ga dobio. ${ }^{110}$ Drugih ilustracija ne bi mogao da škaturim. Možda jedino fotografija Foscolova portreta iz manastira Sv. Lovre koju ti takogjer prilažem. Dunkve, dragi moj, evo ti sve pa ti čini što i kako znaš. Najprije pročitaj rukopis pa ga korigiraj i dižinfetaj po tvom ukusu i miloj volji, naročito ortografiju u kojoj nisam puno potkovan. Ako misliš da će se sa rukopisa teško štampati, daj o mom trošku otkucati, pobrini se za prvu i sve susljedne korekture, jednom riječi čini sve što i kako znaš, jer imaš i više prakse i više znanja od mene. ${ }^{111}$

Kada bismo mogli pronaći Boškov izvornik i usporediti ga s objavljenim tekstom, uspjeli bismo odgovoriti i na pitanje kakav je i koliki bio Vladanov udio u finaliziranju rukopisa. Kako to sada nije moguće, ovo Boškovo pismo nesumnjivo opravdava daljnja traganja. Napore u tom smislu opravdava još jedno Boškovo pismo koje je vjerojatno nastalo poslije prethodno citiranog:

Meni se, a lettura definitiva, Ljubavac sve to manje dopada. Mislim da ne bi bilo smisla da se troši za posebno odštampavanje tim manje što honorar neće pokriti trošak, pa bi trebalo nadoplaćivati - a meni - Bogami - nije do toga. Ako možeš da iskamčiš od Masovčića koji posebni otisak, niente de meo, ako ne možeš lascia correr! ${ }^{112}$

Ovo je pismo još jedan dokaz da je Vladan bio taj koji je komunicirao sa spomenutim Masovčićem u vezi s objavljivanjem Boškova rada i rješavao čitav niz praktičnih problema koji su bar dijelom mogli biti i sadržajne naravi.

Ante Masovčić objavio je ovaj članak Boška Desnice u novopokrenutom, grafički atraktivnom Glasniku Primorske banovine. ${ }^{113}$ Članak je bio raskošno opremljen s čak 12 ilustracija, najvećim dijelom reprodukcija karata, vinjeta i portreta u bakrorezu iz 17. stoljeća. ${ }^{114}$

\footnotetext{
109 Budući da je Vladan 1937. bio u Veneciji, ne bi trebalo isključiti mogućnost da je on kolacionirao Barbin zadarski prijepis Ljubavčeva rukopisa sa spomenutim originalom u Muzeju Correr.

110 Vidjeti: Johann Siebmacher, Das erneuerte und vermehrte Teutsche Wappenbuch: in welchem deß H. Römischen Reiches hohe Potentaten, Fürsten, Grafen, Herren, Freyherren, Edle Stände und Städte, etc. Wappen, Schilde, Helm, Kleinodien, Wie auch Deroselben Namen, Herrschafften, und HeroldsFarben, etc. außgebildet zuersehen, Nürnberg 1667.

111 OOVD, kut. Prepiska do 1945., I., Boško Desnica - Vladanu Desnici, Obrovac, 13. srpnja 1938.

112 OOVD, kut. Prepiska do 1945., I., Boško Desnica - Vladanu Desnici, Obrovac, „konac 1938.“. Vladan je naknadno upisao vrijeme slanja pisma. Prije će biti da je pismo napisano u kasno ljeto jer je članak bio objavljen ujesen iste godine.

113 Boško Desnica, „Zadranin Šimun Ljubavac. Jedan dalmatinski erudit XVII vijeka“, Glasnik Primorske banovine, 1/1938., br. 1, 173-181.

114 Uvrštene su sljedeće reprodukcije: Ivan Lučić, Zadar u XVI. vijeku (G. Sabalich), Sjeverna Dalmacija (Coronelli /1688./), Polišnik, Karin, Islam, Nadin, Obrovac, Novigrad, prov. Leonardo Foscolo, prov. Girolamo Foscarini i Frano Difnico. Kada se ovaj popis usporedi s popisom slikovnih priloga koje je Barba bio osigurao, realno je pretpostaviti da ih je većinu izabrao i pribavio Vladan. Baveći se Ljubavcem, Barba i Vladan su, htijući to ili ne, s konceptualne subregionalne problematike otišli u sfere „mediteranske euritmije duha“!
} 
Bio je to ustvari materijal koji je trebao biti iskorišten za neostvareno izdanje Ljubavčeva rukopisa, koji, nota bene, još uvijek u hrvatskoj historiografiji nije kritički objavljen.

Iako se ne može reći da je Šimun Ljubavac danas nepoznat u hrvatskoj kulturnoj povijesti ranoga novog vijeka, Boško Desnica je još uvijek jedini koji mu je posvetio poseban esej. Napisao ga je s neskrivenom empatijom za čovjeka velikih znanja koji je zadužio Ivana Lučića i trajno bio i ostao u njegovoj sjeni, ali i za čovjeka kojeg je doživio kao arhetip modernoga dalmatinskog intelektualca:

Ljubavac nije za života objavio štampom ni jedno svoje djelo. Neobično skroman i povučen, on je radio radi zadovoljstva koje mu je taj rad pričinjao, radio je da ispuni svoje građanske i podaničke dužnosti, radio je, najzad, nesebično i predano da bi pomagao u radu svoje prijatelje, naročito onog ćudljivog i sebičnog Lučića, koji ga je bezobzirno naučno iskorišćavao, a koji je, i pored svog superiornog stava, mnogo držao do Ljubavčeva mišljenja i njegov sud o svojim djelima očekivao „con ansietà grande“. (...) Šimun Ljubavac nije bio istoričar Lučićeva duha. On nije dao ni jedne radnje koja bi ni izdaleka mogla da se uporedi sa epohalnim Lučićevim djelom; on je dao samo nekoliko savjesnih i dobrih priloga domaćoj geografiji i istoriografiji. Sa te tačke gledanja Ljubavcu se može da prizna samo jedan osrednji naučnički stas, ali posmatran kao figura, u čitavom sklopu svoga života i rada, svoje kulture i uljuđenosti, svoje građanske, profesionalne i naučne djelatnosti, Ljubavac predstavlja arhetip dalmatinskog erudita svog vremena, arhetip one specifične mediteranske euritmije duha, kulture, ukusa i čestitosti, čiji posljednji pretstavnici iščezavaju pred našim očima, jedan po jedan. ${ }^{115}$

Dakle, Boško se na kraju uopće nije bavio nastankom modernog koncepta Sjeverne Dalmacije, kao ni pojmom Contado e Territorio di Zara, t. j. onim zbog čega se upustio u zahtjevno istraživanje rukopisa Šimuna Ljubavca, kao i njegova opusa u zadarskoj i dalmatinskoj intelektualnoj kulturi 17. stoljeća. Zanijela je i njega, kao i više drugih, narav odnosa između Ivana Lučića i Šimuna Ljubavca, što je važna tema, ali ne toliko važna da bi potisnula neke druge kao što su teme vezane za povijest Dalmacije shvaćene kao povijesti međuodnosa njezinih inzularnih, litoralnih i kontinentalnih dijelova. Pomicanjem mletačkih granica od acquisto vecchio na acquisto nuovo u vrijeme Kandijskog rata to je postao jedan od ključnih problema njezina daljnjeg razvitka, ali i razumijevanja njezine povijesti u dugom trajanju. Bio je to zadatak koji je prelazio granice onoga što je Barba mogao učiniti, a Vladan se „umjetničkim istinama“ triju Dalmacija nikada nije prestao baviti, kako prije, tako i poslije Zimskog ljetovanja. Rukopis Šimuna Ljubavca i iskustvo rada s Barbom na tom rukopisu bio je svojevrstan korisni katalizator u razvijanju interesa za sociokulturnu cjelinu zadarske regije u 17. stoljeću.

115 B. Desnica, „Zadranin Šimun Ljubavac“, 181. Slične formulacije upotrijebio je Barba govoreći o Josipu Bersi. Vidjeti citat uz bilj. 77. Bile su to varijacije na teme o kojima je u $M S D$-u 1934. pisao Vladimir Rismondo. 


\section{Desničin povratak Croceu uoči Drugoga}

\section{SVJETSKOG RATA}

Prema većini Desničinih biografa, Vladan Desnica ništa nije tiskao nakon izlaska iz tiska $M S D$-u 1935. i objavljivanja njegova prijevoda Croceovih Eseja iz estetike 1938. Pritom obično propuštaju spomenuti da je jedan od prevedenih eseja bio tiskan u splitskom Vihoru, inače ljotićevskom glasilu, koji je uređivao splitski književnik Marin Bego (1881. - 1960.) Nedoumicu može izazvati to što prijevod nije potpisan i što inače nema nikakva spomena Desničina imena u ovom listu. ${ }^{116}$ Budući da se Vihor ni jednom riječju nije oglasio ni nakon što su Eseji bili objelodanjeni, nameće se zaključak da je Desničina suradnja u njemu bila moguća stjecajem trenutačnih okolnosti.

Moguće je pretpostaviti da je pokušao i na nekim drugim stranama u Splitu osigurati najavu svog izdanja, ali da u tome nije uspio. Slijedom iste pretpostavke moguće je da mu je Vihor ponudio promotivni prostor, a da on nije htio propustiti šansu da se makar i na taj način koliko-toliko potakne interes za njegov prijevod Crocea. $S$ druge strane, otvoreno ostaje pitanje zašto se nije htio svojim imenom svrstati među suradnike Vihora. Budući da je Benedetto Croce u to vrijeme već bio postao europski simbol liberalne kontestacije u fašističkoj Italiji, nikako nije više mogao biti atraktivan za list poput Vihora. Neobično je što je taj prijevod u njemu uopće objavljen!

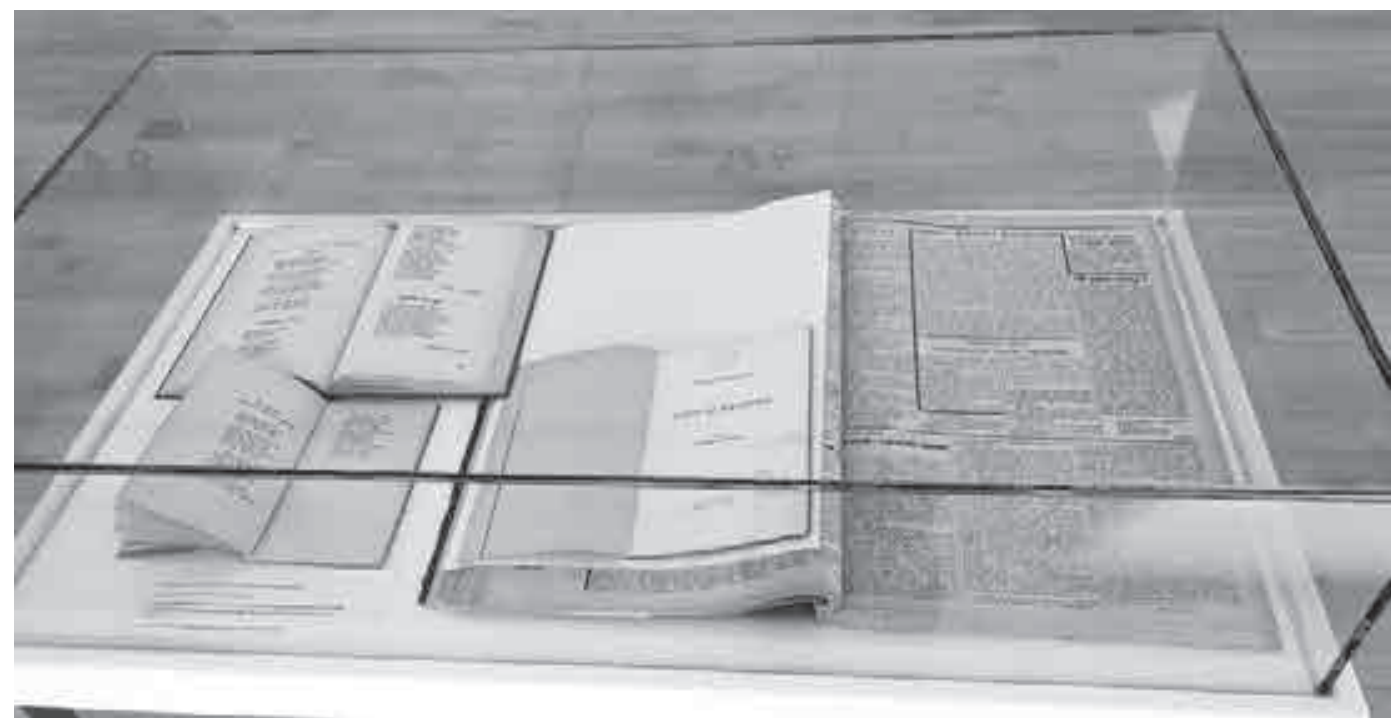

Sl. 8. Benedetto Croce u prijevodu Vladana Desnice u splitskom Vihoru urednika Marina Bege i vlastitoj nakladi Kadmos 1938.

Kako god bilo, sačuvan je materijalni dokaz da Vihor nije financirao objavljivanje Eseja iz estetike, a to je originalni račun tiskare u kojoj su Eseji tiskani. Troškove je podmirio Vladan Desnica sam, a rukopisni listić u prilogu, koji je potpisala ista ovlaštena osoba u

$\overline{116}$ Benedetto Croce, „Čista intuicija i lirski karakter umjetnosti“, Vihor, 2/1938., br. 19, 3. 
tiskari, svjedoči da je Vihor dobio pet primjeraka otisnute knjige, što je prema pojedinačnoj tiskarskoj cijeni primjerka mogao biti iznos honorara koji mu je list dugovao.

Dakle, za nakladu od 1000 primjeraka Vladan Desnica je platio 4000,- Din, tj. tiskarska cijena jednog primjerka bila je 40,- Din. Kako je on u to vrijeme uputio najavu ovog izdanja na razne novinske adrese, koja je također sačuvana, znamo da je prodajna cijena 1 primjerka bila 15.- Din. To znači da je po svakom prodanom primjerku bio na čistom gubitku od 25.- Din! ${ }^{117}$ Jednom riječju, bio je to pravi promašaj s poslovne strane. Izdanje je bilo promašaj i na knjižarskom tržištu. Javno je praktički bilo ignorirano. Nešto sadržajnija obavijest o izlasku ove „knjižice“ (Büchlein) izašla je u Prager Presse, koja je ranije bila pisala i o $M S D$-u. ${ }^{118}$ Sačuvano je svjedočanstvo o interesu utjecajnoga slovenskog književnog kriti-

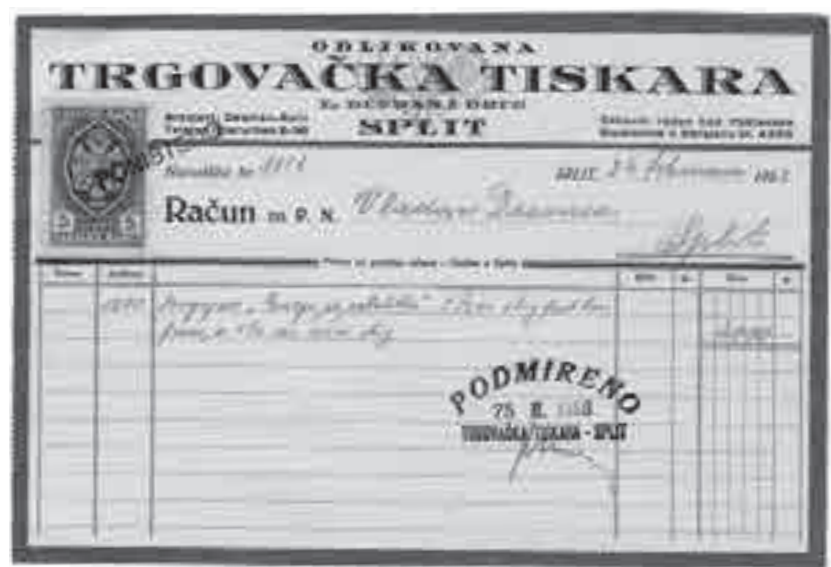

Sl. 9. Vladan Desnica plaća Trgovačkoj tiskari u Splitu 24. veljače 1938. tiskarske troškove za Croceove Eseje iz estetike

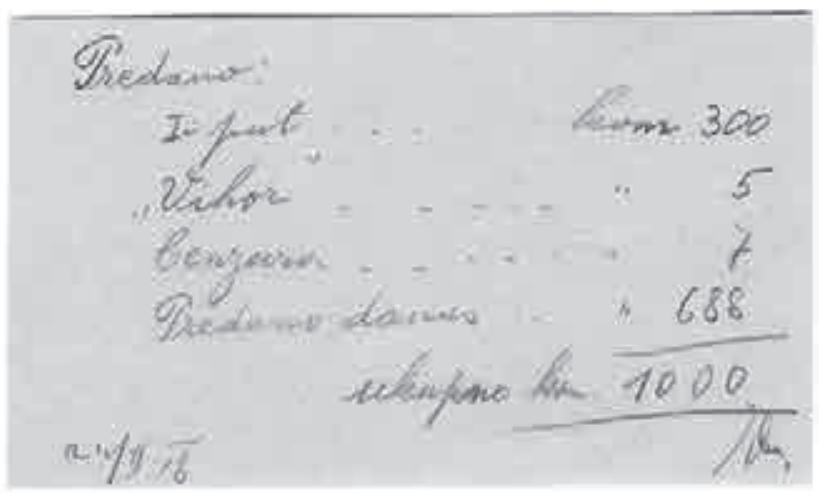

Sl. 10. Distribucijska lista iz Trgovačke tiskare za 1000 primjeraka Croceovih Eseja čara tog doba, Božidara Borka (1896. - 1980.), za Desničino izdanje Crocea. Borko se sam javio na adresu Naklade „Kadmos“ 28. veljače 1938., potpisavši se kao urednik ljubljanskog Jutra, s molbom da mu se „odmah“ pošalje primjerak Eseja. Pritom se obvezao da će sam nadoknaditi cijenu knjige i poštanske troškove. ${ }^{119}$ Ne treba sumnjati da mu je Desnica

117 Sačuvan je tekst tog oglasa: „S molbom da uvrstite u nekoliko brojeva Vašeg cij[enjenog] lista: BENEDETTO CROCE: ESEJI IZ ESTETIKE, preveo VLADAN DESNICA. Sadrži odabrane eseje u kojima Croce dalje razvija i produbljuje svoju doktrinu izloženu u 'Estetici': I. Čista intuicija i lirski karakter umjetnosti; II. Umjetnost kao stvaranje i stvaranje kao činjenica; III. Vanestetski pojam lijepoga i njegova upotreba u kritici; IV. Književnost kao izraz društva. Cijena din. 15:- Naručuje se kod 'KADMOS' - Split, Bihaćka 5." OOVD, kut. Prepiska do $1945 .$, I. Politika je objavila oglas 27. veljače 1938., a Vreme 1. ožujka iste godine, oba lista među malim oglasima.

118 „Vier Essays Benedetto Croces zur Aesthetik hat in serbokroatischer Uebersetzung Vladan Desnica veröffentlicht: 'Eseji iz estetike', Split 1938, 8 65 S. 15 Dinar, Verlag Kadmos. Das Büchlein enthält vor allem B. Croces Aufsatz über den lyrischen Charakter der Kunst (1908), ferner Aufsätze über Kunst als Schöpferisches, über den außerästhetischen Begriff des Schönen und seine Anwendung in der Kritik, sowie einige Seiten über Kunst als Abbild der Gesellschaft. An dieser Stelle sei bemerkt, dass B. Croces 'Aesthetik' bereits vor Jahren serbokroatisch erschienen ist. (Estetika. Preveo d-r Vinko Vitezica. Beograd 1934. Kosmos)“ Vidjeti: OOVD, kut. Prepiska do 1945., I., Prager Presse, 25. März 1938., Seite 8.

119 OOVD, kut. Prepiska do 1945., I., Božidar Borko - Naklada „Kadmos“, Ljubljana, 28. veljače 1938. 
odmah poslao recenzentski primjerak i potom, zaveden Borkovim „odmah“, u Splitu je iz dana u dan pratio ljubljansko Jutro. Nije dugo izdržao jer je već 9. ožujka t. g. pisao Borku:

Na Vašu dopisnicu od 28/II poslali smo Vam na poklon primjerak knjige „CROCE, ESEJI IZ ESTETIKE“ s molbom na uvrštenje priložene notice i na eventualni prikaz u Vašem cij[enjenom] listu. No kako u stupcima vašeg lista nismo naišli na spomen o knjizi, molimo Vas da nam javite ako Vam slučajno nije stigla, kako bismo mogli da vam pošaljemo drugi primjerak. ${ }^{120}$

Zatečeni Borko odmah mu je ljubazno odgovorio, s uočljivom notom nevjerice da čovjek od knjige može biti toliko nestrpljiv:

Zahvaljujem Vam za ljubazni poklon primjerka knjige Croce, Eseji iz estetike. Vrlo rado ću objaviti o knjizi opširniji prikaz i tako svrnuti na nju pažnju slovenačke javnosti. Radi obilja aktualnog materiala za moju rubriku nisam to mogao učiniti odmah, ali se nadam da će članak s preporukom izaći u toku naredne nedelje. Primjerak tog broja poslat ću Vam odmah čim izadje. ${ }^{121}$

U Desničinoj ostavštini nije sačuvan Borkov prikaz, a ni u Bibliografiji Leksikografskog zavoda Miroslav Krleža nismo uspjeli pronaći nikakav trag tom tekstu pa ostaje otvoreno pitanje je li Borko održao zadatu riječ. Za razliku od njega, nitko drugi slična statusa nije se oglasio bilo na hrvatskoj bilo na srpskoj strani. Desničin Croce jednostavno je prešućen. Tim su dirljivije reakcije njegovih nekadašnjih profesora i prijatelja iz mladosti kojima je na poklon poslao primjerak izdanja.

Prvi se oglasio njegov gimnazijski profesor dr. Mirko Perković, s kojim je obnovio veze već u vrijeme pokretanja $M S D-a$. Ni ovom prilikom nije štedio pohvale:

Dragi Vladane!

Od srca Ti hvala na lijepom daru! Pročitao sam, pa mi se prijevod vrlo sviđa, jer bih rekao da si pogodio - a i uspio - da zadržiš stil Croce-ov, a opet nisi se nigdje spotaknuo o naš stil. Samo bih ja, kao „nepopravljivi“ Vukovac, prigovorio onome sklanjanju naših participa! (Na pr. „bježućem času“; str. 33). Imam u svojoj biblioteci njegovu veliku „Estetica come scienza dell'espressione..." od 1908. i na franc[uskom] „B[enedetto] C[roce] Bréviaire d'esthétique", traduction de G. Bourgin, Paris 1923, a sad i tvoj uspjeli prijevod. Drugih njegovih djela nemam. Bratski te pozdravlja tvoj Dr. M[irko] Perković - Knin ${ }^{122}$

Prijateljski se prvi javio neidentificirani splitski Beograđanin „Pero“, 3. ožujka 1938., s kojim se evidentno odavno poznavao:

Dragi Vladane,

Nameravao sam da pročitam, pa da ti, blagodareći, izrazim i svoje utiske. Međutim, nisu Eseji još stigli na stol (jer moram da dovršim Huxley-a) pa ti kažem, ne dangubeći, hvala na pažnji i lepom poklonu. Po rukopisu možeš da vidiš koliko sam „u priši“ zbog nekih akata, običnih i dosadnih ali hitnih. Nadam se da ste svi zdravi i veseli i da ste se savršeno snašli

\footnotetext{
$\overline{120}$ OOVD, kut. Prepiska do 1945., I., Vladan Desnica - Božidaru Borku, Split, 9. ožujka 1938., nepotpisana strojopisna kopija.

121 OOVD, kut. Prepiska do 1945., I., Božidar Borko - Vladanu Desnici, Ljubljana, 12. ožujka 1938.

122 OOVD, kut. Prepiska do 1945., I., Mirko Perković - Vladanu Desnici, Knin, 20. veljače 1938.
} 
u novoj ulozi splitskih kućevlasnika. Mojoj staroj reci da si primio ove retke, te ima mesta verovanju da sam živ. Sve vas najsrdačnije pozdravlja, u mnogo čemu zavidi i iskreno voli tvoj vršnjak,

$$
\text { Pero }^{123}
$$

Drugi je reagirao jedan od njegovih profesora sa splitske Klasične gimnazije, koji mu je 8. ožujka 1938. poslao dopisnicu s karikaturom neke osobe na prednjoj strani, sudeći prema naglascima, karikaturi profesora samog:

Dragi i poštovani prijatelju:

Hitam da Vam srdačno zahvalim na priposlanom mi lijepom daru. Pročitao sam na dušak i mogu Vam čestitati na izvrsnom prijevodu.

„Vivas votis meis“

U ljubavi i u odanosti

prof. $(. . .)^{124}$
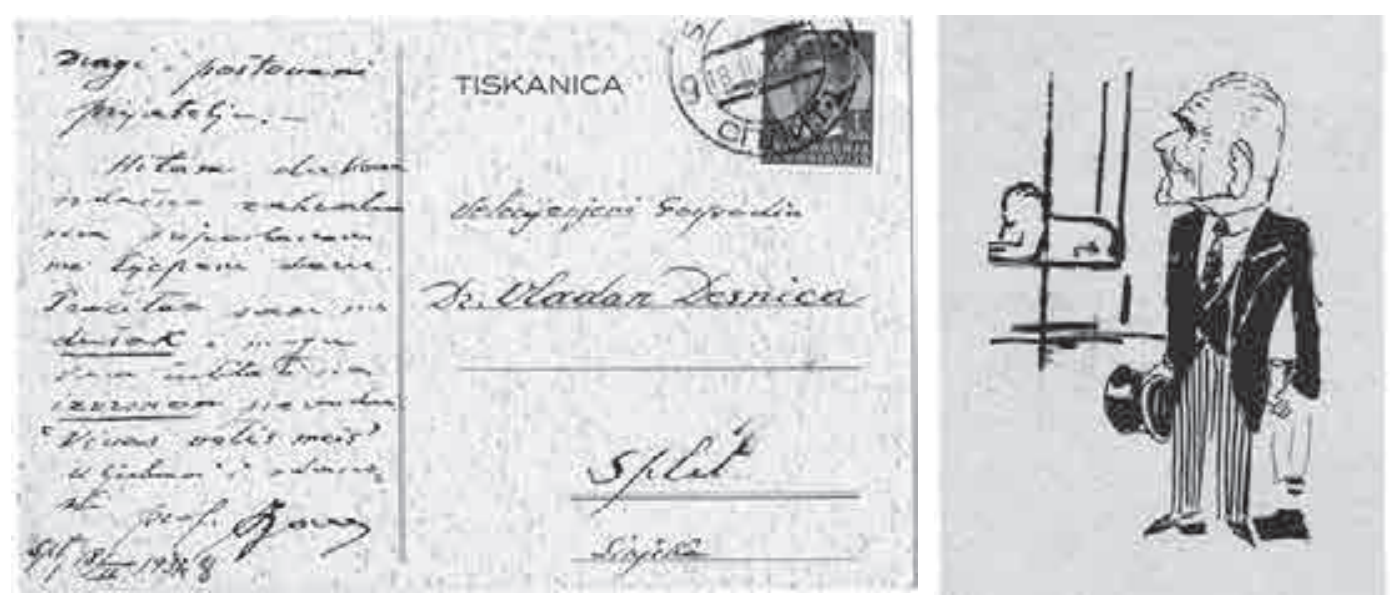

Sl. 11. Zahvala splitskog profesora Vladanu Desnici na prijevodu Croceovih Eseja iz estetike

Podrška je stigla i od jednoga od najutjecajnijih splitskih intelektualaca starije generacije i njegova profesora na Klasičnoj gimnaziji, dr. Ante Petravića:

Dragi Vladane!

Primio sam tvoju knjigu i zahvaljujem ti na sjećanju. Inače ja imam te stvari (desetak svezaka Crocea) u originalu. Zanimat će me poređivati s originalom.

Srdačno pozdravlja Troj

Ante Petravićc ${ }^{125}$

$\overline{123}$ OOVD, kut. Prepiska do 1945., I., Pero [Zanella] - Vladanu Desnici, Beograd, 3. ožujka 1938. Prema iskazu dr. Uroša Desnice, mogao bi to biti Petar Zanella, Splićanin koji je u to vrijeme radio u Beogradu. Srdačno mu zahvaljujem na obavijesti.

124 OOVD, kut. Prepiska do 1945., I., [?] - Vladanu Desnici, Split, 8. ožujka 1938.

125 OOVD, kut. Prepiska do 1945., I., Ante Petravić - Vladanu Desnici, 8. ožujka 1938. Profesor Petravić je Vladana u adresi oslovio kao književnika. 
Prijateljski mu je zahvalio i prezimenom neidentificirani Makaranin Eugen, također netko koga je dobro poznavao. Njegova je poruka zanimljiva i zbog toga što ga intrigira fenomen Naklade Kadmos. Jasno mu je da je to inicijativa Vladana Desnice:

Dragi Vladane,

Pred nekoliko dana primio sam „Eseje estetičke“. Ako „Kadmos“ treba zahvaliti tvojoj inicijativi, onda je toplo „pozdravljam“.

Uvjeren sam, da ćeš ti „Kadmosu“ doprinesti bogatstvo tvoga duha i dati mu širinu svojih vidika.

Doista je kulturnom Splitu nedostajala jedna takva edicija.

Mnogo uspjeha želim „Kadmosu“.

Primi srdačne pozdrave od tvoga

Eugena $^{126}$

Šibenski Vlado, očito prijateljski i obiteljski blizak čovjek, reagirao je kao netko tko je znao njegove intimne nedoumice i lomove:

Dragi Vladane, najljepša Ti hvala na knjizi i pažnji. Drago mi je da se boriš i da aktivno daješ dokaza da radiš na knjiž[evnom] polju. To ti je mnogo pametnije nego što drugo.

Danas idemo u Obrovac, pozvao nas je Boško na neku fraju, ide nas 18 komada!

Nadam se sa koncem mjeseca da ćemo se viditi u Splitu.

Od Gabi i od mene Kseniji i Tebi mnogo srdačnih pozdrava.

Grli te Tvoj Vlado. ${ }^{127}$

Zahvalio mu je i Dušan Manger, u Splitu cijenjeni ravnatelj Gradske biblioteke na poklonjenom primjerku za Biblioteku. ${ }^{128}$

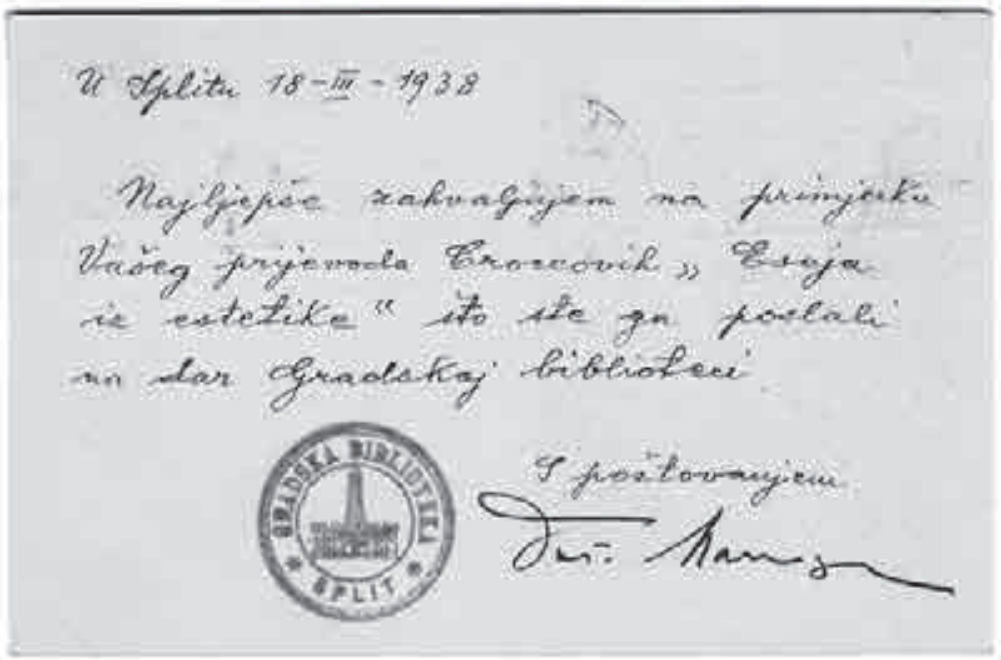

Sl. 12. Ravnatelj Gradske knjižnice u Splitu Dušan Manger Vladanu Desnici 1938.

\footnotetext{
$\overline{126}$ OOVD, kut. Prepiska do 1945., I., Eugen [?], Makarska, 10. ožujka 1938.

127 OOVD, kut. Prepiska do 1945., I., Vladimir Simić, Šibenik, 23. ožujka 1938. Informaciju mi je dala gsopođa Jelena Ivičević-Desnica. Srdačno joj zahvaljujem.

128 OOVD, kut. Prepiska do 1945., I., Dušan Mangjer - Vladanu Desnici, Split, 18. ožujka 1938.
} 
Među sačuvanim pismima u vezi s Croceovim Esejima svojom važnošću nesumnjivo se izdvajaju dva koja potječu od Bogdana Radice. On je tada slovio za najboljeg poznavatelja i prevoditelja Croceova opusa. Bio je jedini iz Jugoslavije koji ga je i osobno dobro poznavao. ${ }^{129}$

Ne ulazeći na ovome mjestu u razne aspekte Radičinih pisama, razumljivo je što je napisao da bi mu bilo draže da je Desnica objavio više drugih neprevedenih Croceovih radova, naročito „ceo Brevijar Estetike“. Radica, dakako, pritom nije ni pomislio

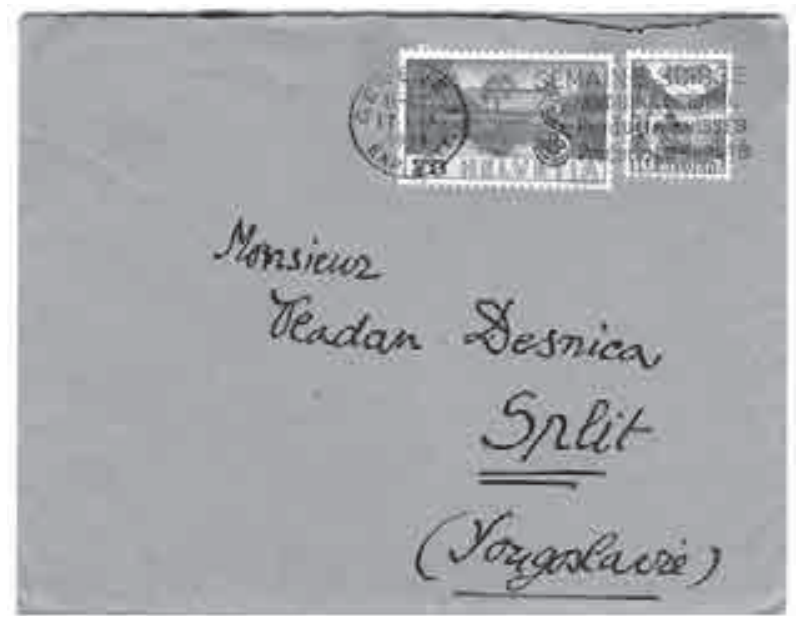

Sl. 13. Omotnica pisma Bogdana Radice Vladanu Desnici iz 1938. koliko je Desnicu stajalo izdanje koje je realizirao. Vjerojatno je i sam bio mišljenja da je obitelj Desnica toliko bogata da si ovakav luksuz može bez oklijevanja priuštiti.

$\mathrm{Za}$ istraživača Desničina stvaralaštva prije 1941. godine dragocjena je spoznaja da je molio Radicu neka mu kaže svoje mišljenje o smislenosti i održivosti prijevoda Croceove Storia d'Europa nel secolo decimonono (1932.) jer je poznato da je Desnica radio na tom prijevodu. Otvoreno je pitanje jesu li oni s tim prijevodom u vezi i dalje kontaktirali. Ovdje je bitno uočiti da zahvaljujući ovim pismima saznajemo da Vladan Desnica tada više nije bio sklon dalje prevoditi Croceove estetičke spise, ali jest historiografske.

Jedan od razloga Desničinu prevoditeljskom otklonu od estetičkih ka historiografskim Croceovim radovima mogao je biti posljedica nakladničkog debakla s Esejima iz estetike. Prema sadašnjim uvidima, u Desničinoj ostavštini nalazi se samo jedan sadržajniji osvrt na ovo izdanje. ${ }^{130}$ Danas je interesantan kao svjedočanstvo da se splitske kročeance nazivalo uistinu primjerenije „mediterancima“ i da je Vladan Desnica već tada „pored Dr. A. Halera“ bio cijenjen kao „najbolji poznavaoc Croceovih djela u Dalmaciji“:

G. Vladan Desnica, sudionik mediteranaca iz Splita (gg. Ćiro Čičin Šain, Ante Cettineo, L. [sic!] Rismondo, C. Fisković) dobro je uradio što je preveo ovih par Croceovih eseja i što je tim prevađanjem dao povoda razmišljanju postavljenog problema o estetici kao čistoj intuiciji i sociologiji umjetnosti. Pored Dr. A. Halera g. Desnica je najbolji poznavaoc Croceovih djela u Dalmaciji i kao takav mogao je da u uvodu ovih prevedenih eseja kritički osmotri Croceov rad na području estetike, pošto je uvodni članak Croceovoj estetici prevedenoj u Beogradu, uglavnom informativne naravi podupirane sporadičnim napomenama i zaključcima koji su se dali izvući sa stanovišta prevađaoca iz Croceove intelektualne kućerine. ${ }^{131}$

\footnotetext{
129 Vidjeti Prilog I.

130 Š[ime] V[UČETIĆ], „G. Vladan Desnica prevađa B. Crocea“, Naši dani. List za kulturna pitanja i književnost (ur. Marin Franičević), 1/1938., br. 1, 29-31. Sudeći prema sadržaju, Naši dani bili su svojevrsni daljnji srodnik MSD-a.

131 Isto. Kritički se distancirajući od Crocea, Vučetić je zaključio svoj osvrt riječima priznanja, punima nespokoja: „Tako je Croce predvidio sasvim slučajno i 1914. i sve što se dogodilo do danas na terenu na kome je cvjetala zapadnoevropska civilizacija“.
} 


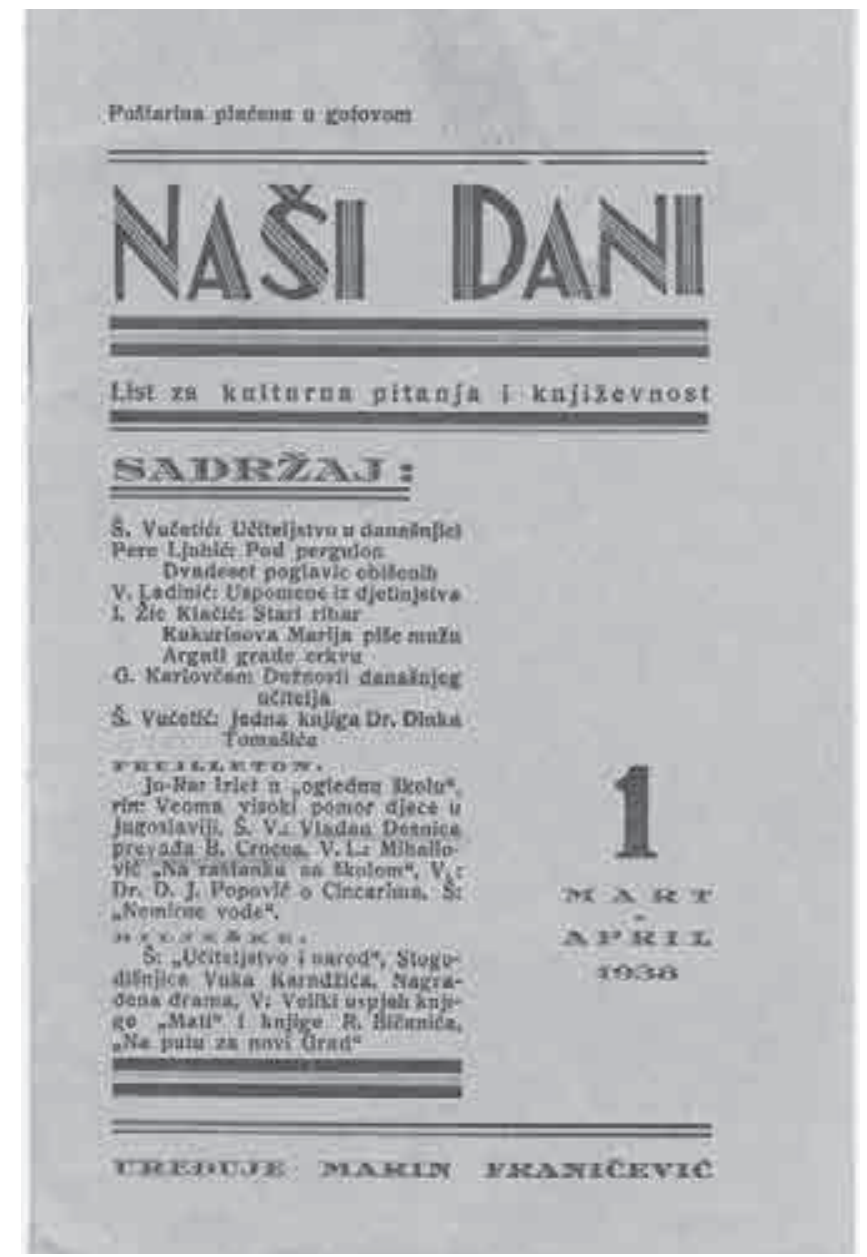

Sl. 14. Naši dani Marina Franičevića o Desničinu prijevodu Crocea

Drugi je bio u dalekosežnijoj vezi s njegovim književnim planovima. Mnogobrojne stričeve konkretne opaske u vezi sa „Životnom stazom Jandrije Kutlače“ morale su ga definitivno uvjeriti koliko mu je važno razviti umijeće povijesnog mišljenja da bi bio književnik kakav je htio postati. Za njega to nije bio contradictio in adjecto. Razumije se da ga profesionalna ideologizirana historiografija nije ushićivala, nerijetko ju je i ironizirao, ali je itekako mogao biti motiviran razumjeti Croceov, pa i Silvin pristup europskoj povijesti. Bili su to pristupi koji su mu otvarali put prema historiografskim istinama, nezaobilaznima u potrazi za umjetničkim istinama.

\section{ZAKLJUČAK}

U ovom prilogu pošli smo od pretpostavke da se Vladan Desnica kasnih 1930-ih godina - prestavši uređivati Magazin Sjeverne Dalmacije (1935.) i počevši pisati Proljeća Ivana Galeba (1936.) - odlučio radikalizirati svoje opredjeljenje da se posveti traganjima za „umjet- 
ničkim istinama“, slijedeći u osnovi kročeansko poimanje lijepog i istinitog. Koliko god to značilo prekid s kulturološkim pa i estetičkim implikacijama koncepcije Magazina Sjeverne Dalmacije - naročito kada je riječ o regionalističkim implikacijama kulture i, posebno, umjetnosti - itekako je i dalje držao važnim shvatiti režim drugih istina čovjeka o sebi, drugima, svijetu, prirodi itd., koje su u regionalno osmišljenim studijama jedino i mogle dolaziti do svoga punog izražaja. Stoga je za njega razumijevanje drugih ljudskih istina bilo nužan preduvjet traganja za umjetničkom istinom o istim tim ljudima.

Uređivanje Magazina Sjeverne Dalmacije otvorilo mu je prostor izravne komunikacije sa znanstvenicima različitih profesionalnih specijalizacija. Sačuvana korespondencija svjedoči da je kao mlad čovjek bio sposoban steći njihovo povjerenje i u više slučajeva izazvati živ interes onih koji ga nisu osobno poznavali za susret s njime. Ona je svjedočanstvo i o tome da je Vladan Desnica razvijao živ interes za inovacije u društveno-humanističkim, pa i prirodoznanstvenim istraživanjima (npr. u sociologiji i antropologiji te socijalnoj medicini).

Prividno je paradoksalno da se njegov aktivni interes za arhivistički utemeljenu kritičku historiografiju povećavao nakon 1935. godine. Tome su manjim dijelom mogli biti razlog politički i kulturni konflikti koje nije mogao izbjeći kao urednik Magazina Sjeverne Dalmacije, a koji su ga kasnije osobno tangirali. Mnogo je važnije to što kročeanska estetika nije bila ahistorička i što je, s estetičkom legitimacijom u vezi, in patrimonio baštinio živ interes za povijest i za historiografska istraživanja. Njegov stric Boško od svoje se mladosti pasionirano bavio arhivskim istraživanjima fokusiranima na Ravne kotare, Bukovicu i Zadar te je u kasnim 1930-im godinama pokušavao finalizirati svoj magnum opus, Istoriju kotarskih uskoka, ali i objaviti kritičko izdanje zadarskog erudita iz 17. stoljeća Šimuna Ljubavca, koje nesumnjivo ima veliku težinu za razumijevanje nastanka modernog pojma Sjeverne Dalmacije, odnosno današnje zadarske subregije. Vladan Desnica je svog strica, $s$ kojim je inače bio u redovitoj prepisci na relaciji Split - Obrovac, kako poticao tako i pomagao da u svojim istraživanjima uspije.

Njihova je suradnja, kao i suradnja sa sve bolesnijim ocem, bila mnogo slabija kada je riječ o književnom stvaralaštvu Vladana Desnice. Nakon 1935. godine, očigledno i pod stričevim utjecajem, odlučuje napustiti svoju namjeru da novelu „Životna staza Jandrije Kutlače" pretvori u roman, s prepoznatljivim regionalnim konotacijama. Neovisno o stričevim željama da nastavi pisati eseje o književnim stvaraocima koji su bitni za razumijevanje kulturne baštine Sjeverne Dalmacije, izgleda da nikada više nije pisao takve eseje.

Kasne 1930-e su i godine njegova intenzivnog prevoditeljskog rada. Iako su Croceovi Eseji iz estetike jedino što je objavio, i to u vlastitoj nakladi u Splitu 1938. godine, iskustva koja je tada stekao bila su poticajna i za njegovo vlastito književno stvaralaštvo, ali i za samoosposobljavanje za poziv koji će mu mnogo težim financijskim prilikama nakon 1950., kada postane slobodni umjetnik, osiguravati sredstva za preživljavanje.

U vremenu koje je lapidarno simbolizirala njegova predratna pjesma „Kišobrani (Ošamućeni građani u predvečerje drugog svjetskog rata)“, Vladan Desnica bio je dezangažirani intelektualac, umjetnik agonije građanskog svijeta. ${ }^{132}$

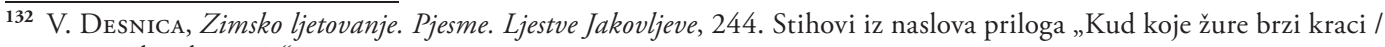
a svi vode u bespuće" preuzeti iz ove pjesme. 


\section{$\cos$}

\section{"WHICHEVER WAY THE QUICK STEPS HURRY AND THEY ALL LEAD TO WASTEland”: Vladan Desnica in SPlit From I935 TO I94I}

Magazin Sjeverne Dalmacije (1934-1935) was a journal project of Vladan Desnica that was long in preparation but a short-lived one. It emerged and disappeared in the shadow of an intensive conflict between his father Dr. Uroš Desnica and Dalmatian vladika (bishop) Dr. Irinej Đorđević. The two of them embodied considerably different political cultures, and even more different political orientations in the crisis situation in Yugoslavia following the murder of the king Aleksandar I Karađorđević. From "A Statement from Northern Dalmatia," published in Split Novo doba on 15 September 1934 and the brochure "Response to 'A Statement from Northern Dalmatia"' by the editorial board of Glas Privredno-kulturne Matice za Sjevernu Dalmaciju (that is, The Blue Book), published in Belgrade in December 1934, to the collection Severna Dalmacija nekad i sad, published in Belgrade in 1939, the conflict did not let up. In effect, it prepared the stage for the drama whose premiere would be in spring 1941, and which would be performed with different ensembles and with changes and additions to the text until the spring of 1945 . Vladan Desnica was directly decried in The Blue Book. He never responded to the accusations that personally affected him considerably. Fragments of his correspondence with his uncle Boško that are preserved testify that he took very hard the public defamation in the affair in which he was necessarily in his father's shadow. New insight into the writer's legacy show that his translation, literary and music activities became much more intensive precisely in that period, as did his dissatisfaction on account of the inevitability of civil service. From his later statements we know that he wrote the first fragments of Proljeća Ivana Galeba in 1936. His key work was conceived as a "response" to his critics, but more than that, it was also conceived already as a radical confrontation with himself. In a time which his poem "Kišobrani (Ošamućeni građani u predvečerje drugog svjetskog rata)" ("Umbrellas (Dazed citizens on the eve of the Second World War)") incisively symbolized, Vladan Desnica was a disengaged intellectual, the artist of an agony of the bourgeois world.

Key words: Vladan Desnica, Split, 1935-1941, literature, historiography, artistic truth, historical truth

\section{$\cos$}

\section{Izvori i literatura}

\section{Izvori}

Osobna ostavština Vladana Desnice (OOVD)

Kut. Prepiska do 1945. I.

Kut. Magazin Sjeverne Dalmacije

Kut. Izdavački ugovori

Kut. Uroš Desnica I.

Kut. Uroš Desnica II. 


\section{Časopisi}

Magazin Sjeverne Dalmacije, 1934. - 1935.

Glasnik Primorske banovine: izdanje Službenog glasnika Primorske banovine, 1938. - 1939.

Rivista Dalmatica, 1899. - 1935.

\section{Literatura}

Josip Andreis - Dragotin Cvetro - Stana Đurić-KLajn, Historijski razvoj muzičke kulture u Jugoslaviji, Zagreb 1962.

Vladan BAJčETA, „Gozba u poljima - fragmenti rekonstrukcije pjesničke knjige Vladana Desnice u rukopisu", Split i Vladan Desnica 1918. - 1945. Zbornik radova sa znanstvenog skupa Desničini susreti 2015. (ur. Drago Roksandić i Ivana Cvijović Javorina ), Zagreb 2016., 459- 482.

Ivanka BešEvić, „Između muzike i literature. Razgovor s književnikom Vladanom Desnicom“, Hotimično iskustvo: diskurzivna proza Vladana Desnice. Knjiga druga (prir. Dušan Marinković), Zagreb 2006., 80-82.

Vitaliano Brunelli, „Giovanni Lucio“, Rivista Dalmatica, anno I., fasc. 10, Zara 1899, 5-24; anno I., fasc. $2^{\circ}$, Zara 1899, 119-139; anno I., fasc. $4^{\circ}$, Zara 1899, 24-51; anno II., fasc. $1^{\circ}$, Zara 1900, 32-52 i anno II., fasc. $4^{\circ}$, Zara 1901, 17-21.

M[iodrag] Bulatović, „Jedan trenutak sa Vladanom Desnicom“, Hotimično iskustvo: diskurzivna proza Vladana Desnice. Knjiga druga (prir. Dušan Marinković), Zagreb 2006., 45-46.

Tommaso Campanella, Grad sunca, Zagreb 1953.

Benedetto Croce, „Čista intuicija i lirski karakter umjetnosti“, Vihor, 2/1938., br. 19, 3.

Benedetto Croce, Eseji iz estetike, Split 1938.

Benedetto Croce, Estetika, Beograd 1934.

Benedetto Croce, Književna kritika kao filozofija, Zagreb 2004.

Benedetto Croce, Storia d'Europa nel secolo decimonono, Bari 1932.

Mirko Deanović - Josip Jernej, Talijansko-hrvatski rječnik, Zagreb 2002.

René Descartes, Rasprava o metodi, Zagreb 1951.

Boško DesnicA, Istorija kotarskih uskoka, sv. 1: 1646 - 1684, Beograd 1950. (ćir.).

Boško Desnica, Istorija kotarskih uskoka, sv. 2: 1684 - 1749, Beograd 1951. (ćir.).

Boško Desnica, Sabrana djela (prir. Milorad Savić), Zagreb 2008. (ćir.).

Boško Desnica, Stojan Janković i uskočka Dalmacija: izabrani radovi (prir. Srđan Volarević), Beograd 1991. (ćir.).

Boško DesNiCA, „Zadranin Šimun Ljubavac. Jedan dalmatinski erudit XVII vijeka“, Glasnik Primorske banovine, 1/1938., br. 1, 173-181.

Vladan Desnica, Zimsko ljetovanje. Pjesme. Ljestve Jakovljeve (= Sabrana djela Vladana Desnice, knj. I, red. Stanko Korać), Zagreb 1974.

Uroš Desnica, „Dr. Dušan Baljak. (In memoriam)“, Magazin Sjeverne Dalmacije, 2/1935., $174-$ 176.

Uroš Desnica, „Jedna sedamdesetgodišnjica. Dr. Božo Peričić“, Novo doba (Split), br. 292, 14. 12. 1935., 6.

[Uroš Desnica, „Komemoracija kralju Aleksandru“], Magazin Sjeverne Dalmacije, 2/1935., 1.

Simeone Gliubich, Dizionario biografico degli uomini illustri della Dalmazia, Vienna - Zara 1856.

Ivan IlLich, „Der gemeine Frieden“, Schlüsseltexte der Friedensforschung/Kea texts of peace studies/ Textos claves de la Investigación para la Paz, (ur. Wolfgang Dietrich i dr.) Münster - Wien 2006., $15-25$. 
„Kako nastaje književno djelo. Razgovor na Književnom petku 26. 10. 1956.“, Hotimično iskustvo: diskurzivna proza Vladana Desnice. Knjiga druga (prir. Dušan Marinković), Zagreb 2006., $153-157$.

Miroslav Kurelac, Ivan Lučić. Otac hrvatske historiografije, Zagreb 1994.

John R. Lampe, Yugoslavia as History. Twice there was a country, Cambridge University Press, 1996.

Dušan Marinković, „Biografija Vladana Desnice“, Hotimično iskustvo: diskurzivna proza Vladana Desnice. Knjiga druga (prir. Dušan Marinković), Zagreb 2006., 217-250.

Dušan Marinković, „Nove spoznaje o Vladanu Desnici“, Ljetopis Dvije hiljade osme (ur. Čedomir Višnjić), Zagreb 2008., 266-284 (ćir.).

Dušan Marinković, „Sudbina jednog opernog libreta. Marginalije oko autorstva Desničinog libreta za Adelovu pjesmu“, Ljetopis Dvije hiljade sedme (ur. Čedomir Višnjić), Zagreb 2007., 248-277 (ćir.).

Jevto M. Milović, „Razgovor s Vladanom Desnicom o umjetničkom stvaranju“, Hotimično iskustvo: diskurzivna proza Vladana Desnice. Knjiga druga (prir. Dušan Marinković), Zagreb 2006., $114-139$.

Grozdana Olujıć, „Pjesnik tuge i nade. Razgovor s Vladanom Desnicom“, Hotimično iskustvo: diskurzivna proza Vladana Desnice. Knjiga druga (prir. Dušan Marinković), Zagreb 2006., 52-54.

Stevo Ostojıć, „Prvu novelu namenio sam 'Politici'“, Hotimično iskustvo: diskurzivna proza Vladana Desnice. Knjiga druga (prir. Dušan Marinković), Zagreb 2006., 105-106.

Vlatko Pavletić, „Svako djelo vrijedi tačno onoliko koliko poetskog sadrži u sebi'“, Hotimično iskustvo: diskurzivna proza Vladana Desnice. Knjiga druga (prir. Dušan Marinković), Zagreb 2006., 58-74.

Bogdan Radica, Živjeti nedoživjeti, knj. 1: Uspomene hrvatskog intelektualca kroz moralnu i ideološku krizu Zapada, München - Barcelona 1982.

Drago Roksandić, „Boško Desnica - Vladanu Desnici. Izbor pisama iz Osobne ostavštine (1933. - 1938.) Vladana Desnice“, u: Ljetopis Dvijehiljadepetnaeste godine, Zagreb 2015., 374.

Drago Roksandić, „Dr. Uroš Desnica 1918. - 1921.: životopisne nedoumice na raskrižju epohâ“, Spalatumque dedit ortum. Zbornik povodom desete godišnjice Odsjeka za povijest Filozofskog fakulteta u Splitu (ur. Ivan Basić i Marko Rimac), Split 2014., 499-511.

Drago Roksandić, „Književnik, književni opus i mogućnosti historiografskih interpretacija. Pokušaj 'egohistorije’ Vladana Desnice“, Književna republika, 4/2006., br. 3-4, 13-24.

Drago Roksandić, „O Vladanu Desnici i 'Desničinim susretima'“, Desničini susreti 2005. - 2008. Zbornik radova (ur. Drago Roksandić i Ivana Cvijović Javorina), Zagreb 2010., 255-282.

Drago RoKsAndić, „...Pisac uvijek ima upravo onoliku slobodu stvaranja koliku sam sebi dozvoli...' Civilna kultura Vladana Desnice poslije 1945. godine“, Desničini susreti 2010. Zbornik radova (ur. Drago Roksandić i Ivana Cvijović Javorina), Zagreb 2011., 24-25.

Drago Roksandić, „Ratni dani Vladana Desnice“, Intelektualci i rat 1939. - 1947. Zbornik radova s medunarodnog skupa Desničini susreti 2012. (ur. Drago Roksandić i Ivana Cvijović Javorina), sv. 2, Zagreb 2013., 529-555.

Drago Roksandić, „Vladan Desnica i Magazin Sjeverne Dalmacije: književnik i (ne)moć tradicije“, Vladan Desnica i Split 1920. - 1945. Zbornik radova sa znanstvenog skupa Desničini susreti 2014. (ur. Drago Roksandić i Ivana Cvijović Javorina), Zagreb 2015., 181-234.

Matija Sinko, Bakrorezi Martina Engelbrechta iz Nasljednoga rata: historijsko-imagološka analiza, diplomski rad, Diplomski studij Odsjeka za povijest Filozofskog fakulteta Sveučilišta u Zagrebu, Zagreb 2012.

Š[ime] V[uČEtıć], „G. Vladan Desnica prevađa B. Crocea“, Naši dani. List za kulturna pitanja i književnost (ur. Marin Franičević), 1/1938., br. 1, 29-31. 
Umberto Urbani, La Jugoslavia e i suoi banati, Trieste 1935.

Umberto Urbani, Scrittori Jugoslavi, sv. 2, Zara 1935.

Ana M. ZečEvić, „Muzičko stvaralaštvo Vladana Desnice“, Ljetopis Dvije hiljade osme (ur. Čedomir Višnjić), Zagreb 2008., 285-312 (ćir.).

Prilog $I$.

\section{BOgdAN RADICA - ĆIRI ČIČIN-ŠAJINU, GÉNÈVE, 9. RUJNA I938. ${ }^{133}$}

Ženeva, 9 septembra 1938

Dragi Ćiro, kako sam Vam kazao bio sam kod Crocea. Kazao sam mu, da je u Splitu izišao prijevod njegovih Eseja iz estetike. Croce me je zamolio da mu nabavim dva (2) primjerka. Molim Vas da kažete g. Desnici, da mi pošlje 2 primjerka, kako bih mogao da ih pošljem g. Croceu. Ali odmah. Ako Vam on ne da, onda ću ih ja poručiti kod Marpurga. Ali molim Vas da me svakako izvijestite, da ne bi uzaludno naručivao. Molim Vas, da to bude odmah.

Sa najsrdačnijim pozdravima Vama odani

Bogdan Radica

Monsieur / Ćiro Čičin-Šajin / Radakcija „Novo Doba“ / Split / Yougoslavie

Adresa: Bogdan Radica / 11, rue de Beaumont, 11 / Génève / (Suisse) 


\section{Prilog II.}

\section{Bogdan Radica - Vladanu Desnici, GÉNÈvE, I7. RUJNA I938. ${ }^{\mathrm{I} 34}$}

Poštovani Gospodine,

Primio sam danas dva primerka Vašeg prevoda Croceovih Eseja iz estetike i Vaše pismo.

Najtoplija hvala.

G. Croce me je zamolio, pre nekoliko dana, da mu pošljem za njegovu biblioteku, što sam učinio danas, priloživši mu i prevod naslova prevedenih eseja.

Šteta, da niste preveli ceo Brevijar Estetike: bila bi to celina, iako je predavanje u Heidelbergu od 1908. važan i bitan datum u razvoju Croceove estetike.

Ovih dana izišla je La Storia come pensiero e come azione, o kojoj ću pisati. Vrlo je interesantna i neobično aktuelna. Croce koncentriše u Istoriji sav vrhunac svoje misli.

Što mi pišete o Istoriji Europe, ona je prevedena i objavljena na slovenački. Čudi me što je Svemir Lazarević ne će da objavi. On je moj dobar prijatelj i ja ću mu pisati prvom zgodom. Bilo bi korisno, da se ta stvar objavi kod nas. Mogli bi, možda, i Vi sami da iskušate jednom dobrom reklamom, ili, možda, obratite se g. Anti Velzeku, direktoru „Binoza - Svjetski Pisci“ Zagreb, Bulićeva ul. 12? Ja mislim, da bi on mogao da to objavi u svojoj Biblioteci Političkih pisaca, gde je objavio i Carla Sforzu. Pišite mu i od moje strane.

Izvolite, poštovani gospodine, primiti osećaje moje zahvalnosti, sa iskrenim pozdravom Vaš Bogdan Radica

Monsieur / Vladan Desnica / Split / (Yougoslavie)

Exp. Bogdan Radica / 11, r. de Beaumont / Genève 